\title{
In Vitro Cytological Responses against Laser Photobiomodulation for Periodontal Regeneration
}

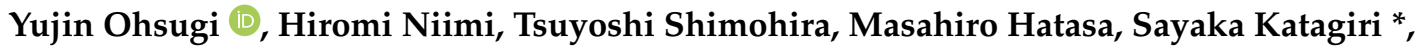 \\ Akira Aoki and Takanori Iwata * (D) \\ Department of Periodontology, Graduate School of Medical and Dental Sciences, Tokyo Medical and Dental \\ University (TMDU), Tokyo 113-8510, Japan; ohsugi.peri@tmd.ac.jp (Y.O.); kawakami.peri@tmd.ac.jp (H.N.); \\ shimohira.peri@tmd.ac.jp (T.S.); hatasa.peri@tmd.ac.jp (M.H.); aoperi@tmd.ac.jp (A.A.) \\ * Correspondence: katagiri.peri@tmd.ac.jp (S.K.); iwata.peri@tmd.ac.jp (T.I.); Tel.: +81-3-5803-5488 (S.K. \& T.I.)
}

Received: 10 November 2020; Accepted: 21 November 2020; Published: 26 November 2020

\begin{abstract}
Periodontal disease is a chronic inflammatory disease caused by periodontal bacteria. Recently, periodontal phototherapy, treatment using various types of lasers, has attracted attention. Photobiomodulation, the biological effect of low-power laser irradiation, has been widely studied. Although many types of lasers are applied in periodontal phototherapy, molecular biological effects of laser irradiation on cells in periodontal tissues are unclear. Here, we have summarized the molecular biological effects of diode, Nd:YAG, Er:YAG, Er,Cr:YSGG, and $\mathrm{CO}_{2}$ lasers irradiation on cells in periodontal tissues. Photobiomodulation by laser irradiation enhanced cell proliferation and calcification in osteoblasts with altering gene expression. Positive effects were observed in fibroblasts on the proliferation, migration, and secretion of chemokines/cytokines. Laser irradiation suppressed gene expression related to inflammation in osteoblasts, fibroblasts, human periodontal ligament cells (hPDLCs), and endothelial cells. Furthermore, recent studies have revealed that laser irradiation affects cell differentiation in hPDLCs and stem cells. Additionally, some studies have also investigated the effects of laser irradiation on endothelial cells, cementoblasts, epithelial cells, osteoclasts, and osteocytes. The appropriate irradiation power was different for each laser apparatus and targeted cells. Thus, through this review, we tried to shed light on basic research that would ultimately lead to clinical application of periodontal phototherapy in the future.
\end{abstract}

Keywords: lasers; periodontal tissue; photobiomodulation; cell proliferation; gene expression

\section{Introduction}

Periodontal tissue consists of "gingiva, periodontal ligament, cementum, and alveolar bone" [1]. Periodontal diseases cause a wide range of inflammatory conditions that affect the periodontal tissue, which could lead to loss of teeth and contribute to systemic inflammation [2]. Basic periodontal therapy eliminates etiological factors for periodontal disease and relieves inflammation in periodontal tissues [3]. Recently, periodontal therapy using a laser, "periodontal phototherapy," has attracted much attention [4]. Many reports have been published on the methods recommended for periodontal therapy using lasers [5,6]. In addition, laser irradiation is also applied to treat pressure ulcers [7] and pain associated with temporomandibular dysfunction [8]. However, basic research related to clinical research is inadequate. We propose that it is necessary to understand the molecular biological effects of periodontal phototherapy for periodontal therapy. Photobiomodulation (PBM) is a treatment method based on research findings suggesting that irradiation with specific wavelengths of red or infrared light produces a wide range of physiological effects in cells, tissues, animals, and humans [9]. A previous study reported that the effect was a nonthermal process involving endogenous chromophores eliciting 
photophysical and photochemical phenomena at various biological scales, resulting in beneficial therapeutic outcomes [10].

The purpose of this review was to investigate cytological responses against laser irradiation for periodontal regeneration. We tried to provide insights on basic research that would subsequently lead to clinical research on periodontal phototherapy in the future.

\section{Interaction with Tissues}

When laser energy reaches a tissue surface, it can be reflected, scattered, absorbed, or transmitted to the surrounding tissues. The performance of a laser is determined by the degree of absorption. In particular, absorption in biological tissues is strongly influenced by the absorption coefficient in water, which is inherent to each wavelength $[11,12]$. Thus, lasers are clinically classified into two types depending on their wavelength: (1) a deeply penetrating type where the laser light penetrates and scatters into the tissue more deeply, such as the neodymium-doped yttrium-aluminum-garnet (Nd:YAG) $(1064 \mathrm{~nm})$ and diode lasers (810-980 nm available for clinical application and (2) a superficially absorbed type (shallowly penetrating type) where the laser light is absorbed in the superficial layer and does not penetrate or scatter deeply, such as the carbon dioxide $\left(\mathrm{CO}_{2}\right)(10,600 \mathrm{~nm})$, erbium-doped yttrium-aluminum-garnet (Er:YAG) $(2940 \mathrm{~nm})$, and erbium, chromium: yttrium -scandium-gallium-garnet (Er,Cr:YSGG) $(2780 \mathrm{~nm})$ lasers [4,13].

\section{Effects of Laser Irradiation on Osteoblasts}

The number of reports about the effects of laser irradiation on osteoblasts is increasing. For periodontal regeneration, osteoblasts play essential roles in bone formation and remodeling [14]. Therefore, the laser irradiation of osteoblasts is an important focus of research.

Most reports on laser-irradiated osteoblasts in vitro used diode lasers, including a blue diode laser $(\lambda=450 \mathrm{~nm})$, a red diode laser $(\lambda=635-660 \mathrm{~nm})$, and a Ga-Al-As laser $(\lambda=780-980 \mathrm{~nm})$. Several studies have reported the effects of the Nd:YAG laser $(\lambda=1064 \mathrm{~nm})$ on osteoblasts in vitro. A few reports on the effects of $\mathrm{CO}_{2}$ and Er:YAG lasers $(\lambda=2940 \mathrm{~nm})$ have been published.

\subsection{Diode Lasers}

Various kinds of osteoblasts or osteoblast-like cells were used in previous studies to assess the effects of diode lasers. Most studies used cell lines such as MC3T3-E1 cells, an osteoblastic cell line derived from mouse, in 12 reports [15-26]. The effects of laser irradiation on Saos-2 [27-34], MG-63 [17,35-40], and human osteoblastic cell lines [32,41-47] were investigated in 8, 7, and 8 studies, respectively. In addition, primary osteoblasts from rat calvaria or human bone were also used in 8 and 5 studies, respectively.

Many studies have reported on the proliferation of cells irradiated by diode lasers. Diode laser irradiation significantly increased cell proliferation 1-3 days after irradiation [17,20,21,24-26,28,29,33,34,42,48-51]. Most of the effective energy density (fluence) ranges were from 1 to $10 \mathrm{~J} / \mathrm{cm}^{2}$. In a previous study, irradiation at a total energy of $45.9-137.6 \mathrm{~J} / \mathrm{cm}^{2}$ significantly increased the proliferation of human fetal osteoblasts (hFOB 1.19) [42]. Laser irradiation using various fluences (0.48-3.84, 5.0-8.3, and $45.9-137.6 \mathrm{~J} / \mathrm{cm}^{2}$ ) also significantly enhanced cell proliferation at a later period of observation (e.g., on day 4-12) [29,42,48,52-56]. The proliferation of hypoxic-cultured osteoblasts was increased at 24 and $72 \mathrm{~h}$ after irradiation at 1.2 and $3.6 \mathrm{~J} / \mathrm{cm}^{2}$, respectively [41]. In contrast, diode laser irradiation at similar fluences did not show a significant increase in osteoblast proliferation in some studies $[17,27,35,38,57,58]$. However, fluorescence-activated cell sorting (FACS) analysis of the cell cycle revealed that the percentage of cells in $\mathrm{G}_{2} / \mathrm{M}$ phase was significantly greater in rat calvarial osteoblastic cells by diode laser irradiation at $3.8 \mathrm{~J} / \mathrm{cm}^{2}$ at $12 \mathrm{~h}$ after irradiation compared to nonirradiated control cells [49]. Cell viability and migration have also been evaluated in many studies. They were significantly increased by irradiation at $0.5-12 \mathrm{~J} / \mathrm{cm}^{2}[30,32,36,43-45,47,56,59,60]$ Irradiation at fluences greater than $20 \mathrm{~J} / \mathrm{cm}^{2}$ significantly decreased cell viability [30]. Previously, in most studies, it has been reported that 
diode laser irradiation at 1-12 $\mathrm{J} / \mathrm{cm}^{2}$ tended to enhance the proliferation and viability of osteoblasts. However, effective irradiation protocols of diode lasers on the migration of osteoblasts have not been specifically determined.

Calcification of osteoblasts promoted by diode laser irradiation at $0.4-8.3 \mathrm{~J} / \mathrm{cm}^{2}$ has been demonstrated in several studies [23,26,29,33,35,46,49,50,52-54,56,59,61-63]. Significantly enhanced mineralization in osteoblasts was observed at 7 days at the earliest [23], and in many cases, at around 20 days after irradiation [26,33,35,49,52-54,56,59,63]. Both single irradiation and multiple irradiations significantly promoted the calcification of osteoblasts.

Diode laser irradiation has been reported to affect gene and protein expression related to osteogenic differentiation, including alkaline phosphatase (ALP), osteocalcin, type I collagen, Runt-related protein transcription factor 2 (Runx2), osterix, bone morphogenetic proteins (BMPs), transforming growth factor- $\beta 1$ and $\beta 2$ (TGF- $\beta 1$ and $\beta 2$ ), osteopontin, receptor activator of NF- $\mathrm{kB}$ ligand (RANKL), and osteoprotegerin (OPG).

At 1-14 days after irradiation, mRNA expression of ALP was significantly increased by irradiation at $0.4-6.7 \mathrm{~J} / \mathrm{cm}^{2}[26,33,35,39,40,46,54,57]$. ALP activity was also significantly enhanced at day $1-18$ after irradiation at $1-10 \mathrm{~J} / \mathrm{cm}^{2}$ in a number of studies $[17,22,23,26,28,29,37,46,49,52,53,56,62,64]$. Meanwhile, a previous study revealed that irradiation at $2 \mathrm{~J} / \mathrm{cm}^{2}$ significantly decreased ALP activity in osteoblasts at 48 and $72 \mathrm{~h} \mathrm{[34].} \mathrm{Some} \mathrm{studies} \mathrm{have} \mathrm{reported} \mathrm{that} \mathrm{diode} \mathrm{laser} \mathrm{irradiation} \mathrm{did} \mathrm{not} \mathrm{increase} \mathrm{ALP}$ activity of primary osteoblasts after irradiation at 1.5 or $3 \mathrm{~J} / \mathrm{cm}^{2}[57,58]$.

Osteocalcin, a marker of osteoblast terminal differentiation [65], has been investigated in relation to calcification of osteoblasts by diode laser irradiation. Ozawa et al. [52] reported that $830 \mathrm{~nm}$ diode irradiation at $3.8 \mathrm{~J} / \mathrm{cm}^{2}$ on day 1 significantly increased the number of osteocalcin mRNA-positive cells and cell masses on day 2 and 4, respectively. Moreover, diode laser irradiation at $3 \mathrm{~J} / \mathrm{cm}^{2}$ significantly enhanced osteocalcin synthesis in primary human osteoblast-like cells cultured on titanium implant material on day 10 [55]. Osteocalcin activity in hFOB 1.19 was significantly increased at 7 days after $940 \mathrm{~nm}$ laser irradiation at considerably high fluences in the range of $22.9-137.6 \mathrm{~J} / \mathrm{cm}^{2}$ [42]. Even in hypoxic-cultured human osteoblasts, mRNA Bglap was increased on day 1-3 by diode laser irradiation at 1.2-3.6 J/ $\mathrm{cm}^{2}$ [41]. The expression of Bglap on day 14 was significantly decreased in a human osteoblast cell line irradiated at $0.5,1$, and $2 \mathrm{~J} / \mathrm{cm}^{2}$ [45]; however, indocyanine green (ICG)-mediated PBM significantly increased Bglap expression on day 7 following irradiation at $0.5 \mathrm{~J} / \mathrm{cm}^{2}$ [46]. ICG-mediated PBM is a PBM with a photosensitizer, a light-activated molecule, and shares similar mechanisms with photodynamic therapy [46]. The effects of diode laser irradiation on osteoblasts have been investigated in the expression of type I collagen [31,34,35,40,41,45-47]. Most reports have shown that low-level irradiation at $0.5-3.6 \mathrm{~J} / \mathrm{cm}^{2}$ significantly increased type I collagen expression in human osteoblastic cells at 1-20 days after irradiation [34,35,40,41,45-47]. Irradiation at higher fluences (5 and $\left.15 \mathrm{~J} / \mathrm{cm}^{2}\right)$ also significantly increased Col1a1 expression at 24,48 , and $72 \mathrm{~h}$ in a previous study [31]. Irradiation at $1.2-3.6 \mathrm{~J} / \mathrm{cm}^{2}$ significantly increased the mRNA expression of type I collagen in hFOB 1.19 at $24 \mathrm{~h}$ after irradiation compared to that in hypoxic-cultured osteoblasts. However, at 48 and $72 \mathrm{~h}$, type I collagen mRNA expression was significantly lower than that in hypoxic-cultured osteoblasts upon irradiation [41].

Several studies have reported the effect of diode laser irradiation on the expression of Runx2, an essential transcription factor for osteoblast differentiation $[18,26,33,57,62,66]$. Laser irradiation at $808 \mathrm{~nm}$ and $0.4 \mathrm{~J} / \mathrm{cm}^{2}$ at continuous wave mode and $1.9 \mathrm{~J} / \mathrm{cm}^{2}$ of $2 \mathrm{~Hz}$ pulsed mode at $830 \mathrm{~nm}$ significantly increased the expression of Runx2 [18,33]. Ultrahigh-frequency and ultrashort-pulse $405 \mathrm{~nm}$ blue laser irradiation at $5.6 \mathrm{~J} / \mathrm{cm}^{2}$ on osteoblasts significantly increased Runx2 expression on day 3 in MC3T3-E1 cells [26]. Some reports showed that irradiation at $3 \mathrm{~J} / \mathrm{cm}^{2}$ decreased Runx2 expression in primary human osteoblast-like cells from alveolar bone [57,62].

Osterix is generally required for Bglap activation and bone formation [67] and is mutually regulated with Runx2 for the proliferation and differentiation of osteoblast-lineage cells and their progenitors [66]. Irradiation at $1.9-5.9 \mathrm{~J} / \mathrm{cm}^{2}$ significantly increased the expression of $O s x$ at $9 \mathrm{~h}$ on day 
3 in osteoblasts $[18,23,26,64]$. In contrast, downregulation of $O s x$ at 3,6 , and $12 \mathrm{~h}$ in primary human osteoblast-like cells from the alveolar bone after irradiation at $3 \mathrm{~J} / \mathrm{cm}^{2}$ was reported [62].

BMPs, factors for bone formation, induce various genes, including Runx2 and Osterix (Sp7) [68]. The effects of diode laser irradiation on BMP expression in osteoblasts have been studied previously $[18,35,40,41,47,57]$. The expression of $B m p 2, B m p 4$, and $B m p 7$ was significantly increased at 6,9 , and $12 \mathrm{~h}$ after irradiation at $0.9-2.8 \mathrm{~J} / \mathrm{cm}^{2}$ in MC3T3-E1 cells [18]. At later time points, on day 1-20, BMP mRNA expression was also significantly increased by irradiation at $1.2-6.7 \mathrm{~J} / \mathrm{cm}^{2}[35,40,41]$. Regarding bisphosphonate (BP)-related osteonecrosis of the jaw, a combined application of rhBMP-2 and irradiation at $1.2 \mathrm{~J} / \mathrm{cm}^{2}$ was more effective in enhancing osteoblastic activity and bone formation activity in alendronate-treated hFOB 1.19 than the application of either modality alone [47].

BMPs belong to the TGF- $\beta$ family, which is a prototype of a large family of cytokines involved in the growth and remodeling of bone [69]. TGF- $\beta 1$ mRNA expression in osteoblasts was significantly increased at day $1-3,10$, and 20 after irradiation at $1.2-6.7 \mathrm{~J} / \mathrm{cm}^{2}[35,40,41]$. Laser irradiation at $830 \mathrm{~nm}$ and $3 \mathrm{~J} / \mathrm{cm}^{2}$ significantly promoted TGF- $\beta 1$ production, as measured by an enzyme-linked immunosorbent assay [55]. The expression of TGF- $\beta 1$ suppressed by alendronate was recovered following a combined application of rhBMP-2 and irradiation at $1.2 \mathrm{~J} / \mathrm{cm}^{2}$ in hFOB1.19 cells [47]. However, irradiation at 5-10 J/ $/ \mathrm{cm}^{2}$ significantly decreased the expression of TGFB1 in Saos-2 cells at 48 and $72 \mathrm{~h} \mathrm{[31].}$

Several previous studies have reported the expression of osteopontin [33,34,47,57]. Osteopontin, a bone matrix noncollagenous glycophosphoprotein, is secreted by osteoblasts during bone mineralization and remodeling [70]. Tani et al. [33] reported that red diode laser irradiation at $0.4 \mathrm{~J} / \mathrm{cm}^{2}(\lambda=635 \mathrm{~nm})$ significantly increased osteopontin expression by densitometric analysis of the fluorescence intensity of immunostained osteopontin. Another study indicated that $808 \mathrm{~nm}$ laser irradiation at $1.2 \mathrm{~J} / \mathrm{cm}^{2}$ had a greater effect on osteopontin expression in alendronate-treated hFOB 1.19 cells than in rhBMP-treated cells by Western blotting analysis [47]. However, $670 \mathrm{~nm}$ laser irradiation at $2 \mathrm{~J} / \mathrm{cm}^{2}$ significantly decreased osteopontin mRNA expression in Saos- 2 cells at $24 \mathrm{~h}$ compared to cells irradiated at $1 \mathrm{~J} / \mathrm{cm}^{2}$ [34]. Irradiation at $3 \mathrm{~J} / \mathrm{cm}^{2}$ also decreased osteopontin mRNA expression in primary human osteoblast-like cells at 14 days [57].

To investigate the effects of diode laser irradiation on bone remodeling, osteoclast-related markers (e.g., RANKL and OPG) have been studied [30,44,47,51,57]. A previous study reported a significant downregulation of RANKL, a significant upregulation of OPG, and a significant decrease in the RANKL/OPG ratio in primary rat calvarial cells irradiated at $1.1 \mathrm{~J} / \mathrm{cm}^{2}$ [51], whereas irradiation with a dose of $3 \mathrm{~J} / \mathrm{cm}^{2}$ increased the RANKL/OPG ratio in primary human osteoblast-like cells on titanium disks [57]. Irradiation at 5,10 , and $50 \mathrm{~J} / \mathrm{cm}^{2}$ tended to increase the RANKL/OPG ratio, but no significant differences were observed [30]. Ga-Al-As laser irradiation with 808 or $920 \mathrm{~nm}$ at $1.2 \mathrm{~J} / \mathrm{cm}^{2}$ increased RANKL and OPG expression in hFOB 1.19 cells [44,47].

Other factors related to bone formation are affected by diode laser irradiation. Smad1/5/8, which are activated by BMPs and referred to as BMP-specific receptor-regulated Smads [68,71], exhibited significantly enhanced phosphorylation by $805 \mathrm{~nm}$ laser irradiation at $5.9 \mathrm{~J} / \mathrm{cm}^{2}$ [64]. The expression of phospho-extracellular signal-regulated kinase (ERK) was significantly increased by irradiation at 5 and $10 \mathrm{~J} / \mathrm{cm}^{2}$ [36], and phosphorylated ERK1/2 was also increased at $15 \mathrm{~min}$ after irradiation at $2.9 \mathrm{~J} / \mathrm{cm}^{2}$ [25]. The expression of distal-less homeobox 5 (Dlx5), which stimulates osteoblast differentiation [72], and Msh homeobox 2 (Msx2), which promotes osteoprogenitor proliferation but prevents differentiation, was significantly enhanced by irradiation at $1.9 \mathrm{~J} / \mathrm{cm}^{2}$ in MC3T3-E1 cells [18]. Diode laser irradiation at $7.6 \mathrm{~J} / \mathrm{cm}^{2}$ significantly increased osteoglycin gene expression at $2 \mathrm{~h}$ after irradiation [16]. Osteoglycin was reported to increase osteoblast differentiation in some studies [73], whereas other studies reported that osteoglycin decreases osteoblast differentiation [74]. 


\subsection{Nd:YAG Laser}

Nd:YAG laser is the second-most studied laser for its effect on osteoblasts or osteoblast-like cells after diode lasers. The effects of Nd:YAG laser on Saos-2 human osteoblast-like cells have been investigated in many studies [75-79]. Nd:YAG laser irradiation has been reported to have positive effects on osteoblasts or osteoblast-like cells. Irradiation at $10 \mathrm{~Hz}$ and $20 \mathrm{~mJ}$ for $10 \mathrm{~s}$ had a stimulatory effect on the cell viability and proliferation of Saos-2 cells at 7, 14, and 21 days [75]. Cell proliferation of Saos-2 was also significantly increased at $48 \mathrm{~h}$ following irradiation at 50 or $70 \mathrm{~Hz}$ and $20 \mathrm{~mJ} /$ pulse for $10 \mathrm{~s}$ [76]. Another study reported that irradiation 3 times at $0.5-2 \mathrm{~W}$ enhanced cell proliferation rates of Saos- 2 cells on day 4 compared to one-time irradiation [77]. Irradiation at $10.3 \mathrm{~J} / \mathrm{cm}^{2}$ accelerated cell migration until $24 \mathrm{~h}$ after irradiation and significantly enhanced ATP production in Saos- 2 cells at $24 \mathrm{~h}$ following irradiation [78]. However, a Q-switched Nd:YAG laser irradiation at 1.5, 3, or $5 \mathrm{~J} / \mathrm{cm}^{2}$ significantly decreased proliferation in MC3T3-E1 cells [80].

Nd: YAG laser irradiation showed various effects regarding gene and protein expression related to osteogenic differentiation or bone remodeling. ALP activity was significantly increased in MC3T3-E1 cells at 3,7 , and 14 days after irradiation at $1.5,3$, or $5 \mathrm{~J} / \mathrm{cm}^{2}$, with or without nonglycosylated human recombinant BMP-2 $(100 \mathrm{ng} / \mathrm{mL})$ treatment [80]. ALP gene (Alpl) expression was significantly increased in Saos-2 cells at $24 \mathrm{~h}$ and 7 days after irradiation at 17.3 and $1.5 \mathrm{~J} / \mathrm{cm}^{2}$, respectively $[76,79]$. An increase in Runx 2 and osteopontin mRNA expression was also significantly induced at 7 days after irradiation at $1.5 \mathrm{~J} / \mathrm{cm}^{2}$ in Saos-2 cells [76]. Expression of BMP2 was significantly increased in MC3T3-E1 cells 2 days after irradiation at $3 \mathrm{~J} / \mathrm{cm}^{2}$ [80]. Irradiation at $17.3 \mathrm{~J} / \mathrm{cm}^{2}$ significantly increased mRNA expression of RANKL and OPG in Saos-2 cells at $24 \mathrm{~h}$ [79]. In a previous study, highly intensified calcium deposition on day 12 and significantly enhanced mineralization on day 21 were observed in MC3T3-E1 cells by Nd:YAG laser irradiation at $1.5-5 \mathrm{~J} / \mathrm{cm}^{2}$ with or without rhBMP-2 treatment [80]. In addition, intracellular $\mathrm{Ca}^{2+}$ in Saos-2 cells was increased by irradiation at $50 \mathrm{~Hz}$ with a fluence of $1.5 \mathrm{~J} / \mathrm{cm}^{2}$ through the activation of the transient receptor potential 1 (TRPC1) ion channels [76]. Gene expression of insulin-like growth factor-1 (IGF-1; IGF1), an important regulator of bone formation [81], was significantly enhanced in MC3T3-E1 cells on day 2 after irradiation at $3 \mathrm{~J} / \mathrm{cm}^{2}$ with or without rhBMP-2 treatment [80].

\subsection{Er:YAG Laser}

Three previous studies reported the effects of Er:YAG laser irradiation on osteoblasts or osteoblast-like cells in vitro [82-84]. Er:YAG laser irradiation at $5.1-12.7 \mathrm{~J} / \mathrm{cm}^{2}$ significantly reduced mitochondrial activity in Saos-2 cells compared to nonirradiated cells. However, mitochondrial activity was significantly increased with decreasing energy settings and/or increasing the distance between the laser application tip and the bottom of the culture plate [82]. Er:YAG laser irradiation at a fluence of 1.0-4.3 J/ $\mathrm{cm}^{2}$ significantly increased MC3T3-E1 cell proliferation by irradiation in the absence of a culture medium. When irradiated at higher fluences $\left(6.7\right.$ and $\left.8.6 \mathrm{~J} / \mathrm{cm}^{2}\right)$, cell cytotoxicity of MC3T3-E1 was significantly increased. In the presence of a culture medium during irradiation, Er:YAG laser irradiation at much higher fluences (12.9 and $\left.15.1 \mathrm{~J} / \mathrm{cm}^{2}\right)$ significantly increased MC3T3-E1 cell proliferation on day 1 and 3 without increasing cell cytotoxicity. The effect of Er:YAG laser on cell proliferation seemed to be induced by the activation of ERK [83], which plays a central role in the control of cell proliferation [85]. Another study reported that Er:YAG laser irradiation did not affect cell proliferation but significantly enhanced calcification of primary osteoblast-like cells from rat calvaria [84]. Irradiation at $3.3 \mathrm{~J} / \mathrm{cm}^{2}$ significantly promoted mineralization of primary osteoblast-like cells on day 7, possibly via enhanced Bglap expression, without major thermal effects. Microarray analysis revealed that irradiation at $3.3 \mathrm{~J} / \mathrm{cm}^{2}$ caused an upregulation of inflammation-related genes and downregulation of Wisp2, which plays an important role in the differentiation and mineralization of osteoblasts [86]. Gene set enrichment analysis showed that Er:YAG laser irradiation enriched Notch signaling, which plays a critical role in various cellular functions, including the promotion of osteogenic differentiation of osteoblasts in synergy with BMP [87]. 


\subsection{Er,Cr:YSGG Laser}

There are no reports on the direct effects of Er,Cr:YSGG laser irradiation on osteoblasts or osteoblast-like cells. Hence, the molecular biological effects of Er,Cr:YSGG laser irradiation on osteoblasts remains unclear.

\section{5. $\mathrm{CO}_{2}$ Laser}

The effect of $\mathrm{CO}_{2}$ laser irradiation on osteoblast-like cells was reported in a previous study [88]. The study investigated the effect of $\mathrm{CO}_{2}$ laser irradiation on rat osteoblast-like ROS 17/2.8 cells at $0.5-2 \mathrm{~W}$ for $20 \mathrm{~s}$, resulting in a power density of $0.4-1.43 \mathrm{~J} / \mathrm{cm}^{2} . \mathrm{CO}_{2}$ laser irradiation at $1.43 \mathrm{~J} / \mathrm{cm}^{2}$ enhanced the mRNA expression of bone sialoprotein (BSP) at $12 \mathrm{~h}$ after irradiation. Transcription of BSP (IBSP) gene was also enhanced via the tyrosine kinase, Src tyrosine kinase, and ERK 1/2 signaling pathways, and fibroblast growth factor 2 response element in the rat IBSP gene promoter by $\mathrm{CO}_{2}$ laser irradiation.

\subsection{Summary}

The contents of this section are summarized in Table 1. Several reports have revealed the favorable effects of laser irradiation on osteoblasts or osteoblast-like cells. Laser irradiation enhances or increases cell proliferation, viability, migration, calcification, and expression of genes and proteins related to osteogenic differentiation, thereby promoting bone formation. These effects were observed in many studies using various types of lasers with different wavelengths; however, most of the effective energy fluences were low (under $6.0 \mathrm{~J} / \mathrm{cm}^{2}$ ). In some studies, high power as well as low power irradiation was reported to have biological effects on osteoblasts or osteoblast-like cells. However, in vitro evidence related to Nd:YAG, $\mathrm{CO}_{2}$, Er:YAG, and Er,Cr:YSGG lasers are still limited. Further research is needed to elucidate the molecular biological effects of laser irradiation on osteoblasts.

\section{Effects of Laser Irradiation on Fibroblasts}

Fibroblasts are components of the connective tissue, which migrate to a lesion from the late inflammatory phase until epithelialization is completed [89]. Fibroblasts play an essential role in supporting other cells, are associated with wound healing or regeneration, and function to break down blood clots, thereby secreting various growth factors and cytokines and creating new extracellular matrix (ECM) and collagen structures [90]. Additionally, fibroblasts play a critical role in wound contraction [91]. Therefore, fibroblasts are essential for effective wound healing and tissue regeneration.

Since various types of lasers have been shown to enhance wound healing through tissue repair and anti-inflammatory effects in previous studies [92,93], the biological and molecular mechanism of this event has been pursued over the years. In particular, the effect of lasers on fibroblasts has been focused on this field. In this section, we focus on gingival fibroblasts. 
Table 1. Summary of the effects of laser irradiation on osteoblasts.

\begin{tabular}{|c|c|c|c|c|c|}
\hline Reference No. & Laser & Cell & Year Author & Irradiation Protocol & Major Findings \\
\hline [15] & Diode & MC3T3-E1 & $\begin{array}{c}2001 \\
\text { Yamamoto, et al. }\end{array}$ & $\begin{array}{l}830 \mathrm{~nm} \\
7.64 \mathrm{~J} / \mathrm{cm}^{2} \\
\mathrm{CW} \\
20 \mathrm{~min} \\
830 \mathrm{~nm}\end{array}$ & $\begin{array}{l}\text { Irradiation may enhance DNA replication and play a } \\
\text { role in stimulating proliferation of osteoblast through } \\
\text { the enhancement of the mouse minichromosome } \\
\text { maintenance } 3 \text { gene expression. }\end{array}$ \\
\hline [16] & Diode & MC3T3-E1 & $\begin{array}{c}2003 \\
\text { Hamajima et al. }\end{array}$ & $\begin{array}{l}7.64 \mathrm{~J} / \mathrm{cm}^{2} \\
\mathrm{CW} \\
20 \mathrm{~min}\end{array}$ & $\begin{array}{c}\text { The osteoglycin gene was upregulated at } 2 \mathrm{~h} \text { after low } \\
\text { level laser irradiation. }\end{array}$ \\
\hline [17] & Diode & MC3T3-E1, MG-63 & $\begin{array}{l}2007 \\
\text { Renno, et al. }\end{array}$ & $\begin{array}{l}670,780, \text { or } 830 \mathrm{~nm} \\
0.5,1,5, \text { or } 10 \mathrm{~J} / \mathrm{cm}^{2} \\
\mathrm{CW}\end{array}$ & $\begin{array}{l}\text { Osteoblast proliferation increased significantly after } \\
830 \mathrm{~nm} \text { laser irradiation }\left(10 \mathrm{~J} / \mathrm{cm}^{2}\right) \text { but decreased after } \\
780 \mathrm{~nm} \text { laser irradiation }\left(\text { at } 1,5 \text {, and } 10 \mathrm{~J} / \mathrm{cm}^{2}\right) \text {. } \\
\text { MG- } 63 \text { cell proliferation increased significantly after } \\
670 \mathrm{~nm}\left(\text { at } 5 \mathrm{~J} / \mathrm{cm}^{2}\right) \text { and } 780 \mathrm{~nm} \text { (at } 1,5 \text {, and } 10 \mathrm{~J} / \mathrm{cm}^{2} \text { ) } \\
\text { laser irradiation, but not after } 830 \mathrm{~nm} \text { laser irradiation. } \\
\text { Alkaline phosphatase (ALP) activity in the osteoblast } \\
\text { line was increased after } 830 \mathrm{~nm} \text { laser irradiation } \\
\text { at } 10 \mathrm{~J} / \mathrm{cm}^{2}\end{array}$ \\
\hline [18] & Diode & MC3T3-E1 & $\begin{array}{l}2010 \\
\text { Fujimoto et al. }\end{array}$ & $\begin{array}{c}830 \mathrm{~nm} \\
0.97,1.91 \text {, or } 3.82 \mathrm{~J} / \mathrm{cm}^{2} \\
2 \mathrm{~Hz} \\
5,10, \text { or } 20 \mathrm{~min}\end{array}$ & $\begin{array}{c}\text { Expression of bone morphogenetic protein (BMP)-2, 4, } \\
\text { and } 7 \text { were significantly increased at } 6,9,12 \mathrm{~h} \text {. } \\
\text { Runt-related protein transcription factor } 2 \text { (Runx } 2), \\
\text { Osx, distal-less homeobox } 5 \text { (Dlx5), and Msh } \\
\text { homeobox } 2 \text { (Ms } x 2 \text { ) expression was significantly } \\
\text { increased at } 12,24,48 \mathrm{~h} \text {. }\end{array}$ \\
\hline [19] & Diode & MC3T3-E1 & $\begin{array}{l}2011 \\
\text { Kanenari, et al. }\end{array}$ & $\begin{array}{l}830 \mathrm{~nm} \\
7.64 \mathrm{~J} / \mathrm{cm}^{2} \\
20 \mathrm{~min}\end{array}$ & $\begin{array}{l}\text { Laser irradiation enhances Map1a gene expression and } \\
\text { modulates microtubule assembly and the functional } \\
\text { structure of microtubules, in turn, stimulates } \\
\text { osteoblastic proliferation and differentiation. }\end{array}$ \\
\hline [20] & Diode & MC3T3-E1 & $\begin{array}{c}2014 \\
\text { Migliario, et al. }\end{array}$ & $\begin{array}{c}980 \mathrm{~nm} \\
1.57,7.87,15.74, \text { or } 78.75 \mathrm{~J} / \mathrm{cm}^{2} \\
\mathrm{CW} \\
1,5,10,25 \text {, or } 50 \mathrm{~s}\end{array}$ & $\begin{array}{l}\text { Laser irradiation enhances cell proliferation via } \\
\text { ROS production. }\end{array}$ \\
\hline [21] & Diode & MC3T3-E1 & $\begin{array}{c}2014 \\
\text { Pagin, et al. }\end{array}$ & $\begin{array}{c}660 \text { and } 780 \mathrm{~nm} \\
3,5 \mathrm{~J} / \mathrm{cm}^{2} \\
\text { Punctual irradiation mode } \\
2 \text { and } 5 \mathrm{~s}\end{array}$ & $\begin{array}{l}\text { Laser irradiation significantly promoted cell growth } \\
\text { at } 24 \mathrm{~h} \text {. }\end{array}$ \\
\hline
\end{tabular}


Table 1. Cont.

\begin{tabular}{|c|c|c|c|c|c|}
\hline Reference No. & Laser & Cell & Year Author & Irradiation Protocol & Major Findings \\
\hline [22] & Diode & MC3T3-E1 & $\begin{array}{c}2017 \\
\text { Oliveira, et al. }\end{array}$ & $\begin{array}{c}660 \text { or } 780 \mathrm{~nm} \\
1.9, \text { or } 3.8 \mathrm{~J} / \mathrm{cm}^{2} \\
\mathrm{CW} \\
4 \text { or } 8 \mathrm{~s}\end{array}$ & $\begin{array}{l}\text { Laser irradiation at both wavelengths significantly } \\
\text { increased cell viability on } 24 \text { and } 48 \mathrm{~h} \text {. } \\
\text { Infrared Ga-Al-As laser at } 780 \mathrm{~nm} \text { significantly } \\
\text { increased ALP activity on } 24 \text { and } 72 \mathrm{~h} \text {. } \\
\text { Red laser at } 660 \mathrm{~nm} \text { significantly increased matrix } \\
\text { metalloproteinase (MMP)-2 activities on } 48 \text { and } 72 \mathrm{~h} \text {. }\end{array}$ \\
\hline [23] & Diode & MC3T3-E1 & $\begin{array}{l}2017 \\
\text { Son, et al. }\end{array}$ & $\begin{array}{c}808 \mathrm{~nm} \pm 5 \mathrm{~nm} \\
1.2 \mathrm{~J} / \mathrm{cm}^{2} \\
\mathrm{CW} 15 \mathrm{~s} \\
3 \text { times at } 0,24 \text {, and } 48 \mathrm{~h}\end{array}$ & $\begin{array}{l}\text { Laser irradiation with melatonin treatment increased } \\
\text { significantly Osterix }(S p 7) \text { expression at } 48 \text { and } 72 \mathrm{~h} \\
\text { and ALP activity and calcification on day } 7 \text { and } 14 .\end{array}$ \\
\hline [24] & Diode & MC3T3-E1 & $\begin{array}{l}2017 \\
\text { Li, et al. }\end{array}$ & $\begin{array}{c}808 \mathrm{~nm} \\
1.25,3.75, \text { or } 6.25 \mathrm{~J} / \mathrm{cm}^{2} \\
\text { CW } \\
30,90 \text {, or } 150 \mathrm{~s}\end{array}$ & $\begin{array}{c}\text { Irradiation at } 3.75 \mathrm{~J} / \mathrm{cm}^{2} \text { increased the cell amount at } \mathrm{S} \\
\text { phase and promoted cell proliferation through } \\
\text { hedgehog signaling pathway at } 24 \mathrm{~h} \text {. } \\
\text { The expressions of } \mathrm{Ihh}, \text { Ptch, Smo, and Gli were } \\
\text { significantly increased by } 3.75 \mathrm{~J} / \mathrm{cm}^{2} \text { irradiation. }\end{array}$ \\
\hline [25] & Diode & MC3T3-E1 & $\begin{array}{c}2018 \\
\text { Kunimatsu, et al. }\end{array}$ & $\begin{array}{c}910 \mathrm{~nm} \\
0,1.42,2.85,5.7, \text { or } 17.1 \mathrm{~J} / \mathrm{cm}^{2} \\
\text { Pulsed } \\
30 \mathrm{kHz}\end{array}$ & $\begin{array}{l}\text { Cell proliferation was significantly increased by laser } \\
\text { irradiation at a dose of } 2.85,5.7, \text { or } 17.1 \mathrm{~J} / \mathrm{cm}^{2} \text {. } \\
\text { Laser irradiation at a dose of } 2.85 \mathrm{~J} / \mathrm{cm}^{2} \text { induced } \\
\text { MC3T3-E1 cells to migrate more rapidly than } \\
\text { nonirradiated control cells. } \\
\text { Irradiation with the high-frequency } 910 \text { nm diode } \\
\text { laser at a dose of } 2.85 \mathrm{~J} / \mathrm{cm}^{2} \text { induces phosphorylation } \\
\text { of Mitogen-activated protein kinase } \\
\text { (MAPK)/extracellular signal-regulated kinase } \\
\text { (ERK) } 1 / 2 \text { at } 15 \text { and } 30 \text { min later irradiation } \\
\text { Laser irradiation significantly accelerated cell }\end{array}$ \\
\hline [26] & Diode & МС3Т3-E1 & $\begin{array}{l}2018 \\
\text { Mikami, et al. }\end{array}$ & $\begin{array}{c}405 \mathrm{~nm} \\
1.9,5.6,9.4,13.1 \text {, or } 16.9 \mathrm{~J} / \mathrm{cm}^{2} \\
\text { Pulsed } \\
80 \mathrm{MHz} \\
1 \mathrm{~min}\end{array}$ & $\begin{array}{c}\text { proliferation activity on day } 3 \text { and ALP activity on day } \\
7 \text { via transient receptor potential vanilloid 1(TRPV1). } \\
\text { Expression of Alpl, Sp7, and Runx2 mRNAs was } \\
\text { significantly increased. } \\
\text { Calcification was significantly increased } 3 \text { weeks later } \\
\text { after final irradiation on day } 2,4,6,9 \text {, and } 11 .\end{array}$ \\
\hline [27] & Diode & Saos-2 & $\begin{array}{c}2000 \\
\text { Coombe, et al. }\end{array}$ & $\begin{array}{c}830 \mathrm{~nm} \\
1.7-25.1 \mathrm{~J} / \mathrm{cm}^{2} \\
\mathrm{CW} \\
\text { Single or multiple for } 10 \text { days }\end{array}$ & $\begin{array}{l}\text { Cellular proliferation or activation of osteoblastic cells } \\
\text { was not significantly affected by laser irradiation. }\end{array}$ \\
\hline
\end{tabular}


Table 1. Cont.

\begin{tabular}{|c|c|c|c|c|c|}
\hline Reference No. & Laser & Cell & Year Author & Irradiation Protocol & Major Findings \\
\hline [28] & Diode & Saos-2 & $\begin{array}{c}2013 \\
\text { Bayram, et al. }\end{array}$ & $\begin{array}{l}808 \mathrm{~nm} \\
1.316, \text { or } 2.63 \mathrm{~J} / \mathrm{cm}^{2} \\
\mathrm{CW} \\
10 \mathrm{~s}\end{array}$ & $\begin{array}{l}\text { Laser irradiation lessened the detrimental effects of } \\
\text { zoledronate, improved cell function and/or } \\
\text { proliferation, and ALP activity. }\end{array}$ \\
\hline [29] & Diode & Saos-2 & $\begin{array}{c}2013 \\
\text { Bloise, et al. }\end{array}$ & $\begin{array}{c}659 \mathrm{~nm} \\
1 \text { and } 3 \mathrm{~J} / \mathrm{cm}^{2} \\
200 \text { or } 600 \mathrm{~s} \\
\text { Single or multiple for } 3 \text { days }\end{array}$ & $\begin{array}{c}\text { Cell proliferation is significantly increased on day } 2 \text { by } \\
\text { single dose of } 1 \mathrm{~J} / \mathrm{cm}^{2} \text { and on day } 2,3 \text {, and } 7 \text { with } \\
\text { multiple doses of } 1 \text { and } 3 \mathrm{~J} / \mathrm{cm}^{2} \text {. ALP activity on day } \\
14 \text { and calcification on day } 14 \text { were increased } \\
\text { significantly. }\end{array}$ \\
\hline [30] & Diode & Saos-2 & $\begin{array}{c}2014 \\
\text { Incerti Parenti, et al. }\end{array}$ & $\begin{array}{c}915 \mathrm{~nm} \\
1,5,10,20, \text { or } 50 \mathrm{~J} / \mathrm{cm}^{2} \\
\text { Pulsed } \\
100 \mathrm{~Hz} \\
10,48,96,193 \text {, or } 482 \mathrm{~s}\end{array}$ & $\begin{array}{l}\text { Cell viability was significantly increased on day } 3 \text { by } \\
\text { irradiation at } 10 \mathrm{~J} / \mathrm{cm}^{2}, \text { but significantly decreased by } \\
\text { irradiation at } 20 \text { and } 50 \mathrm{~J} / \mathrm{cm}^{2} \text {. } \\
\text { A rapid and transitory trend toward increased } \\
\text { receptor activator of NF- } \mathrm{kB} \text { ligand } \\
\text { (RANKL)/osteoprotegerin ( OPG) ratio and a } \\
\text { tendency toward a delayed increase in VEGF release } \\
\text { for doses of } 1 \text { to } 10 \mathrm{~J} / \mathrm{cm}^{2} \text { was found. } \\
\text { Wound healing was significantly promoted at }\end{array}$ \\
\hline [31] & Diode & Saos-2 & $\begin{array}{c}2015 \\
\text { Tschon, et al. }\end{array}$ & $\begin{array}{c}915 \mathrm{~nm} \\
5,10, \text { or } 15 \mathrm{~J} / \mathrm{cm}^{2} \\
\text { Pulsed } \\
100 \mathrm{~Hz} \\
0,48,96 \text {, or } 144 \mathrm{~s}\end{array}$ & $\begin{array}{l}72 \text { and } 96 \mathrm{~h} \text {. } \\
\text { COL1A1 expression was significantly increased at 24, } \\
48 \text {, and } 72 \mathrm{~h} \text {. } \\
\text { transforming growth factor (TGF) B1 expression } \\
\text { significantly decreased TGFB1 expression at } \\
48 \text { and } 72 \mathrm{~h} \text {. }\end{array}$ \\
\hline [32] & Diode & HOB and Saos-2 & $\begin{array}{c}2016 \\
\text { Heymann, et al. }\end{array}$ & $\begin{array}{l}670 \mathrm{~nm} \\
100 \mathrm{~mW} / \mathrm{cm}^{2} \\
\mathrm{CW} \\
120 \mathrm{~s}\end{array}$ & Laser irradiation alone increased cell bioavailability. \\
\hline [33] & Diode & Saos-2 & $\begin{array}{c}2018 \\
\text { Tani, et al. }\end{array}$ & $\begin{array}{c}635 \text { or } 808 \mathrm{~nm} \\
0.378 \mathrm{~J} / \mathrm{cm}^{2} \\
\mathrm{CW} \\
30 \mathrm{~s}\end{array}$ & $\begin{array}{c}\text { Laser irradiation caused no differences in viability } \\
\text { at } 24 \mathrm{~h} \text {. } \\
\text { Laser irradiation increased expression of } R U N X 2 \text {, } \\
A L P L \text {, and osteopontin (SPP1) on } 7 \text { days and } \\
\text { calcification on } 18 \text { days by activation of Akt signaling. }\end{array}$ \\
\hline [34] & Diode & Saos-2 & $\begin{array}{c}2008 \\
\text { Stein, et al. }\end{array}$ & $\begin{array}{l}670 \mathrm{~nm} \\
1 \text { or } 2 \mathrm{~J} / \mathrm{cm}^{2} \\
\text { CW } \\
30 \mathrm{~s} \text { or } 1 \mathrm{~min}\end{array}$ & $\begin{array}{l}\text { Cell viability, alkaline phosphatase activity, and the } \\
\text { expression of osteopontin and collagen type I mRNA } \\
\text { were slightly enhanced in cells irradiated with } 1 \mathrm{~J} / \mathrm{cm}^{2}\end{array}$ \\
\hline
\end{tabular}


Table 1. Cont.

\begin{tabular}{|c|c|c|c|c|c|}
\hline Reference No. & Laser & Cell & Year Author & Irradiation Protocol & Major Findings \\
\hline [35] & Diode & MG-63 & $\begin{array}{l}2009 \\
\text { Saracino, et al. }\end{array}$ & $\begin{array}{l}910 \mathrm{~nm} \\
6.7 \mathrm{~J} / \mathrm{cm}^{2} \\
30 \mathrm{kHz} \\
5 \mathrm{~min}\end{array}$ & $\begin{array}{l}\text { Laser irradiation decreased cell growth, induced } \\
\text { expression of } T G F B 2, B M P-4, \text { and } B M P-7, \text { type I } \\
\text { collagen, } A L P L \text {, and osteocalcin, and increased the } \\
\text { size and the number of calcium deposits. } \\
\text { Laser irradiation promoted cell adhesion at } 12 \mathrm{~h} \text { and }\end{array}$ \\
\hline [36] & Diode & MG-63 & $\begin{array}{c}2012 \\
\text { Huang, et al. }\end{array}$ & $\begin{array}{c}920 \mathrm{~nm} \\
5, \text { or } 10 \mathrm{~J} / \mathrm{cm}^{2} \\
50-60 \mathrm{~Hz} \\
2.5 \text { or } 5 \mathrm{~s}\end{array}$ & $\begin{array}{c}\text { cell viability at } 1 \text { and } 12 \mathrm{~h} \text {. } \\
\text { Laser irradiation reduced the expression of the } \\
\text { lipopolysaccharide (LPS)-induced inflammatory } \\
\text { markers iNOS (INOS), tumour necrosis factor } \alpha \\
\text { (TNFA), and IL1B and increased the expression of } \\
\text { phospho-ERK. }\end{array}$ \\
\hline [37] & Diode & MG-63 & $\begin{array}{c}2014 \\
\text { Huertas, et al. }\end{array}$ & $\begin{array}{c}940 \mathrm{~nm} \\
0.5,1,1.5, \text { or } 2 \mathrm{~W} / \mathrm{cm}^{2} \\
70 \mathrm{~mW} \\
1,2,3,4, \text { or } 5 \mathrm{~J}\end{array}$ & At $24 \mathrm{~h}$ culture, cell proliferation was increased. \\
\hline [38] & Diode & MG-63 & $\begin{array}{l}2013 \\
\text { Incerti Parenti, et al. }\end{array}$ & $\begin{array}{c}915 \mathrm{~nm} \\
2 \mathrm{~J} / \mathrm{cm}^{2} \\
\mathrm{CW} \\
17,31, \text { or } 157 \mathrm{~s}\end{array}$ & $\begin{array}{l}\text { Laser irradiation did not interfere in cell viability } \\
\text { and proliferation. }\end{array}$ \\
\hline [39] & Diode & MG-63 & $\begin{array}{c}2014 \\
\text { Medina-Huertas, et al. }\end{array}$ & $\begin{array}{c}940 \mathrm{~nm} \\
1,1.5 \mathrm{~W} / \mathrm{cm}^{2} \\
3,4 \mathrm{~J} \\
10.6,12.96,14.7, \text { or } 19.31 \mathrm{~s}\end{array}$ & $\begin{array}{l}\text { ALP activity was increased significantly at } 24 \mathrm{~h} \text { by } \\
\text { irradiation at } 1 \mathrm{~W} / \mathrm{cm}^{2} \text { and } 3 \mathrm{~J} . \\
\text { CD54, CD86, and HLA-DR were decreased at } 24 \mathrm{~h} \text {. }\end{array}$ \\
\hline [40] & Diode & MG-63 & $\begin{array}{l}2015 \\
\text { Manzano-Moreno, et al. }\end{array}$ & $\begin{array}{c}940 \mathrm{~nm} \\
1, \text { or } 1.5 \mathrm{~W} \\
3 \text { or } 4 \mathrm{~J}\end{array}$ & $\begin{array}{c}\text { Laser irradiation significantly increased gene } \\
\text { expression of } R U N X 2, S P 7, C O L 1 A, A L P L, B M P 2, \\
\text { and TGFB1 at } 24 \mathrm{~h} .\end{array}$ \\
\hline [41] & Diode & hFOB 1.19 & $\begin{array}{c}2013 \\
\text { Pyo, et al. }\end{array}$ & $\begin{array}{c}808 \pm 3 \mathrm{~nm} \\
1.2,2.4, \text { or } 3.6 \mathrm{~J} / \mathrm{cm}^{2} \\
\mathrm{CW} \\
15 \mathrm{~s} \text { at } 0,24,48 \mathrm{~h}\end{array}$ & $\begin{array}{c}\text { Laser irradiation on hypoxic-cultured osteoblast } \\
\text { stimulates osteoblast differentiation and proliferation } \\
\text { at } 24 \text { and } 72 \mathrm{~h} \text {. } \\
\text { Laser irradiation significantly increased expression of } \\
B M P-2 \text {, osteocalcin, Type } 1 \text { collagen, and TGFB1. } \\
\text { Type } 1 \text { collagen expression were significantly } \\
\text { decreased at } 48 \text { and } 72 \mathrm{~h} \text {. }\end{array}$ \\
\hline [42] & Diode & hFOB 1.19 & $\begin{array}{l}2013 \\
\text { Jawad, et al. }\end{array}$ & $\begin{array}{c}940 \mathrm{~nm} \\
22.92,45.85,68.78,91.79, \text { or } 137.57 \mathrm{~J} / \mathrm{cm}^{2} \\
\mathrm{CW} \\
3 \text { or } 6 \mathrm{~min} / \text { day for } 7 \text { days }\end{array}$ & $\begin{array}{c}\text { Laser irradiation significantly increased proliferation } \\
\text { and ALP activity on day } 3 \text { and } 7 . \\
\text { Osteocalcin activity was significantly increased } \\
\text { on day } 7 .\end{array}$ \\
\hline
\end{tabular}


Table 1. Cont

\begin{tabular}{|c|c|c|c|c|c|}
\hline Reference No. & Laser & Cell & Year Author & Irradiation Protocol & Major Findings \\
\hline [43] & Diode & $\begin{array}{l}\text { HHOB-c; Human } \\
\text { osteogenic cells }\end{array}$ & $\begin{array}{c}2015 \\
\text { Walter, et al. }\end{array}$ & $\begin{array}{l}670 \mathrm{~nm} \\
280 \mathrm{~mW} \\
60 \mathrm{~s} \\
\mathrm{CW}\end{array}$ & $\begin{array}{l}\text { Laser irradiation increased the viability of cells, but } \\
\text { was significant only in the experimental approach } \\
\text { with pamidronate. }\end{array}$ \\
\hline [44] & Diode & hFOB 1.19 & $\begin{array}{c}2016 \\
\text { Shin, et al. }\end{array}$ & $\begin{array}{c}808 \pm 3 \mathrm{~nm} \\
1.2 \mathrm{~J} / \mathrm{cm}^{2} \\
\mathrm{CW} \\
15 \mathrm{~s} \\
3 \text { times at } 1,24,48 \mathrm{~h}\end{array}$ & $\begin{array}{c}\text { Laser irradiation significantly increased cell viability } \\
\text { at } 72 \mathrm{~h} \text {. } \\
\text { Expression of } R A N K L \text { and M-CSF (CSF1) were } \\
\text { significantly increased at } 72 \mathrm{~h} \text {. }\end{array}$ \\
\hline [45] & Diode & $\begin{array}{l}\text { Human osteoblasts cell } \\
\text { line (ATCC }{ }^{\circledR} \text { CRL-11372) }\end{array}$ & $\begin{array}{l}2017 \\
\text { Bolukbasi Ateş, et al. }\end{array}$ & $\begin{array}{c}635 \text { or } 809 \mathrm{~nm} \\
0.5,1, \text { or } 2 \mathrm{~J} / \mathrm{cm}^{2} \\
\mathrm{CW} \\
10,20, \text { or } 40 \mathrm{~s}\end{array}$ & $\begin{array}{c}\text { Viability was significantly increased at } 48 \text { and } 72 \mathrm{~h} \text {. } \\
\text { Expression of COL1A was significantly increased by } 1 \\
\text { and } 2 \mathrm{~J} / \mathrm{cm}^{2} \text { at day } 14 \text {. } \\
\text { Expression of } B G L A P \text { was significantly decreased by } \\
0.5,1 \text { and } 2 \mathrm{~J} / \mathrm{cm}^{2} \text { at day } 14 \text {. }\end{array}$ \\
\hline [46] & Diode & $\begin{array}{l}\text { Human osteoblasts cell } \\
\text { line (ATCC }{ }^{\circledR} \text { CRL-11372) }\end{array}$ & $\begin{array}{c}2018 \\
\text { Ateş, et al. }\end{array}$ & $\begin{array}{c}809 \mathrm{~nm} \\
0.5,1, \text { or } 2 \mathrm{~J} / \mathrm{cm}^{2} \\
\mathrm{CW} \\
10,20, \text { or } 40 \mathrm{~s}\end{array}$ & $\begin{array}{l}\text { Laser irradiation at } 2 \mathrm{~J} / \mathrm{cm}^{2} \text { significantly increased cell } \\
\text { viability at } 24 \mathrm{~h} \text {. } \\
\text { ALP activity was significantly enhanced on day } 7 . \\
\text { Mineralization was significantly increased on day } 14 \\
\text { The expression of } A L P L, C O L 1 A \text {, and } B G L A P \text { was } \\
\text { significantly increased on day } 7 \text { and/or } 14 \text {. }\end{array}$ \\
\hline [47] & Diode & hFOB 1.19 & $\begin{array}{c}2018 \\
\text { Jeong, et al. }\end{array}$ & $\begin{array}{l}808 \pm 3 \mathrm{~nm} \\
1.2 \mathrm{~J} / \mathrm{cm}^{2} \\
\mathrm{CW} \\
15 \mathrm{~s}\end{array}$ & $\begin{array}{l}\text { Combined application of rhBMP-2 and laser } \\
\text { irradiation was more effective than application of } \\
\text { either modality alone. } \\
\text { Expression of RANKL, OPG, and M-CSF in hFOB cells } \\
\text { were increased following application of rhBMP-2 and } \\
\text { laser irradiation. } \\
\text { The expression of TGFB1, BMP2, collagen type I, } \\
\text { and osteopontin were increased following combined } \\
\text { application of rhBMP-2 and laser irradiation. }\end{array}$ \\
\hline [48] & Diode & $\begin{array}{l}\text { Osteo-1; Rat calvarial } \\
\text { osteoblast-like cells }\end{array}$ & $\begin{array}{c}2006 \\
\text { Fujihara, et al. }\end{array}$ & $\begin{array}{l}780 \mathrm{~nm} \\
3 \mathrm{~J} / \mathrm{cm}^{2} \\
\mathrm{CW} \\
12 \mathrm{~s}\end{array}$ & $\begin{array}{l}\text { Irradiation significantly increased cell proliferation } \\
\text { with and without dexamethasone. }\end{array}$ \\
\hline
\end{tabular}


Table 1. Cont.

\begin{tabular}{|c|c|c|c|c|c|}
\hline Reference No. & Laser & Cell & Year Author & Irradiation Protocol & Major Findings \\
\hline [49] & Diode & $\begin{array}{l}\text { Rat primary calvarial } \\
\text { osteoblastic cells }\end{array}$ & $\begin{array}{c}2006 \\
\text { Fukuhara, et al. }\end{array}$ & $\begin{array}{c}905 \mathrm{~nm} \\
1.25,3.75 \text {, or } 6.25 \mathrm{~J} / \mathrm{cm}^{2} \\
150,450 \text {, or } 750 \mathrm{~s} \\
\text { Every day for } 1-3 \text { weeks }\end{array}$ & $\begin{array}{c}\text { Irradiation energy of } 3.75 \mathrm{~J} / \mathrm{cm}^{2} \text { induced an increased } \\
\text { number of cells at day } 3 \text { and the greatest bone } \\
\text { formation at day } 21 . \\
\text { Low-energy laser irradiation increased Runx } 2 \\
\text { expression and ALP-positive colonies. } \\
\text { FACS data demonstrated a higher proportion of cells } \\
\text { in the G2/M phase of the cell cycle } 12 \mathrm{~h} \text { after } \\
\text { irradiation compared with the control. }\end{array}$ \\
\hline [50] & Diode & $\begin{array}{l}\text { Rat primary calvarial } \\
\text { osteoblastic cells }\end{array}$ & $\begin{array}{c}2007 \\
\text { Shimizu, et al. }\end{array}$ & $\begin{array}{l}830 \mathrm{~nm} \\
3.82 \mathrm{~J} / \mathrm{cm}^{2} \\
\mathrm{CW} \\
10 \mathrm{~min}\end{array}$ & $\begin{array}{l}\text { Irradiation increased bone nodule formation at day } 24 \\
\text { post-irradiation which is partly mediated by } \\
\text { insulin-like growth factor-1 (IGF-I) expression. }\end{array}$ \\
\hline [51] & Diode & $\begin{array}{l}\text { Rat primary calvarial } \\
\text { osteoblastic cells }\end{array}$ & $\begin{array}{c}2009 \\
\text { Xu, et al. }\end{array}$ & $\begin{array}{l}650 \mathrm{~nm} \\
1.14 \text { or } 2.28 \mathrm{~J} / \mathrm{cm}^{2} \\
6000 \mathrm{~Hz} \\
5 \text { or } 10 \mathrm{~min}\end{array}$ & $\begin{array}{l}\text { Laser irradiation may directly promote osteoblast } \\
\text { proliferation on day } 3 \text { and differentiation. } \\
\text { Irradiation significantly downregulated RANKL and } \\
\text { upregulated OPG, downregulating the RANKL:OPG } \\
\text { mRNA ratio in osteoblasts. }\end{array}$ \\
\hline [52] & Diode & $\begin{array}{l}\text { Rat primary calvarial } \\
\text { osteoblastic cells }\end{array}$ & $\begin{array}{c}1998 \\
\text { Ozawa, et al. }\end{array}$ & $\begin{array}{l}830 \mathrm{~nm} \\
3.82 \mathrm{~J} / \mathrm{cm}^{2} \\
\mathrm{CW} \\
10 \mathrm{~min}\end{array}$ & $\begin{array}{l}\text { Laser irradiation significantly stimulated cellular } \\
\text { proliferation, ALP activity, and osteocalcin gene } \\
\text { expression thereafter. } \\
\text { Laser irradiation at earlier stages of culture } \\
\text { significantly stimulated bone nodules formation in the } \\
\text { culture dish on day } 21 .\end{array}$ \\
\hline [53] & Diode & $\begin{array}{l}\text { Rat primary calvarial } \\
\text { osteoblastic cells }\end{array}$ & $\begin{array}{c}2001 \\
\text { Ueda and Shimizu }\end{array}$ & $\begin{array}{c}830 \mathrm{~nm} \\
0.48-3.84 \mathrm{~J} / \mathrm{cm}^{2} \\
\mathrm{CW} \text { or pulsed }(1,2,8 \mathrm{~Hz}) \\
1.25-10 \text { for } 2.5-20 \mathrm{~min}\end{array}$ & $\begin{array}{c}\text { Both CW and pulsed irradiation significantly } \\
\text { enhanced cell proliferation, bone nodule formation, } \\
\text { ALP activity, and Alpl gene expression as compared } \\
\text { with the nonirradiated group. }\end{array}$ \\
\hline [54] & Diode & $\begin{array}{l}\text { Rat primary calvarial } \\
\text { osteoblastic cells }\end{array}$ & $\begin{array}{c}2003 \\
\text { Ueda and Shimizu }\end{array}$ & $\begin{array}{c}830 \mathrm{~nm} \\
0.48-3.84 \mathrm{~J} / \mathrm{cm}^{2} \\
\mathrm{CW} \text { or pulsed }(1,2, \text { and } 8 \mathrm{~Hz}) \\
1.25-10 \text { for } 2.5-20 \mathrm{~min}\end{array}$ & $\begin{array}{l}\text { Laser irradiation on day } 1 \text { at all conditions } \\
\text { significantly stimulated cellular proliferation on day } 6 \text {, } \\
9 \text {, and } 12 \text { as compared with the controls. }\end{array}$ \\
\hline [55] & Diode & $\begin{array}{c}\text { Primary human } \\
\text { osteoblast-like cells from } \\
\text { mandibular }\end{array}$ & $\begin{array}{c}2005 \\
\text { Khadra, et al. }\end{array}$ & $\begin{array}{c}830 \mathrm{~nm} \\
1.5 \text { and } 3 \mathrm{~J} / \mathrm{cm}^{2} \\
\mathrm{CW} \\
\text { For } 3 \text { consecutive days }\end{array}$ & $\begin{array}{l}\text { Greater cell proliferation in the irradiated groups was } \\
\text { observed first after } 96 \mathrm{~h} \text {. } \\
\text { Osteocalcin synthesis and TGF-b1 production were } \\
\text { significantly greater on the samples exposed to } 3 \mathrm{~J} / \mathrm{cm}^{2}\end{array}$ \\
\hline [56] & Diode & $\begin{array}{l}\text { Rat primary calvarial } \\
\text { osteoblastic cells }\end{array}$ & $\begin{array}{c}2020 \\
\text { Cardoso, et al. }\end{array}$ & $\begin{array}{c}660 \text { or } 808 \mathrm{~nm} \\
5,8.3 \mathrm{~J} / \mathrm{cm}^{2} \\
\mathrm{CW} \\
3 \text { and } 5 \mathrm{~s}\end{array}$ & $\begin{array}{l}\text { Laser irradiation at both wavelengths promoted cell } \\
\text { proliferation and wound healing. } \\
\text { ALP activity and mineralization were } \\
\text { significantly increased. }\end{array}$ \\
\hline
\end{tabular}


Table 1. Cont.

\begin{tabular}{|c|c|c|c|c|c|}
\hline Reference No. & Laser & Cell & Year Author & Irradiation Protocol & Major Findings \\
\hline [57] & Diode & $\begin{array}{l}\text { Primary human } \\
\text { osteoblast-like cells from } \\
\text { alveolar }\end{array}$ & $\begin{array}{c}2010 \\
\text { Petri, et al. }\end{array}$ & $\begin{array}{c}780 \mathrm{~nm} \\
3 \mathrm{~J} / \mathrm{cm}^{2} \\
\mathrm{CW} \\
9 \mathrm{~min} \text { on day } 3 \text { and } 7\end{array}$ & $\begin{array}{l}\text { Laser irradiation did not influence culture growth, } \\
\text { ALP activity, and mineralized matrix formation. } \\
\text { Gene expression of } A L P L, B G L A P, I B S P \text {, and } B M P 7 \\
\text { was higher in laser-treated cultures, while } R U N X 2, \\
\text { SPP1, and OPG (TNFRSF11B) were lower on day } 14 .\end{array}$ \\
\hline [58] & Diode & $\begin{array}{l}\text { Rat primary calvarial } \\
\text { osteoblast-like cells }\end{array}$ & $\begin{array}{c}2013 \\
\text { Emes, et al. }\end{array}$ & $\begin{array}{l}808 \mathrm{~nm} \\
1.5 \mathrm{~J} / \mathrm{cm}^{2} \\
\mathrm{CW} \\
90 \mathrm{~s}\end{array}$ & $\begin{array}{l}\text { Laser irradiation did not affect cell proliferation and } \\
\text { ALP activity. }\end{array}$ \\
\hline [59] & Diode & $\begin{array}{l}\text { Primary human } \\
\text { osteoblast-like cells from } \\
\text { femur }\end{array}$ & $\begin{array}{l}2019 \\
\text { Morsoleto, et al. }\end{array}$ & $\begin{array}{l}808 \mathrm{~nm} \\
2 \mathrm{~J} / \mathrm{cm}^{2} \\
5 \mathrm{~s} \\
\text { Every day for } 8 \text { days }\end{array}$ & $\begin{array}{l}\text { Laser irradiations on } 1-8 \text { days enhanced cell viability } \\
\text { and matrix mineralization on day } 18 .\end{array}$ \\
\hline [60] & Diode & $\begin{array}{l}\text { A mouse OFCOL II cell } \\
\text { line }\end{array}$ & $\begin{array}{l}2008 \\
\text { Pires Oliveira, et al. }\end{array}$ & $\begin{array}{c}830 \mathrm{~nm} \\
3 \mathrm{~J} / \mathrm{cm}^{2} \\
\mathrm{CW} \\
36 \mathrm{~s}\end{array}$ & $\begin{array}{c}\text { Cellular viability was significantly increased at } 24,48 \\
\text { and } 72 \mathrm{~h} \text { after irradiation. } \\
\text { Intense grouping of mitochondria in the perinuclear } \\
\text { region was observed at } 24 \text { and } 48 \mathrm{~h} \text {. Changes from a } \\
\text { filamentous to a granular appearance in mitochondrial } \\
\text { morphology and mitochondria distributed } \\
\text { throughout the cytoplasm were observed } 72 \mathrm{~h} \text {. }\end{array}$ \\
\hline [61] & Diode & $\begin{array}{l}\text { Osteoblasts from rat bone } \\
\text { marrow stem cells }\end{array}$ & $\begin{array}{l}2000 \\
\text { Dortbudak, et al. }\end{array}$ & $\begin{array}{c}690 \mathrm{~nm} \\
1.6 \mathrm{~J} / \mathrm{cm}^{2} \\
\mathrm{CW} \\
60 \mathrm{~s} \\
3 \text { times on day } 3,5 \text {, and } 7\end{array}$ & $\begin{array}{c}\text { Irradiations } 3 \text { times on day 3, 5, and } 7 \text { significantly } \\
\text { enhanced more fluorescent bone deposits than the } \\
\text { nonirradiated cultures. }\end{array}$ \\
\hline [62] & Diode & $\begin{array}{l}\text { Primary human } \\
\text { osteoblast-like cells from } \\
\text { alveolar }\end{array}$ & $\begin{array}{l}2011 \\
\text { Grassi, et al. }\end{array}$ & $\begin{array}{l}920 \mathrm{~nm} \\
3 \mathrm{~J} / \mathrm{cm}^{2} \\
\mathrm{CW} \\
60 \mathrm{~s}\end{array}$ & $\begin{array}{l}\text { Laser irradiation significantly enhanced Alp activity } \\
\text { on day } 7 \text { and } 14 \text { and mineralization after } 5 \text { weeks. } \\
\text { Laser irradiation decreased Runx } 2 \text { and } S p 7 \text { mRNA at } \\
\qquad 3,6 \text {, and } 12 \mathrm{~h} \text {. }\end{array}$ \\
\hline [63] & Diode & $\begin{array}{l}\text { Primary human } \\
\text { osteoblast-like cells from } \\
\text { mandibular }\end{array}$ & $\begin{array}{c}2018 \\
\text { Mergoni, et al. }\end{array}$ & $\begin{array}{c}915 \mathrm{~nm} \\
5,15, \text { and } 45 \mathrm{~J} / \mathrm{cm}^{2} \\
\mathrm{CW} \\
4,12,36,41.7,125 \text {, and } 375 \mathrm{~s} \\
\text { Every day for } 3 \text { or } 6 \text { days }\end{array}$ & $\begin{array}{l}\text { Irradiation for } 6 \text { days significantly increased bone } \\
\text { deposits } 3 \text { weeks after irradiation. }\end{array}$ \\
\hline
\end{tabular}


Table 1. Cont.

\begin{tabular}{|c|c|c|c|c|c|}
\hline Reference No. & Laser & Cell & Year Author & Irradiation Protocol & Major Findings \\
\hline [64] & Diode & $\begin{array}{l}\text { Mouse primary calvarial } \\
\text { osteoblasts }\end{array}$ & $\begin{array}{l}2010 \\
\text { Hirata, et al. }\end{array}$ & $\begin{array}{c}805 \mathrm{~nm} \\
2-12 \mathrm{~J} / \mathrm{cm}^{2} \\
\mathrm{CW} \\
2 \mathrm{~min}\end{array}$ & $\begin{array}{c}\text { Irradiation stimulated BMP2-induced } \\
\text { phosphorylation of Smad1/5/8 and Bmp2 expression, } \\
\text { but had no effect on the expression of inhibitory } \\
\text { Smads6, Smad7, Bmp4, or insulin-like growth factor } 1 . \\
\text { Laser irradiation enhanced Smad-induced Id1 } \\
\text { reporter activity and BMP-induced transcription } \\
\text { factors such as Id1, Osterix, and Runx2. } \\
\text { Laser irradiation also stimulated BMP-induced } \\
\text { expressions of type I collagen, osteonectin, } \\
\text { and osteocalcin mRNA. }\end{array}$ \\
\hline [75] & Nd:YAG & Saos-2 & $\begin{array}{c}2006 \\
\text { Arisu, et al. }\end{array}$ & $\begin{array}{c}1064 \mathrm{~nm} \\
20,60,80, \text { and } 120 \mathrm{~mJ} \\
0.2,0.6,0.8,0.9,1.2,1.6,1.8,2.4 \text {, and } 3.6 \mathrm{~W} \\
\text { Pulsed } \\
10,15,20, \text { and } 30 \mathrm{~Hz} \\
10 \mathrm{~s}\end{array}$ & $\begin{array}{l}\text { Irradiation had a stimulatory effect on the cell viability } \\
\text { and proliferation at } 7,14 \text {, and } 21 \text { days. }\end{array}$ \\
\hline [76] & Nd:YAG & Saos-2 & $\begin{array}{c}2010 \\
\text { Chellini, et al. }\end{array}$ & $\begin{array}{c}1064 \mathrm{~nm} \\
1.5 \mathrm{~J} / \mathrm{cm}^{2} \\
\text { Pulsed } \\
50 \text { and } 70 \mathrm{~Hz} \\
1.4 \mathrm{~W} \\
20 \mathrm{~mJ} \\
10 \mathrm{~s}\end{array}$ & $\begin{array}{c}\text { Laser irradiation did not affect cell viability but } \\
\text { significant increased proliferation at } 48 \mathrm{~h} \text {. } \\
\text { Laser irradiation significantly induced the expression } \\
\text { of } A L P L, R U N X 2 \text {, and } S P P 1 \text { on day } 7 . \\
\text { Laser irradiation increased the intracellular } \mathrm{Ca}^{2+} \\
\text { levels through the activation of transient receptor } \\
\text { potential } 1 \text { (TRPC1) ion channels. }\end{array}$ \\
\hline [77] & Nd:YAG & Saos-2 & $\begin{array}{l}2018 \\
\text { Kara, et al. }\end{array}$ & $\begin{array}{c}1064 \mathrm{~nm} \\
\text { Pulsed } \\
5,10,20 \text {, and } 30 \mathrm{~Hz} \\
0.5,1,2 \text {, and } 3 \mathrm{~W} \\
100 \mathrm{~mJ} \\
30 \mathrm{~s}\end{array}$ & $\begin{array}{l}\text { The proliferation rates on day } 4 \text { increased as the } \\
\text { number of applications increased, especially in those } \\
\text { cases in which the irradiation was performed } 2 \text { or } \\
3 \text { times more. }\end{array}$ \\
\hline [78] & Nd:YAG & Saos-2 & $\begin{array}{c}2019 \\
\text { Tsuka, et al. }\end{array}$ & $\begin{array}{c}1064 \mathrm{~nm} \\
10.34 \mathrm{~J} / \mathrm{cm}^{2} \\
10 \mathrm{pps} \\
0.3 \mathrm{~W} \\
30 \mathrm{~mJ} \\
60 \mathrm{~s}\end{array}$ & $\begin{array}{l}\text { Laser irradiation accelerated migration of cells until } \\
24 \mathrm{~h} \text {, significant enhancement of ATP production. }\end{array}$ \\
\hline
\end{tabular}


Table 1. Cont

\begin{tabular}{|c|c|c|c|c|c|}
\hline Reference No. & Laser & Cell & Year Author & Irradiation Protocol & Major Findings \\
\hline [79] & Nd:YAG & Saos-2 & $\begin{array}{c}2020 \\
\text { Tsuka, et al. }\end{array}$ & $\begin{array}{c}1064 \mathrm{~nm} \\
\text { 5.17, 17.23, } 34.47 \text {, and } 51.7 \mathrm{~J} / \mathrm{cm}^{2} \\
\text { Pulsed } \\
20-30 \mathrm{~Hz} \\
0.6,2.0,4.0 \text {, and } 6.0 \mathrm{~W} \\
15 \mathrm{~s}\end{array}$ & $\begin{array}{c}\text { Laser irradiation significantly increased expression of } \\
A L P L, R A N K L, T N F R S F 11 B \text {, and RANKL/OPG ratio } \\
\text { at } 24 \mathrm{~h} .\end{array}$ \\
\hline [80] & Nd:YAG & MC3T3-E1 & $\begin{array}{c}2010 \\
\text { Kim, et al. }\end{array}$ & $\begin{array}{c}1064 \mathrm{~nm} \\
1.5,3, \text { and } 5 \mathrm{~J} / \mathrm{cm}^{2} \\
15 \mathrm{pps} \\
0.75 \mathrm{~W} \\
4-12 \mathrm{~s}\end{array}$ & $\begin{array}{c}\text { Laser irradiation significantly decreased cell } \\
\text { proliferation at day } 3 \text {, but significantly increased ALP } \\
\text { activity on day } 3,7 \text {, and } 14 \text {. } \\
\text { Laser irradiation highly intensified calcium } \\
\text { deposition at all fluences on day } 12 \text { and significantly } \\
\text { enhanced mineralization on day } 21 \text {. } \\
\text { Laser irradiation significantly increased expression of } \\
\text { Bmp2, Cbfa1, SP7, Dlx } x \text {, Igf1, and Vegf. }\end{array}$ \\
\hline [82] & Er:YAG & Saos-2 & $\begin{array}{c}2004 \\
\text { Schwarz, et al. }\end{array}$ & $\begin{array}{c}2940 \mathrm{~nm} \\
5.08,7.62,10.16 \text {, and } 12.7 \mathrm{~J} / \mathrm{cm}^{2} \\
\text { Pulsed } \\
10 \mathrm{~Hz} \\
40,60,80 \text {, and } 100 \mathrm{~mJ} \\
10 \mathrm{~s}\end{array}$ & $\begin{array}{l}\text { Mitochondrial activity increased significantly with } \\
\text { decreasing energy settings and increasing distances. }\end{array}$ \\
\hline [83] & Er:YAG & MC3T3-E1 & $\begin{array}{c}2010 \\
\text { Aleksic, et al. }\end{array}$ & $\begin{array}{c}2940 \mathrm{~nm} \\
\text { 0.7, 1.0, 1.4, 2.1, 2.9, 3.1, 3.6, } 4.3,4.7,6.4,6.7 \\
\text { 8.6, 10.8, 12.9, } 15.1 \text {, and } 17.2 \mathrm{~J} / \mathrm{cm}^{2} \\
\text { Pulsed } \\
10,20,30,40 \text {, and } 50 \mathrm{~Hz} \\
23,39,50 \text {, and } 68 \mathrm{~mJ} \\
30,60,90 \text {, and } 120 \mathrm{~s} \text { and } 2.5,3,3.5 \text {, and } 4 \mathrm{~min}\end{array}$ & 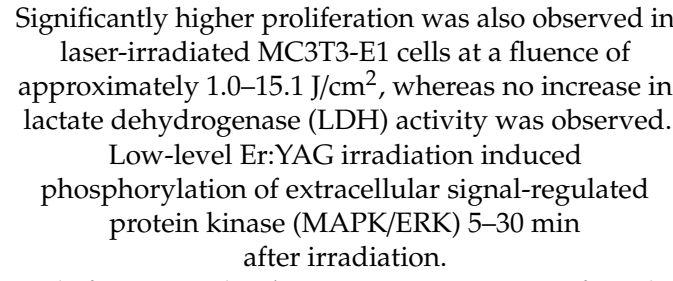 \\
\hline [84] & Er:YAG & $\begin{array}{l}\text { Rat primary calvarial } \\
\text { osteoblast-like cell, } \\
\text { MC3T3-E1 }\end{array}$ & $\begin{array}{l}2020 \\
\text { Niimi, et al. }\end{array}$ & $\begin{array}{c}2940 \mathrm{~nm} \\
2.2,3.3, \text { and } 4.3 \mathrm{~J} / \mathrm{cm}^{2} \\
\text { Pulsed } \\
20 \mathrm{~Hz} \\
17.6,26.4 \text {, and } 34.5 \mathrm{~mJ} \\
60 \mathrm{~s} \\
\end{array}$ & $\begin{array}{c}\text { Calcification and Bglap expression were significantly } \\
\text { increased after Er:YAG laser irradiation at } 3.3 \mathrm{~J} / \mathrm{cm}^{2} . \\
\text { Laser irradiation at } 3.3 \mathrm{~J} / \mathrm{cm}^{2} \text { caused upregulation of } \\
\text { inflammation-related genes, downregulation of Wisp2 } \\
\text { and enrichment of inflammation-related and Notch } \\
\text { signaling gene sets. }\end{array}$ \\
\hline [88] & $\mathrm{CO}_{2}$ & $\begin{array}{l}\text { Rat osteoblast-like } \\
\text { ROS17/2.8 cells }\end{array}$ & $\begin{array}{c}2011 \\
\text { Sasaki, et al. }\end{array}$ & $\begin{array}{c}0.357,0.715,1.07 \text {, and } 1.43 \mathrm{~J} / \mathrm{cm}^{2} \\
0.5,1,1.5 \text {, and } 2 \mathrm{~W} \\
20 \mathrm{~s}\end{array}$ & $\begin{array}{l}\text { Ibsp mRNA levels were increased at } 12 \mathrm{~h} \text { after } \\
\text { irradiation at } / .1 .43 \mathrm{~J} / \mathrm{cm}^{2} .\end{array}$ \\
\hline
\end{tabular}




\subsection{Diode Laser}

Diode lasers are representative lasers used in PBM for wound healing, and their biostimulatory effects, such as anti-inflammatory effects, have been reported in previous studies [4]. To determine the physiological mechanisms related to the biological effects, lipopolysaccharide (LPS)-challenged human gingival fibroblasts (HGFs) were irradiated using an $830 \mathrm{~nm}$ diode laser, with a total energy of 1.9-12.6 J corresponding to 3-20 min exposure, and $\mathrm{PGE}_{2}$ production and cyclooxygenase (COX)-1 (COX1) and COX-2 (COX2) gene expression were analyzed. The results suggested that $\mathrm{PGE}_{2}$ production and COX-2 mRNA levels were significantly suppressed in a dose-dependent manner upon laser exposure [94]. Additionally, dramatic downregulation of plasminogen activator (PA) activity, implicated in the degradation of extracellular matrix and synthesis of kinin in the process of inflammation, and downregulation of tissue PA mRNA levels were observed in the HGFs irradiated with $830 \mathrm{~nm}$ laser at $7.9 \mathrm{~J} / \mathrm{cm}^{2}$ compared to that in the control group [95]. In addition, under similar conditions, interleukin (IL)-1 $\beta$ production was reduced, and further investigation by RT-PCR showed that mRNA expression of IL-1 $\beta$ was inhibited, whereas that of IL- $1 \beta$-converting enzyme (ICE) was invariable [96].

The effect of diode laser on the proliferation and migration of fibroblasts has been reported previously [97-99], and the exposure time is more relevant to cell proliferation and cell survival than to power output [97]. Moreover, the cell proliferation rates in the single-dose and double-dose groups were compared using a $685 \mathrm{~nm}$ diode laser. Although cell proliferation was enhanced in both groups, no significant difference was observed between the two laser-irradiated groups. In addition, a single dose of $2.0 \mathrm{~J} / \mathrm{cm}^{2}$ in the irradiated group resulted in a higher proliferation and viability rate than the nonirradiated control group. They also evaluated the secretion of growth factors such as basic fibroblast growth factor (bFGF), IGF-1, and the receptor of IGF-1 (IGFBP3). Single-dose irradiation significantly increased the secretion of bFGF and IGF-1 in irradiated cells, but the secretion of IGFBP3 was not significantly increased compared to that in control cells. All growth factors were significantly increased in the double-dose group compared to the nonirradiated group [100]. Similar to this result, the upregulation of mRNA expression for other growth factors such as IGF, VEGF, and TGF- $\beta$ has also been confirmed [101-103]. In contrast, irradiation with an $810 \mathrm{~nm}$ laser caused a dramatic reduction in HGF cell numbers in vitro, with variable parameters, i.e., fluence of $24.6-492.8 \mathrm{~J} / \mathrm{cm}^{2}$ [104].

Diode lasers have also been reported to have positive effects on collagen synthesis [102]. Investigation of the effect of a $904 \mathrm{~nm}$ diode laser on cell growth and procollagen synthesis of NIH-3T3 fibroblasts was approximately three- to sixfold after irradiation with 3 and $4 \mathrm{~J} / \mathrm{cm}^{2}$, although no significant increase in procollagen synthesis was observed. However, neither cell growth nor procollagen synthesis was observed at $5 \mathrm{~J} / \mathrm{cm}^{2}$ [105]. In contrast, in another study, gene expression of collagen type 1 was upregulated in the HGF cell line (HGF3-PI 53) 3 days after irradiation (4 J/cm²) [99].

To examine the laser's effect on fibroblast-myofibroblast differentiation, NIH/3T3 fibroblasts were irradiated with a $635 \mathrm{~nm}$ diode laser at $0.3 \mathrm{~J} / \mathrm{cm}^{2}$, and morphological, biochemical, and electrophysiological assays were conducted. Expression of matrix metalloproteinase (MMP)-2 and MMP-9 (MMPs play a pivotal role in physiological processes such as tissue remodeling) was upregulated, whereas tissue inhibitors of MMPs (TIMP)-1 and TIMP-2 were suppressed. Additionally, TGF- $\beta 1 /$ Smad3-mediated fibroblast-myoblast transition was inhibited. These results suggest that the diode laser modulates the TRPC1 ion channel, which in turn contributes to an antifibrotic effect by interfering with TGF- $\beta 1$ signaling [106].

Bisphosphonate treatment is known to have a negative effect on wound healing [107]. In a study, diode laser irradiation tended to increase the viability of HGFs, although no significant difference was observed compared to that of nonirradiated control HGFs. However, when HGFs were cultured in a bisphosphonate-conditioned medium, laser irradiation significantly increased cell viability. Furthermore, laser irradiation on cell-free bisphosphonate-conditioned medium before culturing HGFs had no significant effect on cell viability, which indicated that laser irradiation directly affected the HGFs rather than suppressing the medicinal effect of bisphosphonate [43]. Thus, diode lasers may 
have the potential to become a supportive tool for preventing and treating of bisphosphonate-related diseases, such as osteonecrosis of the jaw.

However, adverse effects of lasers have also been reported. Diode laser irradiation (904 nm) at $3 \mathrm{~J} / \mathrm{cm}^{2}$ on fibroblast cell line changed the ultrastructure of the cells' cytoplasmic organelles; concurrently, a significant reduction in protein synthesis was observed [108]. Therefore, the cytotoxicity of the lasers should also be investigated for their safe usage.

\subsection{Nd:YAG Laser}

Previous studies have indicated that Nd:YAG lasers have various biological effects on cells, both in vivo and in vitro [4]. Nd:YAG laser (wavelength: $1060 \mathrm{~nm}$ ) reduced collagen synthesis in human skin fibroblasts at energy levels as low as $1.1 \times 10^{3} \mathrm{~J} / \mathrm{cm}^{2}$, without altering DNA replication or cell viability [109]. Furthermore, DNA replication and collagen synthesis in human skin fibroblasts have been compared between Nd:YAG laser irradiation at $1.2-4.7 \times 10^{3} \mathrm{~J} / \mathrm{cm}^{2}$ for $3-12 \mathrm{~s}$ and under halogen lamp heat. Marked inhibition of DNA replication and collagen production was observed in the laser-irradiated fibroblasts, although no such decrease was noted in the halogen lamp-heated fibroblasts. Therefore, several characteristics other than the thermal effect may be critical in altering the biological functions of fibroblasts [110].

Nevertheless, histological analysis of laser-treated skin areas showed new collagen formation and increased the number of fibroblasts [111]. In addition, many other studies showed an increase in procollagen and collagen type-1 levels after Nd:YAG laser irradiation [76,112-115]. Nd:YAG laser downregulated the expression of MMP-1 and MMP-2 enzymes in the injured skin [112]. The reduction in MMP-1 was observed in keratinocyte-fibroblasts after Q-switched Nd:YAG laser irradiation at $8 \mathrm{~J} / \mathrm{cm}^{2}$ [113]. Moreover, the effects of different wavelengths (532 $\mathrm{nm}$ and $1064 \mathrm{~nm}$ ) of a Q-switched Nd:YAG laser on human skin fibroblasts were investigated. Both the lasers significantly increased the expression of type I and III procollagen and tissue inhibitors of metalloproteinase (TIMP)- 1 and TIMP-2 and decreased MMP-2 and MMP-3 expression. Higher increased/decreased rates were observed in the $1064 \mathrm{~nm}$ Nd:YAG laser irradiation. Additionally, the $532 \mathrm{~nm}$ Nd:YAG laser increased Hsp70 and IL-6 expression, whereas the $1064 \mathrm{~nm}$ Nd:YAG laser upregulated TGF- $\beta$ expression, suggesting that the molecular biological effects of Nd:YAG laser irradiation may differ according to the wavelengths used [115].

\subsection{Er:YAG and Er,Cr:YSGG Lasers}

The specific absorption characteristics of Er:YAG and Er,Cr:YSGG lasers have been reported to be beneficial for wound healing after soft tissue ablation $[116,117]$. During ablation, cells underlying the surface layer, including fibroblasts, indirectly receive low energy of the Er:YAG/Er,Cr:YSGG laser irradiation, which has been shown to promote wound healing and tissue regeneration [10]. Therefore, recently, a direct effect of low-level irradiation of Er:YAG/Er,Cr:YSGG laser on fibroblasts has been investigated in vitro. Pourzarandian et al. [118] showed that low-level laser therapy using an Er:YAG laser enhanced the proliferation of cultured HGFs and identified the optimal stimulative energy density of $3.4 \mathrm{~J} / \mathrm{cm}^{2}$. They also observed a significant increase in $\mathrm{PGE}_{2}$ production and COX-2 mRNA expression after irradiation, and laser-induced $\mathrm{PGE}_{2}$ synthesis was completely inhibited by the COX-2 inhibitor, NS398 [119]. Proteomic analysis has been performed to investigate differentially expressed proteins in HGFs induced by low-level Er:YAG laser irradiation. On day 1 after irradiation at $2.1 \mathrm{~J} / \mathrm{cm}^{2}$, significant cell proliferation without cell damage was observed. In addition, a total of 377 differentially expressed proteins were identified by mass spectrometry, 59 of which were upregulated and 15 were downregulated in laser-irradiated HGFs. Among the upregulated differentially expressed proteins, galectin-7, which is one of the essential proteins in the wound-healing process, was validated by quantitative PCR, Western blotting analysis, and enzyme-linked immunosorbent assay. To confirm the effect of galectin-7, HGFs were treated with recombinant human galectin-7, and cell proliferation was assessed in a dose-dependent manner, which suggested that alteration in protein expression and 
upregulation of galectin-7 may partly contribute to proliferation in HGFs [120]. Kong et al. [121] observed maximal cell proliferation at $6.3 \mathrm{~J} / \mathrm{cm}^{2}$ on day 3 after irradiation, although it was accompanied by an increase in lactate dehydrogenase (LDH) release. An increase in ATP level, Ki-67 staining, and cyclin-A2 mRNA expression was confirmed, and it was observed that the increase in cell proliferation was due to the effect of Er:YAG laser irradiation on the cell cycle. However, alterations in the mitochondria and ribosomal endoplasmic reticulum (ER) were observed at $3 \mathrm{~h}$ postirradiation at $6.3 \mathrm{~J} / \mathrm{cm}^{2}$; the changes subsided after $24 \mathrm{~h}$, suggesting the occurrence of transient cellular injury. Furthermore, as the surface temperature of laser-irradiated cells reached $40.9^{\circ} \mathrm{C}$, nonirradiated cells were treated with a medium warmed at $40{ }^{\circ} \mathrm{C}$, which also increased cell proliferation. In addition, laser-induced cell proliferation was suppressed by inhibitors of the thermosensory transient receptor potential channels (TRPV-1), capsazepine, or SKF96365. Finally, 21 genes involved in heat-related biological responses and endoplasmic reticulum-associated degradation were identified by microarray analysis. Therefore, $6.3 \mathrm{~J} / \mathrm{cm}^{2}$ laser irradiation on HGFs may enhance cell proliferation through photothermal effects, despite transient cellular damage.

The effects of Er:YAG and Er,Cr:YSGG irradiation on cultured fibroblast cell lines (NCBI:C-165) were compared at different fluences: $1 \mathrm{~W}$ power output $(10 \mathrm{~Hz}$ and $100 \mathrm{~mJ})$ and $0.5 \mathrm{~W}$ power output $(10 \mathrm{~Hz}$ and $150 \mathrm{~mJ})$, respectively. Cell proliferation was upregulated in both groups compared to that in the control, but Er,Cr:YSGG laser irradiation tended to be more effective in cell proliferation than Er:YAG laser irradiation [122].

The mechanical effects of Er:YAG laser irradiation on fibroblasts have also been studied. As the number of primary human gingival fibroblasts significantly decreased after 3.0 W irradiation, gene expression analysis was conducted for cells irradiated at 0.6, 1.0, and 1.2 W. Cells were divided into four groups: control cells (not undergoing any procedures), cells undergoing only Er:YAG laser irradiation, cells undergoing only centrifugal loading, and a cells undergoing both Er:YAG laser irradiation and centrifugal force loading. Gene expression of COX2, IL1B, TNFA, BMP2, and BMP4 was significantly increased in laser-irradiated cells (in a dose-dependent manner) compared to the control cells at $24 \mathrm{~h}$ after irradiation. Additionally, only COX2 gene expression showed a significant increase in the centrifugal-loaded cells compared to control cells. In contrast, gene expression of COX2, IL1B, TNFA, $B M P 2$, and $B M P 4$ was significantly higher in the laser-loaded and centrifugally loaded cells than in the centrifugally loaded cells. These results suggest that bone metabolism genes may be regulated by mechanical stimulation and laser irradiation combined [123].

\section{4. $\mathrm{CO}_{2}$ Laser}

High-power $\mathrm{CO}_{2}$ laser irradiation is mainly used in various surgical procedures as an alternative to traditional scalpel procedures [124]. Recently, low-level laser irradiation with a $\mathrm{CO}_{2}$ laser has gained attention in dentistry due to its promotive effect on wound healing [125-127]. The secretion of TGF- $\beta 1$ was downregulated, whereas that of bFGF was upregulated by high-frequency $\mathrm{CO}_{2}$ laser irradiation, which occurred maximally at $4.7 \mathrm{~J} / \mathrm{cm}^{2}$ in both normal and keloid dermal fibroblasts in vitro, resulting in enhancement of cell replication [128]. Thus, $\mathrm{CO}_{2}$ laser irradiation may have the ability to balance collagen organization in fibrosis. Furthermore, $\mathrm{PBM}$ with a $\mathrm{CO}_{2}$ laser on proliferation and migration was examined at the cellular level. Promotion of cell proliferation and migration of cultured human dermal fibroblasts (HDFs) were examined by MTS assay and cell migration assay, respectively, with irradiation of $1.0 \mathrm{~J} / \mathrm{cm}^{2}$. In addition, with the same power, Western blotting analysis showed activation of Akt, ERK, and JNK signaling pathways. However, suppression of Akt, ERK, or JNK signaling pathways significantly inhibited both the proliferation and migration of laser-irradiated HDFs. The study indicated that low-level laser irradiation with $\mathrm{CO}_{2}$ laser might promote proliferation and migration of fibroblasts via activation of Akt, ERK, or JNK signaling pathways [129].

From another perspective, as the clinical use of $\mathrm{CO}_{2}$ lasers has increased, the safety of laser irradiation has been investigated. Apfelberg et al. [130] exposed cultured fibroblasts to $\mathrm{CO}_{2}$ laser irradiation before the occurrence of malignancy was examined. The results showed that $\mathrm{CO}_{2}$ 
laser-irradiated cells did not exhibit a greater incidence of malignancy compared to controls, indicating that $\mathrm{CO}_{2}$ laser seems to be noncarcinogenic in laboratory cells.

\subsection{Summary}

The contents of this section are summarized in Table 2. The effects of PBM by laser irradiation on fibroblasts appear to be comparable despite the different wavelengths. Proliferation, migration, and secretion of cytokines/chemokines are the main functions affected by laser irradiation; which may lead to early wound healing; although, the biological/molecular evidence to support this phenomenon is still partial and inadequate. Moreover, excessive power or irradiation time results in cell damage and ineffective treatment. However, concurrently, lasers have the potential to regulate collagen synthesis through fibroblast stimulation depending on the target disease. Thus, further investigation on optimal configuration, which is consistent in vivo and in vitro, and more profound bioinformatic studies are required in the future to clarify the critical mechanisms of the effects of lasers on fibroblasts.

Table 2. Summary of the effects of laser irradiation on fibroblasts.

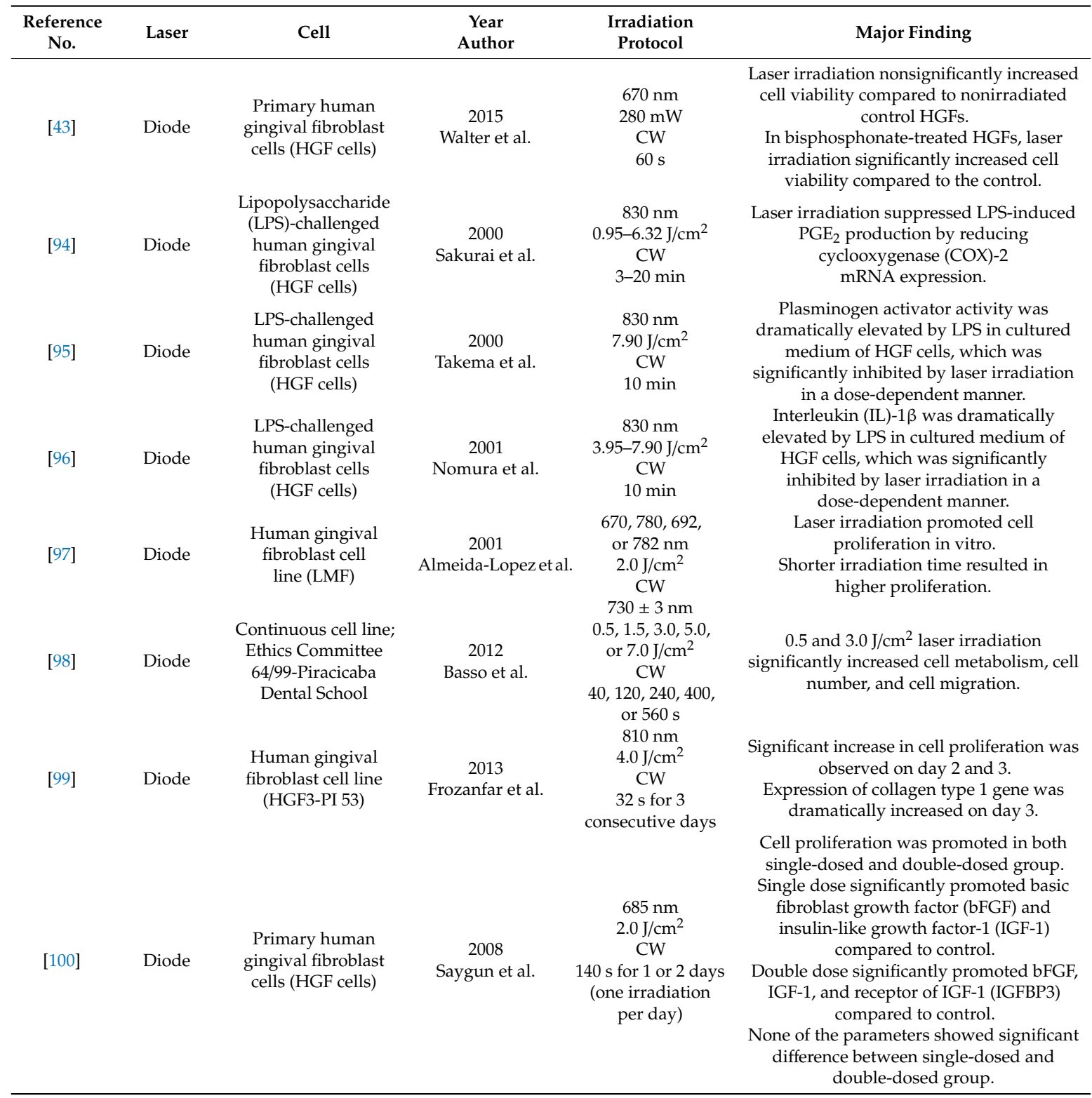


Table 2. Cont.

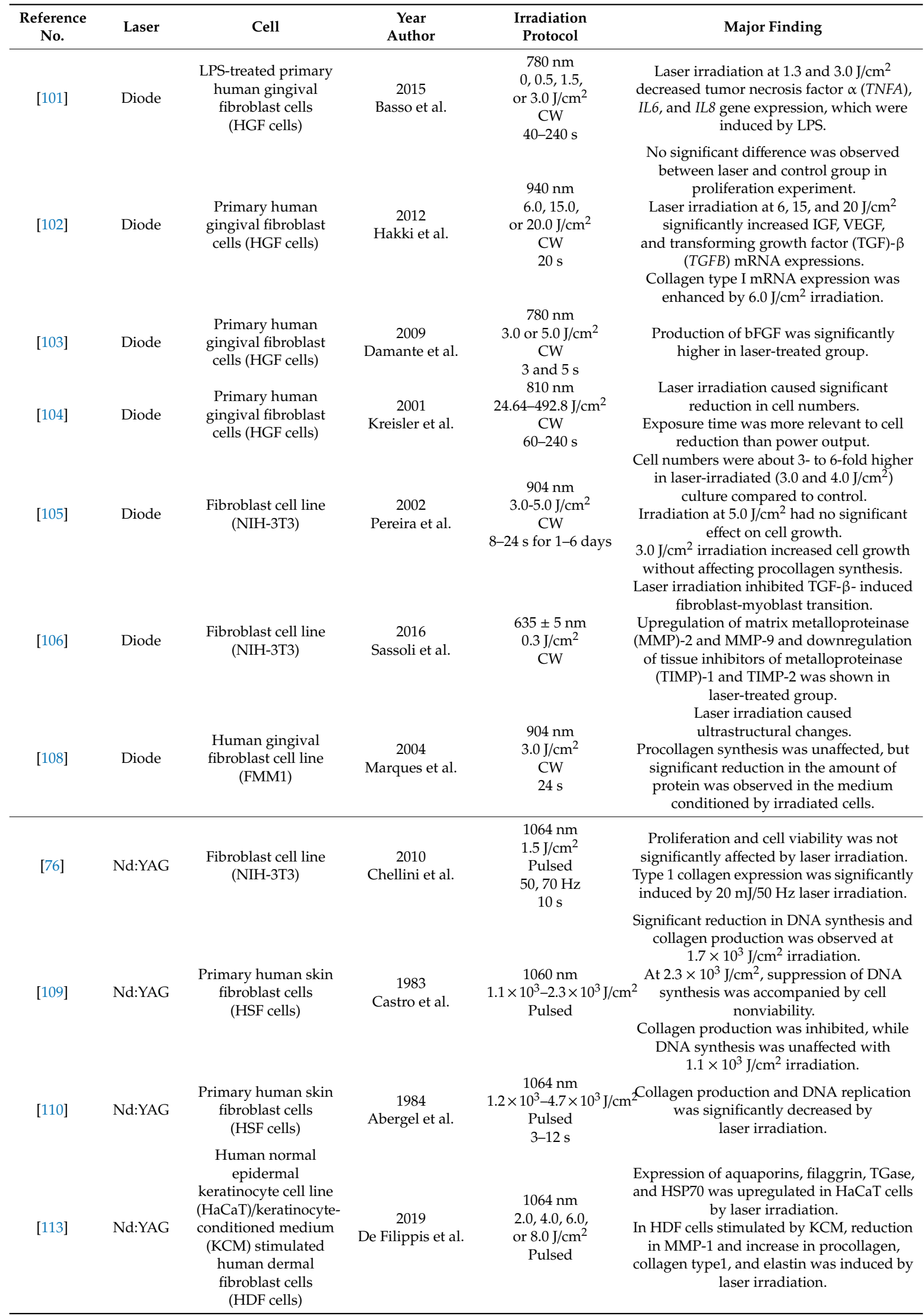


Table 2. Cont.

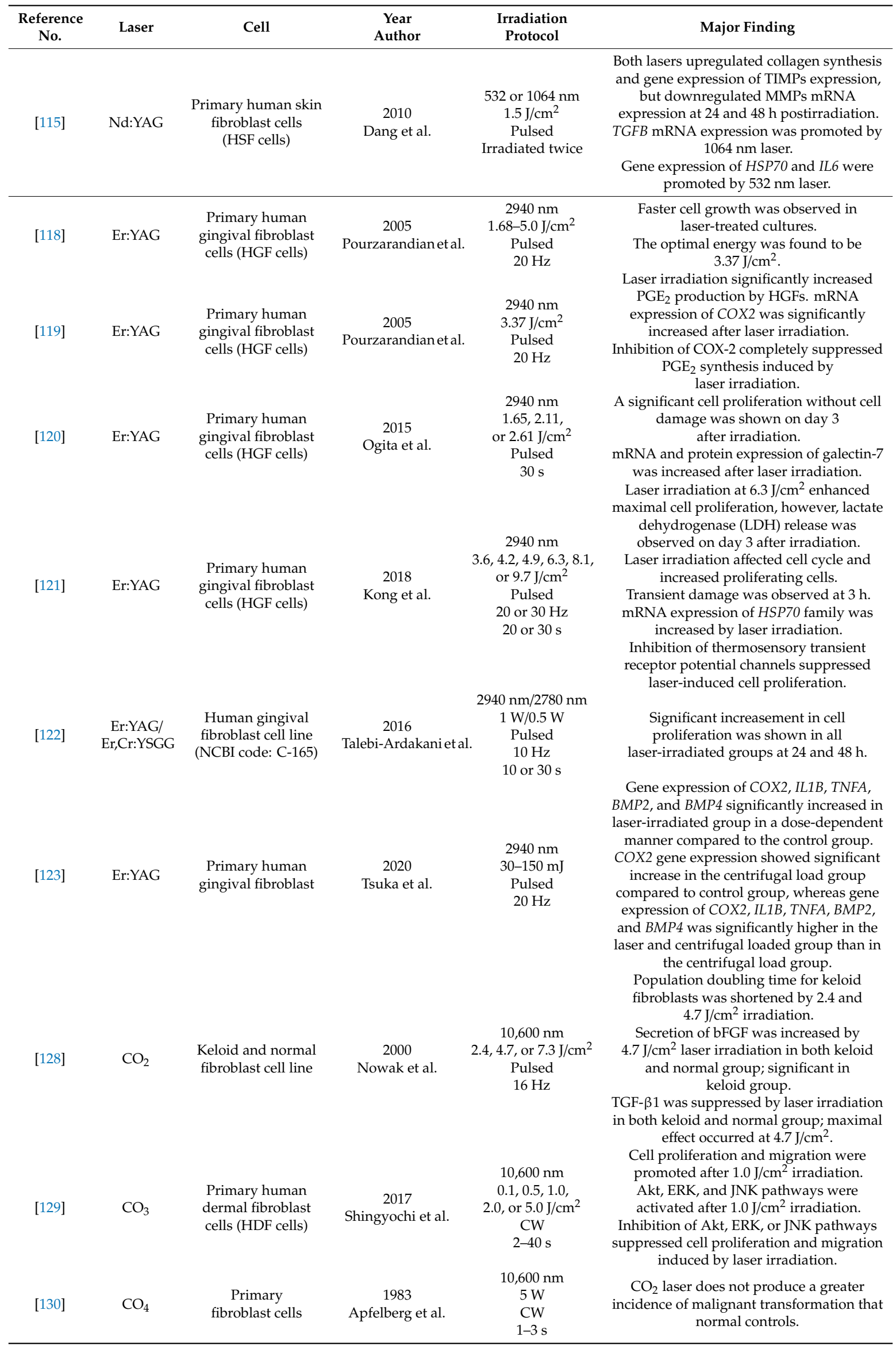




\section{Effects of Laser Irradiation on Periodontal Ligament Cells}

The periodontal ligament is the only ligament in the body that connects two distinct hard tissues. It is a fibrous, complex, and soft connective tissue that attaches the tooth root to the inner wall of the alveolar bone. The periodontal ligament thickness decreases with age. It is functionally essential for tooth support and for allowing teeth to withstand the forces generated during mastication [131].

\subsection{Diode Laser}

Diode laser irradiation has been reported to have positive effects on human periodontal ligament cells (hPDLCs). PBM at energy doses of 2 and $4 \mathrm{~J} / \mathrm{cm}^{2}$ upregulated gene expression related to osteogenic differentiation, including BMP2, OC (BGLAP), RUNX2, and ALPL in hPDLCs. PBM enhanced the osteogenic differentiation of hPDLCs via cAMP regulation [132]. Additionally, it significantly increased cellular viability, decreased cellular inflammatory marker expression, and increased OC activity in hPDLCs at two energy densities $\left(5\right.$ and $10 \mathrm{~J} / \mathrm{cm}^{2}$ ) [133]. Suppression of inflammation is one of the positive effects of laser irradiation. After $670 \mathrm{~nm} \mathrm{Ga-Al-As} \mathrm{laser} \mathrm{irradiation} \mathrm{(} 5$ and $\left.10 \mathrm{~J} / \mathrm{cm}^{2}\right)$, the $\mathrm{mRNA}$ expression of inducible NO synthase (INOS), COX2, and IL1B were decreased compared to that in nonirradiated control cells.

Another study using an $830 \mathrm{~nm}$ laser showed that laser irradiation at $3.8 \mathrm{~J} / \mathrm{cm}^{2}$ decreased COX-2 and cytosolic phospholipase $\mathrm{A}_{2}-\alpha$ mRNA expression after $24 \mathrm{~h}$ in mechanically stretched hPDLCs [134]. The increase in $\mathrm{PGE}_{2}$ production was significantly inhibited by diode laser irradiation at $346-1152 \mathrm{~J} / \mathrm{cm}^{2}$ in a dose-dependent manner. The increase in IL-1 $\beta$ production was also significantly inhibited by diode laser irradiation, although the inhibition was observed only with high-power irradiation [135]. Diode laser irradiation (4.0-7.9 J/ $\left.\mathrm{cm}^{2}\right)$ significantly inhibited a marked increase in plasminogen activator activity in hPDLCs in response to stretching [136]. Additionally, Huang et al. [137] reported that the gene expression levels of INOS, TNFA, and IL1B in LPS-exposed periodontal ligament cells were decreased after irradiation, and phospho-ERK expression was significantly increased in the laser-irradiated cells compared to that in nonirradiated cells.

hPDLCs irradiated with an $810 \mathrm{~nm}$ diode laser, showed promotion of proliferation and differentiation. Irradiation at $3.9 \mathrm{~J} / \mathrm{cm}^{2}$ increased proliferation of human periodontal ligament fibroblasts (PDLFs) between 24 and $48 \mathrm{~h}$, and ALP activity at 48 and $72 \mathrm{~h}$. The phosphorylated ERK level was also more prominent after irradiation at $3.9 \mathrm{~J} / \mathrm{cm}^{2}$ energy fluency [138]. Additionally, the protein expression of MMP-8 in hPDLFs was decreased by $810 \mathrm{~nm}$ diode laser irradiation at $10 \mathrm{~J} / \mathrm{cm}^{2}$ [139]. Moreover, the $809 \mathrm{~nm}$ diode laser irradiation at $2.0-7.8 \mathrm{~J} / \mathrm{cm}^{2}$ of PDLFs significantly upregulated their proliferation up to $72 \mathrm{~h}[140]$.

\subsection{Er:YAG Laser}

Er:YAG laser irradiation at $4.2 \mathrm{~J} / \mathrm{cm}^{2}$ on hPDLFs promoted cell proliferation, migration, and invasion abilities. The report also revealed that the silencing of galectin-7 abrogated the effects of Er:YAG laser on cell proliferation, migration, and invasion, suggesting that the Er:YAG laser promoted these effects through the induction of galectin-7 [141].

\subsection{Nd:YAG Laser, Er,Cr:YSGG Laser, and $\mathrm{CO}_{2}$ Laser}

There are no reports on the effects of Nd:YAG laser, Er,Cr:YSGG laser, and $\mathrm{CO}_{2}$ laser irradiation on periodontal ligament cells.

\subsection{Summary}

The contents of this section are summarized in Table 3. Laser irradiation on PDLs enhanced cell proliferation, migration, calcification, and differentiation. In addition, gene expression was altered by laser irradiation, especially with suppression of inflammatory products. However, the effects of laser irradiation on hPDLCs and hPDLFs were only investigated using diode and Er:YAG lasers. 
It is necessary to generate more evidence and reveal the mechanisms by which laser irradiation affects hPDLCs.

Table 3. Summary of the effects of laser irradiation on human periodontal ligament cells.

\begin{tabular}{|c|c|c|c|c|c|}
\hline $\begin{array}{l}\text { Reference } \\
\text { No. }\end{array}$ & Laser & Cell & $\begin{array}{c}\text { Year } \\
\text { Author }\end{array}$ & $\begin{array}{l}\text { Irradiation } \\
\text { Protocol }\end{array}$ & Major Finding \\
\hline [132] & Diode & $\begin{array}{l}\text { Human periodontal } \\
\text { ligament cells } \\
\text { (hPDLCs) }\end{array}$ & $\begin{array}{c}2013 \\
\text { Wu, et al. }\end{array}$ & $\begin{array}{c}660 \mathrm{~nm} \\
1,2, \text { or } 4 \mathrm{~J} / \mathrm{cm}^{2} \\
\mathrm{CW} \\
66,132, \text { or } 264 \mathrm{~s}\end{array}$ & $\begin{array}{l}\text { Laser irradiation significantly promotes } \\
\text { proliferation of hPDLCs. } \\
\text { Laser irradiation enhanced the mRNA } \\
\text { expression of osteogenic maker genes. }\end{array}$ \\
\hline [133] & Diode & $\begin{array}{l}\text { Periodontal ligament } \\
\text { cell line }\end{array}$ & $\begin{array}{c}2014 \\
\text { Huang, et al. }\end{array}$ & $\begin{array}{c}670 \mathrm{~nm} \\
5, \text { or } 10 \mathrm{~J} / \mathrm{cm}^{2} \\
\mathrm{CW} \\
2.5, \text { or } 5 \mathrm{~s}\end{array}$ & $\begin{array}{c}\text { Laser irradiation significantly decreased the } \\
\text { protein expressions of inflammatory makers. } \\
\text { The protein expression of osteocalcin was } \\
\text { significantly increased in } \\
\text { laser-irradiated cells. }\end{array}$ \\
\hline [134] & Diode & $\begin{array}{l}\text { Human periodontal } \\
\text { ligament cells } \\
\text { (hPDLCs) }\end{array}$ & $\begin{array}{c}2010 \\
\text { Mayahara, et al. }\end{array}$ & $\begin{array}{l}830 \mathrm{~nm} \\
3.82 \mathrm{~J} / \mathrm{cm}^{2} \\
\mathrm{CW} \\
10 \mathrm{~min}\end{array}$ & $\begin{array}{c}\text { Laser irradiation significantly inhibited } \\
\text { cyclooxygenase }(C O X)-2 \text { and cytosolic } \\
\text { phospholipase } A_{2}-\alpha(P L A 2 G 4 A) \\
\text { mRNA expression. }\end{array}$ \\
\hline [135] & Diode & $\begin{array}{l}\text { Stretched Human } \\
\text { periodontal } \\
\text { ligament cells } \\
\text { (hPDLCs) }\end{array}$ & $\begin{array}{c}1995 \\
\text { Shimizu, et al. }\end{array}$ & $\begin{array}{c}830 \mathrm{~nm} \\
346-1152 \mathrm{~J} / \mathrm{cm}^{2} \\
\mathrm{CW} \\
0,3,6, \text { or } 10 \mathrm{~min}\end{array}$ & $\begin{array}{l}\text { The protein expression of prostaglandin } \mathrm{E}_{2} \\
\text { was significantly decreased in } \\
\text { laser-irradiated cells. } \\
\text { Laser irradiation was tended to decrease the } \\
\text { protein expression of interleukin (IL) } 1-\beta .\end{array}$ \\
\hline [136] & Diode & $\begin{array}{l}\text { Human periodontal } \\
\text { ligament cells } \\
\text { (hPDLCs) }\end{array}$ & $\begin{array}{c}1997 \\
\text { Ozawa, et al. }\end{array}$ & $\begin{array}{c}830 \mathrm{~nm} \\
3.95-7.90 \mathrm{~J} / \mathrm{cm}^{2} \\
\mathrm{CW} \\
10 \text { or } 20 \mathrm{~min} / \text { day }\end{array}$ & $\begin{array}{l}\text { Laser irradiation in a dose-dependent } \\
\text { manner significantly inhibited the } \\
\text { plasminogen activator (PA) activity in } \\
\text { hPDLCs with stretching. }\end{array}$ \\
\hline [137] & Diode & $\begin{array}{l}\text { Periodontal ligament } \\
\text { cell line }\end{array}$ & $\begin{array}{c}2013 \\
\text { Huang, et al. }\end{array}$ & $\begin{array}{c}920 \mathrm{~nm} \\
5-10 \mathrm{~J} / \mathrm{cm}^{2} \\
\mathrm{CW} \\
2.5, \text { or } 5 \mathrm{~s}\end{array}$ & $\begin{array}{l}\text { The mRNA and protein expressions of } \\
\text { inducible NO synthase (iNOS), TNF-a, IL-1 } \\
\text { was decreased in lipopolysaccharide-exposed } \\
\text { periodontal ligament cells after } \\
\text { laser irradiation. } \\
\text { The protein expression of pErk was } \\
\text { significantly increased in the laser-irradiated } \\
\text { cells compared with the nonirradiated cells. }\end{array}$ \\
\hline [138] & Diode & $\begin{array}{l}\text { Human periodontal } \\
\text { ligament fibroblasts }\end{array}$ & $\begin{array}{c}2010 \\
\text { Choi, et al. }\end{array}$ & $\begin{array}{c}810 \mathrm{~nm} \\
1.97,3.94 \\
\text { or } 5.91 \mathrm{~J} / \mathrm{cm}^{2} \\
\mathrm{CW} \\
10,20, \text { or } 30 \mathrm{~s}\end{array}$ & $\begin{array}{l}\text { Proliferation, alkaline phosphatase activity, } \\
\text { and phosphorylated ERK level were } \\
\text { significantly increased in laser-irradiated cell } \\
\text { at limited time point. }\end{array}$ \\
\hline [139] & Diode & $\begin{array}{l}\text { Human periodontal } \\
\text { ligament fibroblasts }\end{array}$ & $\begin{array}{c}2020 \\
\text { Dehdashtizadeh, et al. }\end{array}$ & $\begin{array}{l}810 \mathrm{~nm} \\
10 \mathrm{~J} / \mathrm{cm}^{2} \\
\mathrm{CW} \\
5 \mathrm{~s} / \text { day }\end{array}$ & $\begin{array}{l}\text { Laser irradiation reduced the protein } \\
\text { expression of matrix } \\
\text { metalloproteinase (MMP)- } 8 \text {. }\end{array}$ \\
\hline [140] & Diode & $\begin{array}{l}\text { Human periodontal } \\
\text { ligament fibroblasts }\end{array}$ & $\begin{array}{l}2003 \\
\text { Kreisler, et al. }\end{array}$ & $\begin{array}{c}809 \mathrm{~nm} \\
1.96,3.92 \\
\text { or } 7.84 \mathrm{~J} / \mathrm{cm}^{2} \\
\mathrm{CW} \\
75,150, \text { or } 300 \mathrm{~s}\end{array}$ & $\begin{array}{l}\text { The proliferation rates of laser-irradiated } \\
\text { culture were significant up to } 72 \mathrm{~h} \text { compared } \\
\text { to control culture. }\end{array}$ \\
\hline [141] & Er:YAG & $\begin{array}{l}\text { Human periodontal } \\
\text { ligament cells } \\
\text { (hPDLCs) }\end{array}$ & $\begin{array}{c}2020 \\
\text { Lin, et al. }\end{array}$ & $\begin{array}{c}2940 \mathrm{~nm} \\
3.6,4.2, \\
\text { or } 6.3 \mathrm{~J} / \mathrm{cm}^{2} \\
\text { Pulsed } \\
20 \mathrm{~Hz} \\
75,150, \text { or } 300 \mathrm{~s}\end{array}$ & $\begin{array}{c}\text { The proliferation, migration, and invasion } \\
\text { abilities were induced through the } \\
\text { upregulation of galectin-7 after } \\
\text { laser irradiation. }\end{array}$ \\
\hline
\end{tabular}

\section{Effects of Laser Irradiation on Endothelial Cells}

The mechanisms related to the effects of laser irradiation on wound healing are not completely clear. However, some studies reported that laser treatment could accelerate wound healing, especially in acute, chronic, and impaired wound-healing conditions [142] as well as in periodontal disease [143]. Endothelial cells play important roles in the process of wound healing and regeneration of periodontal tissue [144]. Hence, in this section, we summarized the direct effects of laser irradiation on endothelial cells. 


\subsection{Diode Laser}

Some researchers have investigated the effect of diode laser irradiation on endothelial cells. The human vascular endothelial cell line (HECV) irradiated with an $808 \mathrm{~nm}$ diode laser $\left(60 \mathrm{~J} / \mathrm{cm}^{2}\right)$ demonstrated no significant difference in viability but demonstrated higher proliferation than non-treated cells. Moreover, the study reported that diode laser stimulated mitochondrial oxygen consumption and ATP synthesis in HECV [145]. Another study using the $808 \mathrm{~nm}$ diode laser reported that CD54, CD62E, monocyte chemotactic protein-1 (MCP-1) expression, and von Willebrand factor release were altered in human umbilical vein endothelial cells (HUVECs) stimulated with IL-1 $\beta$ followed by laser irradiation. MCP-1 expression in HUVECs was significantly lower $6 \mathrm{~h}$ after $4.5 \mathrm{~J} / \mathrm{cm}^{2}$ stimulation than in IL-1 $\beta$ stimulated cells. In addition, both 1.5 and $4.5 \mathrm{~J} / \mathrm{cm}^{2}$ of laser irradiation inhibited IL-1 $\beta$-induced increase in CD54 and CD62E concentration in the supernatant. Therefore, this study suggested that low-power laser irradiation decreased the pro-inflammatory and procoagulant activity of IL-1 $\beta$-stimulated endothelial cells [146]. Moreover, a $670 \mathrm{~nm}$ diode laser irradiation caused a stimulatory effect on the proliferation of HUVECs [147] and increased their viability [43]. Using a $635 \mathrm{~nm}$ diode laser at different doses $\left(2,4\right.$, and $\left.8 \mathrm{~J} / \mathrm{cm}^{2}\right)$, all doses of irradiation significantly increased the proliferation of HUVECs and significantly reduced the concentration of soluble vascular endothelial growth factor (sVEGFR-1), an inhibitor of vascular endothelial growth factor (VEGF), compared with nonirradiated cells [148]. A study using rhesus macaque choroid-retinal endothelial cells $(\mathrm{RF} / 6 \mathrm{~A})$ reported that an $810 \mathrm{~nm}$ diode laser (over $84.0 \mathrm{~J} / \mathrm{cm}^{2}$ ) irradiation caused significant cell death, and irradiation at a fluence of 45.9-76.4 J/ $\mathrm{cm}^{2}$ induced Hsp70 hyperexpression at $12-18 \mathrm{~h}$ postirradiation [149].

\subsection{Nd:YAG Laser}

Some studies have reported the effect of Nd:YAG laser irradiation on endothelial cells. A significant induction in vinculin expression, a focal adhesion protein involved in cell adhesion and migration, in human endothelial H-end cells was observed in the Nd:YAG-irradiated (fluence, $1.5 \mathrm{~J} / \mathrm{cm}^{2}$ ) cells. Moreover, this study showed that Nd:YAG laser irradiation did not affect cell viability and stimulated cell growth [76]. In another study, cultured rat aortic endothelial cells at $5 \mathrm{~h}$ after Nd:YAG $\left(1.6 \mathrm{~J} / \mathrm{cm}^{2}\right)$ laser irradiation were examined using a DNA array chip. This study showed that 20 genes in laser-treated cells were upregulated by more than four-fold compared to those in the control, and Nd:YAG laser irradiation also upregulated gene expression related to cell migration, cell structure neurotransmission, and inflammation [150]. Moreover, Nd:YAG laser irradiation $\left(1.5 \mathrm{~J} / \mathrm{cm}^{2}\right)$ of HUVECs cultured on titanium disks coated with Porphyromonas gingivalis LPS caused downregulation of endothelial adhesion molecules, including that of intercellular adhesion molecule-1 (ICAM-1) and vascular cell adhesion molecule (VCAM) levels compared to nonirradiated HUVECs [151].

\section{3. $\mathrm{Er}: Y A G, E r, \mathrm{Cr}: Y S G G$, and $\mathrm{CO}_{2}$ Lasers}

There are no reports on the direct effects of irradiation on endothelial cells. Therefore, the molecular biological effects of Er:YAG, Er,Cr:YSGG, and $\mathrm{CO}_{2}$ laser irradiation on endothelial cells are not apparent to date.

\subsection{Summary}

The contents of this section are summarized in Table 4 . In conclusion, studies on the molecular biological effects on endothelial cells using lasers have not been so much reported and are inconclusive. Further research is needed to reveal the effects of diode lasers on endothelial cells. 
Table 4. Summary of the effects of laser irradiation on endothelial cells.

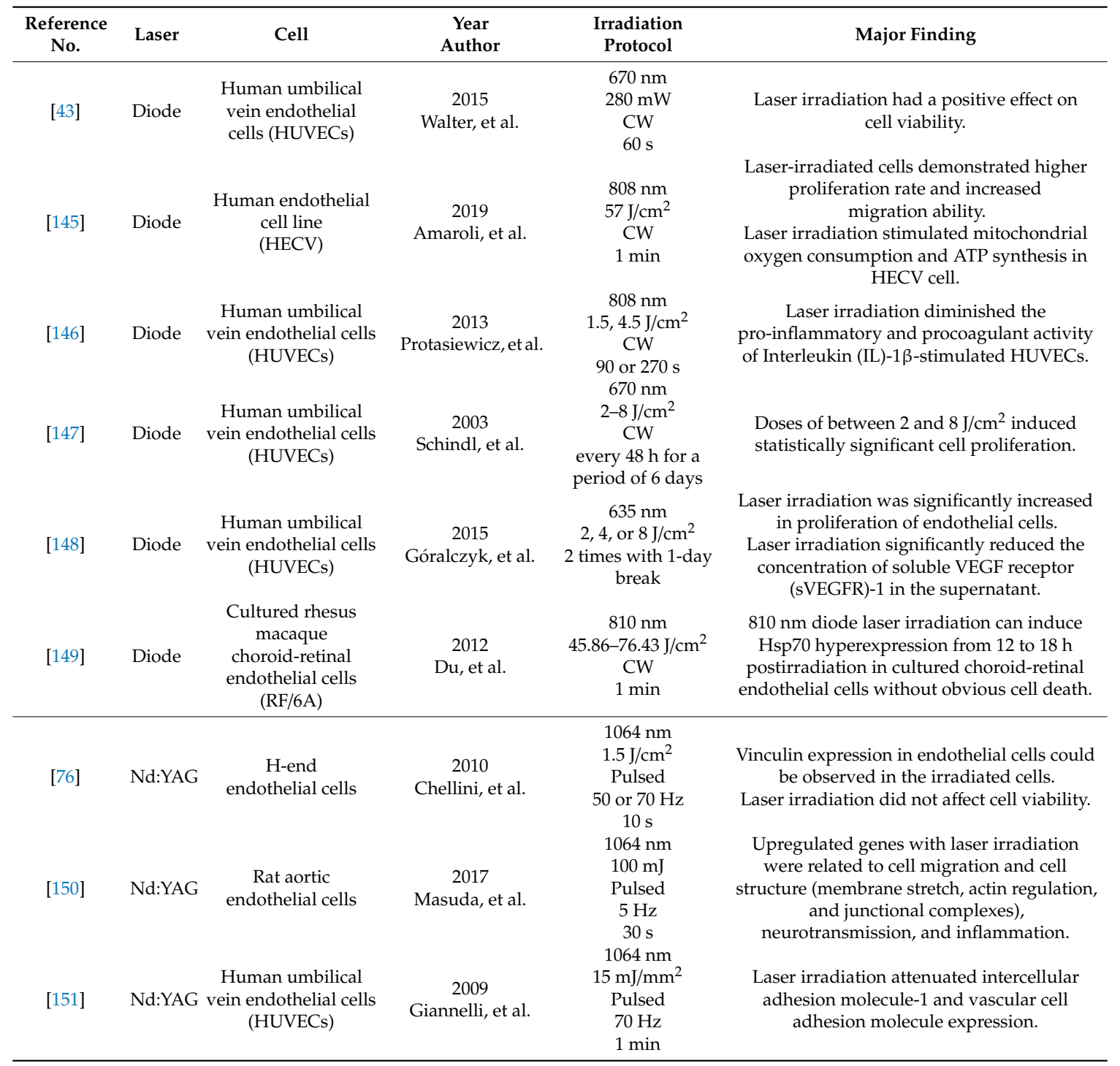

\section{Effects of Laser Irradiation on Cementoblasts}

Cementum is a unique, avascular, and mineralized tissue formed by cementoblasts [152]. Only one study has reported the effects of laser irradiation on cementoblasts. Diode laser irradiation at $940 \mathrm{~nm}$ was performed on root plate- or microplate-seeded cementoblasts at a fluence of $18 \mathrm{~J} / \mathrm{cm}^{2}$. Cell proliferation was not different until $96 \mathrm{~h}$, but laser irradiation significantly retarded the decrease in cell proliferation after $96 \mathrm{~h}$ compared to the untreahted control group. Additionally, Ibsp and Bglap, which are transcripts required for cementum formation, were significantly increased in laser-irradiated cells compared to nonirradiated cells. Moreover, the expression levels of Bmp-2,3,6,7 were significantly increased. These results indicate that biostimulation can be used during regenerative periodontal therapies to trigger cells with a periodontal attachment apparatus [153]. The contents of this section are summarized in Table 5. 
Table 5. Summary of the effects of laser irradiation on cementoblasts.

\begin{tabular}{|c|c|c|c|c|c|}
\hline $\begin{array}{l}\text { Reference } \\
\text { No. }\end{array}$ & Laser & Cell & $\begin{array}{c}\text { Year } \\
\text { Author }\end{array}$ & Irradiation Protocol & Major Finding \\
\hline [153] & Diode & Cementoblasts & $\begin{array}{c}2017 \\
\text { Bozkurt, et al. }\end{array}$ & $\begin{array}{c}940 \mathrm{~nm} \\
15,11.4, \text { or } 105 \mathrm{~J} / \mathrm{cm}^{2} \\
\mathrm{CW} \\
60 \mathrm{~s} / \mathrm{cm}^{2}\end{array}$ & $\begin{array}{l}\text { The mRNA expression related to only } \\
\text { cementoblast and bone morphogenetic } \\
\text { protein were increased in } \\
\text { laser-irradiated cells. }\end{array}$ \\
\hline
\end{tabular}

\section{Effects of Laser Irradiation on Epithelial Cells}

Epithelial cells are found on the surfaces of tissues and organs. Although they share some common characteristics, they vary in size, shape, and general appearance, according to their location [154]. Moreover, they protect deeper tissues against the external environment and possess secretory and supportive functions, thus contributing to homeostasis maintenance. Epithelial cells play an important role in wound healing [155]. There are many studies on the effects of laser irradiation on epithelial cells associated with various tissues [156-158], with the exception of oral tissues. Herein, we summarize the effects of laser irradiation on oral epithelial cells. To our knowledge, no research has been published regarding the effects of Nd:YAG, Er:YAG, Er,Cr:YSGG, or $\mathrm{CO}_{2}$ lasers on oral epithelial cells. Although some studies have reported increased proliferation in Nd:YAG laser-irradiated epithelial cells [77], there are no studies on oral tissues.

\subsection{Diode Laser}

Diode laser irradiation has been previously reported to enhance wound healing [159]. Diode lasers can penetrate superficial tissues to exert their effects in deeper tissues. However, epithelial cells are the first cells that receive laser energy. Thus, epithelial cells absorb the highest amount of energy compared to other underlying cells. Therefore, the effects of diode lasers have been studied in vitro on various epithelial cells, including keratinocytes [160], a keratinocyte cell line (Hacat) [161,162], epithelial adenocarcinoma (HeLa) cells [163,164], pigment epithelial cells [165-167], and human breast epithelial cell lines (SVCT and Bre80hTERT) [168]. In this section, we focus on epithelial cells or cell lines related to oral tissues.

To examine the effect of a low level diode laser irradiation on oral epithelial cells, cultured, normal human oral keratinocyte (NOKSI) cells were irradiated using an $810 \mathrm{~nm}$ diode laser in continuous wave mode for $5 \mathrm{~min}$, at a distance of $14.5 \mathrm{~cm}$. Upregulated gene and protein expression of human $\beta$ defensin-2 (HBD-2), a potent antimicrobial and wound-healing factor, were confirmed by qPCR, Western blotting, and immunostaining. Increased expression of HBD-2 was mediated by laser-activation of the TGF- $\beta 1$ pathway [169].

A pulsed diode laser has also been used for in vitro studies on epithelial cells. In a study by Ejiri et al. [170], the effect of low-level diode laser irradiation was examined on primary human gingival epithelial cells (HGECs). Using a 904-910 nm diode laser applied at a high frequency of $30 \mathrm{kHz}$ for 1-10 $\mathrm{min}$, at $5.7-56.7 \mathrm{~J} / \mathrm{cm}^{2}$, a significant increase in the proliferation of laser-irradiated cells was detected by WST- 8 assay, $24 \mathrm{~h}$ after laser irradiation. The maximum proliferative effect was observed after $5 \mathrm{~min}$ of laser irradiation. The in vitro wound-healing assay showed a dramatic increase in migration among the laser-irradiated cells. Moreover, phosphorylation of MAPK/ERK was observed at 5, 15, 60, and $120 \mathrm{~min}$ after irradiation, whereas stress-activated protein kinases/c-Jun N-terminal kinase and p38 MAPK remained unphosphorylated. These results indicate that proliferation and migration of HGECs may be promoted via activation of MAPK/ERK.

The antimicrobial effects of diode lasers have been reported previously [171]. To investigate the cellular mechanisms of these effects, human oral squamous epithelial carcinoma cell lines (Ca9-22 and SCC-25) were treated with LPS. An $805 \mathrm{~nm}$ diode laser was then used to irradiate cells in a repeated pulse mode for $60 \mathrm{~s}$ at a $1 \mathrm{~cm}$ distance. The expression of DEL1, which encodes a protein with anti-inflammatory effects, was significantly increased following laser irradiation. In contrast, LPS-induced IL-6 and IL-8 expression was significantly suppressed following laser irradiation. A significant increase in migration 
was also observed in laser-irradiated cells [172]. These results indicate a suppressive effect of laser irradiation on the inflammatory response.

\subsection{Summary}

The contents of this section are summarized in Table 6. Many studies have examined the effect of laser irradiation on the epithelium in vivo [156-158]. However, despite the importance of epithelial cells in wound healing, in vitro studies are limited, especially with regard to epithelial cells associated with oral tissues. Epithelial cells have different characteristics based on their location and associated tissues, and further investigation of oral epithelial cells is required to enable the advancement of laser therapies for use in oral wound healing.

Table 6. Summary of the effects of laser irradiation on epithelial cells.

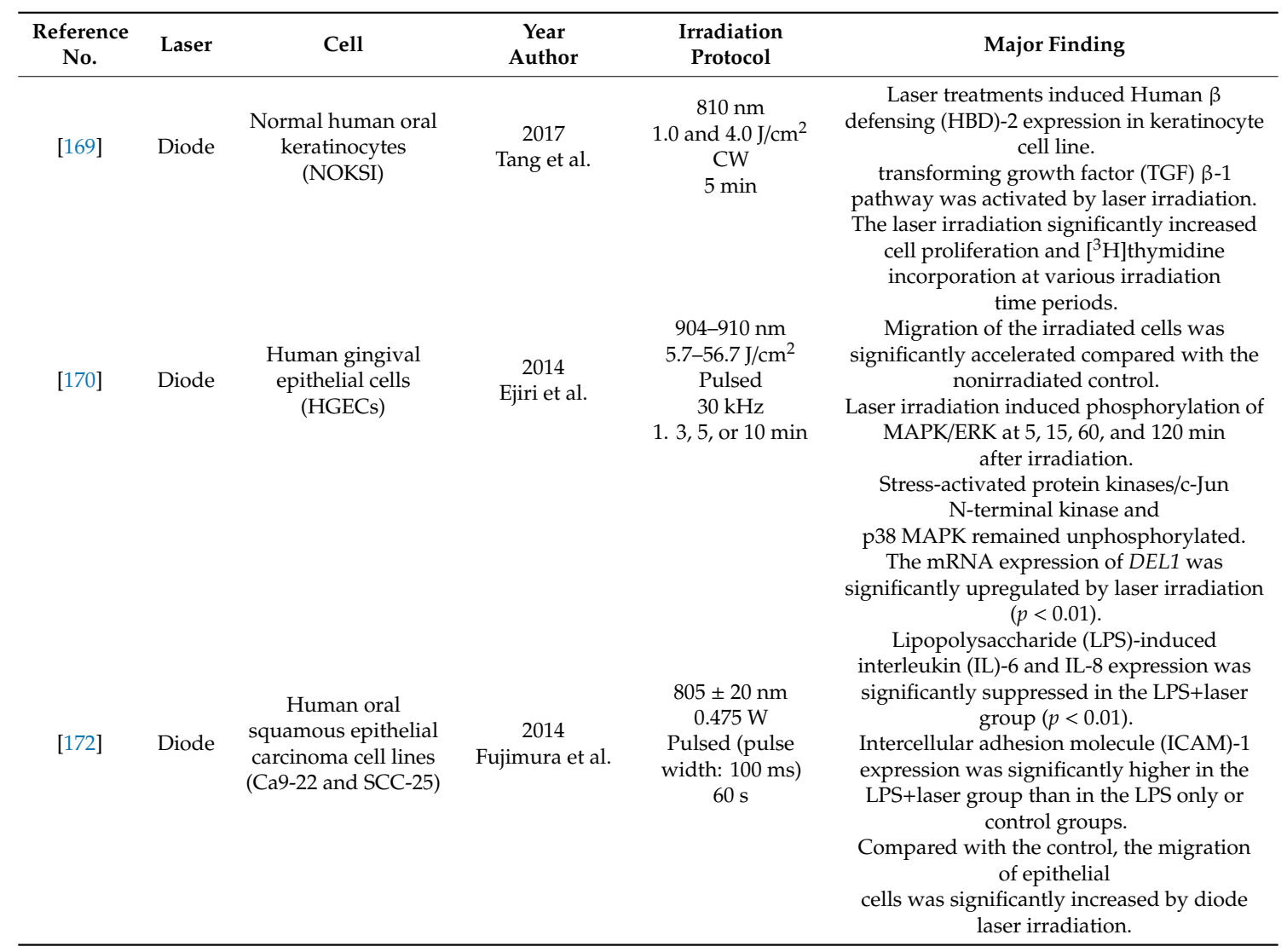

\section{Effects of Laser Irradiation on Osteocytes}

Only a few studies have reported the effects of laser irradiation on osteocytes. Suppression of Sost expression was observed in primary osteocyte-like cells isolated from rat calvaria after $\mathrm{CO}_{2}$ laser irradiation at $0.7-2.8 \mathrm{~J} / \mathrm{cm}^{2}$ without an increase in temperature. The study reported an increase in Dmp1 expression was after $\mathrm{CO}_{2}$ laser irradiation at 1.4-2.8 J/ $\mathrm{cm}^{2}$ [173]. Ohsugi et al. [174] reported that Sost expression in osteogenic cells (osteoblast-like cells isolated from rat calvaria cultured with osteoinduction medium for 21 days) was decreased at $6 \mathrm{~h}$ after Er:YAG laser irradiation $(2940 \mathrm{~nm})$ at energy densities of 1.5 and $3.1 \mathrm{~J} / \mathrm{cm}^{2}$. Following the results obtained by quantitative PCR, sclerostin (coded by Sost) expression in the cultured supernatant was significantly decreased. As sclerostin produced by osteocytes can inhibit osteoblast activity and suppress bone formation, it is thought that Er:YAG laser irradiation may promote bone formation via the suppression of Sost expression. The contents of this section are summarized in Table 7. 
Table 7. Summary of the effects of laser irradiation on osteocytes.

\begin{tabular}{|c|c|c|c|c|c|}
\hline $\begin{array}{c}\text { Reference } \\
\text { No. }\end{array}$ & Laser & Cell & $\begin{array}{c}\text { Year } \\
\text { Author }\end{array}$ & $\begin{array}{l}\text { Irradiation } \\
\text { Protocol }\end{array}$ & Major Finding \\
\hline [173] & $\mathrm{CO}_{2}$ & Osteocyte-like cells & $\begin{array}{c}2013 \\
\text { Yokose, et al. }\end{array}$ & $\begin{array}{c}10,600 \mathrm{~nm} \\
0.71,1.42, \\
\text { and } 2.83 \mathrm{~J} / \mathrm{cm}^{2} \\
\mathrm{CW} \\
10 \mathrm{~s}\end{array}$ & $\begin{array}{l}\text { The mRNA expression of Sost was decreased } \\
\text { and that of Dmp1 was increased in the cells } \\
\text { after dose-dependent laser irradiation. }\end{array}$ \\
\hline [174] & Er:YAG & $\begin{array}{l}\text { Osteogenic cells } \\
\text { (osteoblast-like cells } \\
\text { incubated for } 21 \text { days } \\
\text { by osteoinduction) }\end{array}$ & $\begin{array}{c}2020 \\
\text { Ohsugi, et al. }\end{array}$ & $\begin{array}{c}2940 \mathrm{~nm} \\
1.5 \text { and } 3.1 \mathrm{~J} / \mathrm{cm}^{2} \\
\text { Pulsed } \\
20 \mathrm{~Hz} \\
30 \text { and } 60 \mathrm{~s}\end{array}$ & $\begin{array}{l}\text { The mRNA expression of Sost was decreased } \\
\text { and that of Mef } 2 c \text { was increased in } \\
\text { laser-irradiated cells. }\end{array}$ \\
\hline
\end{tabular}

\section{Effects of Laser Irradiation on Osteoclasts}

Osteoclasts are multinucleated giant cells that have the capacity to resorb mineralized tissues [175]. The development of osteoclasts proceeds within the local microenvironment of the bone.

Only a single report has been published on the effect of laser irradiation on osteoclasts in vitro. Rat osteoclast precursor cells (osteoclast-like cells) purified from rat bone marrow were subjected to laser irradiation with $810 \mathrm{~nm}$ diode and a maximum power output of $50 \mathrm{~mW}$ at exposure times of $1,3,6$, or $10 \mathrm{~min} /$ day, which corresponded to $9.3,28.0,56.0$, or $93.3 \mathrm{~J} / \mathrm{cm}^{2}$, respectively. Laser irradiation at $9.3-56.0 \mathrm{~J} / \mathrm{cm}^{2}$ increased the number of tartrate-resistant, acid phosphatase-positive multinucleate cells. Furthermore, osteoclasts appeared on day 2 in the laser-irradiated groups but not until day 3 in the nonirradiated control groups. Receptor activator of NF-kappaB (RANK) in the laser-irradiated groups showed significantly greater staining compared to the control group on day 2 and 3 by immunohistochemistry, and the mRNA expression of RANK was upregulated, consistent with the immunohistochemistry results. The study suggested that irradiation with an $810 \mathrm{~nm}$ diode laser facilitated the differentiation and activation of osteoclasts via RANK expression [176]. The contents of this section are summarized in Table 8.

Table 8. Summary of the effects of laser irradiation on osteoclasts.

\begin{tabular}{|c|c|c|c|c|c|}
\hline $\begin{array}{l}\text { Reference } \\
\text { No. }\end{array}$ & Laser & Cell & $\begin{array}{l}\text { Year } \\
\text { Author }\end{array}$ & $\begin{array}{c}\text { Irradiation } \\
\text { Protocol }\end{array}$ & Major Finding \\
\hline [176] & Diode & Osteoclasts & $\begin{array}{c}2006 \\
\text { Aihara, et al. }\end{array}$ & $\begin{array}{c}810 \mathrm{~nm} \\
9.33,27.99,55.98, \\
\text { or } 93.30 \mathrm{~J} / \mathrm{cm}^{2} \\
\mathrm{CW} \\
1,3,6, \\
\text { or } 10 \mathrm{~min} / \text { day }\end{array}$ & $\begin{array}{c}\text { Laser irradiated cells showed greater } \\
\text { amounts of staining compared to } \\
\text { non-irradiated cells in } \\
\text { immunohistochemistry for receptor activator } \\
\text { of NF-kappaB (RANK). } \\
\text { The mRNA expression of receptor activator } \\
\text { of RANK was upregulated in low-energy } \\
\text { irradiated cells. }\end{array}$ \\
\hline
\end{tabular}

\section{Effects of Laser Irradiation on Stem Cells}

In multicellular organisms, stem cells are undifferentiated or partially differentiated cells that can differentiate into various types of cells and proliferate indefinitely to produce more numbers of the same stem cells. They are the earliest type of cells in the cell lineage [177]. Mesenchymal stem cells (MSCs) are multipotent cells found in adult tissues. Adult MSCs were isolated from almost every type of connective tissue, such as adipose [178], bone marrow, periodontal ligament [179], and dental pulp tissues [180]. Stem cell therapy is the use of stem cells to treat or prevent diseases. Stem cell therapy is applied to many types of treatments, including regeneration and wound healing [181]. Recently, the PBM effects of laser irradiation on MSCs have attracted much attention. In the next paragraph, we have reviewed the effect of laser irradiation on MSCs.

\subsection{Diode Laser}

Although studies on PBM's effect on MSCs are limited, several studies using diode lasers with different wavelengths have been reported. PBM (using a combination of 630 and $810 \mathrm{~nm}$ lasers) 
stimulated the viability of human adipose-derived stem cells (hASCs) and human bone marrow mesenchymal stem cells (hBM-MSCs). In addition, PBM (irradiation once or twice at $630 \mathrm{~nm}$ and 0.6 and $1.2 \mathrm{~J} / \mathrm{cm}^{2}$ ) increased the viability of hASCs compared to the control and laser-treated hBM-MSCs. Furthermore, PBM (using a combination of 630 and $810 \mathrm{~nm}$ lasers, 3 times irradiation at $2.4 \mathrm{~J} / \mathrm{cm}^{2}$ ) increased hASC viability compared to control and laser-treated hBM-MSCs [182]. Some studies have reported the effect of laser irradiation at around 630 or $810 \mathrm{~nm}$ on MSCs. Diode laser irradiation at $635 \mathrm{~nm}$ in MSCs derived from femurs and tibias in rats caused an increase in the expression levels of v-akt murine thymoma viral oncogene homolog 1 (Akt1), cyclin D1 gene (Ccnd1), phosphatidylinositol 3-kinase, catalytic alpha polypeptide gene (Pik3ca), in addition to a decrease in protein tyrosine phosphatase nonreceptor type 6 (Ptpn6), and serine/threonine kinase $17 \mathrm{~b}(S t k 17 b)$ expression. Microarray analysis was also performed in this study, which revealed that 119 genes were differentially expressed, and various genes involved in cell proliferation, apoptosis, and the cell cycle were affected. The study suggested that the increase in MSC proliferation was mediated through the PI3K/Akt/mTOR/eIF4E pathway [183]. In addition, cytotoxicity evaluated by LDH assay did not show a significant difference between nonirradiated and $635 \mathrm{~nm}$ diode laser-irradiated $\left(0.5-5.0 \mathrm{~J} / \mathrm{cm}^{2}\right)$ MSCs obtained from rat bone marrow. Diode laser irradiation at $0.5 \mathrm{~J} / \mathrm{cm}^{2}$ was found to be an optimal energy density to stimulate the proliferation of bone marrow stromal cells (BMSCs); additionally, irradiation at $5.0 \mathrm{~J} / \mathrm{cm}^{2}$ significantly stimulated the secretion of VEGF and NGF. Furthermore, after 5-aza induction, myogenic differentiation was observed in all the groups, and diode laser irradiation at $5.0 \mathrm{~J} / \mathrm{cm}^{2}$ dramatically facilitated the differentiation [184]. The effect of $635 \mathrm{~nm}$ diode laser irradiation on the osteogenic differentiation of MSCs has also been reported. Laser irradiation $\left(0.4 \mathrm{~J} / \mathrm{cm}^{2}\right)$ on human mesenchymal stromal cells (hMSCs) increased vinculin-rich clusters, osteogenic expression of markers (e.g., Runx-2, alkaline phosphatase, osteopontin), and mineralized bone-like nodule structure deposition as well as induced stress fiber formation and upregulated the expression of the proliferation marker Ki67. The study suggested that $635 \mathrm{~nm}$ diode laser irradiation may be a potentially effective option for promoting/improving bone regeneration [33]. In addition, $635 \mathrm{~nm}$ diode laser irradiation $\left(0.3 \mathrm{~J} / \mathrm{cm}^{2}\right)$ on MSCs derived from the femora and tibia of male C2F1 mice significantly enhanced MSC proliferation, without a change in cell viability. They also found that the increase in proliferation after $635 \mathrm{~nm}$ diode laser irradiation was associated with the upregulation and activation of the Notch-1 pathway and increased membrane conductance through voltage-gated $\mathrm{K}+, \mathrm{BK}$, and Kir channels and T- and L-type $\mathrm{Ca}^{2+}$ channels [185].

Recently, studies on diode laser irradiation at $808 \mathrm{~nm}$ related to MSCs have also been reported. At $0.5-4.0 \mathrm{~J} / \mathrm{cm}^{2}$, irradiation of human gingival mesenchymal stem cells (HGMSCs) promoted their migration but not proliferation. Furthermore, diode laser irradiation could activate mitochondrial ROS, which could elevate the phosphorylation levels of JNK and IKB in HGMSCs, further activating NF- $\mathrm{KB}$ concomitantly with the elevation of the nuclear translocation of p65. Taken together, these results indicate that PBM may promote cell migration via the ROS/JNK/NF-kB pathway [186]. High power $808 \mathrm{~nm}$ diode laser irradiation $\left(64 \mathrm{~J} / \mathrm{cm}^{2}\right)$ enhanced osteogenesis. Laser irradiation of BMSCs from 3-old female BALB/c mice increased the protein expression of Runx2 and Osterix and suppressed PPAR $\gamma$, a pivotal transcription factor in adipogenic differentiation. Positive areas of ALP and Alizarin Red $S$ histochemical staining were significantly increased after laser irradiation [187].

Regarding the $606 \mathrm{~nm}$ diode laser irradiation, irradiation with $1.9 \mathrm{~J} / \mathrm{cm}^{2}$ enhanced the proliferation of BMSCs, although irradiation with $11.7 \mathrm{~J} / \mathrm{cm}^{2}$ suppressed the proliferation. The cytotoxic effect of $50 \mu \mathrm{g} / \mathrm{mL}$ carboplatin was eliminated, and the inhibitory effect of $0.1 \mu \mathrm{g} / \mathrm{mL}$ vincristine was attenuated by laser irradiation at $1.9 \mathrm{~J} / \mathrm{cm}^{2}$ [188]. In addition, $660 \mathrm{~nm}$ diode laser irradiation $\left(5 \mathrm{~J} / \mathrm{cm}^{2}\right)$ on stem cells from human exfoliated deciduous teeth (SHEDs) increased cell proliferation and expression of mesenchymal stem cell markers, including OCT4, Nestin, and CD90 [189]. However, another study showed that human dental pulp stem cells (hDPSCs) irradiated at $660 \mathrm{~nm}$ and $5 \mathrm{~J} / \mathrm{cm}^{2}$ showed signs of apoptosis and necrosis as observed by transmission electron microscopy (TEM). Diode laser irradiation at $3 \mathrm{~J} / \mathrm{cm}^{2}$ increased fibronectin production in hDPSCs [190]. The effects of $660 \mathrm{~nm}$ diode laser 
irradiation $\left(1.6 \mathrm{~J} / \mathrm{cm}^{2}\right)$ were also evaluated in hDPSCs. Gene expression of brain-derived neurotrophic factor $(B D N F)$, glial cell line-derived neurotrophic factor (GNDF), matrix-associated protein $2(M A P 2)$, nuclear receptor-related 1 protein (NURR1), and dopamine transporter (DAT) were increased, especially in the first 7 days of dopaminergic induction. However, the hDPSCs were not able to differentiate into functional dopaminergic neurons either in nonirradiated control or laser-irradiated groups [191].

\subsection{Nd:YAG Laser}

There are some reports on the effects of Nd:YAG laser irradiation on MSCs. Nd:YAG laser irradiation ( 2 and $\left.4 \mathrm{~J} / \mathrm{cm}^{2}\right)$ on hBMSCs promoted proliferation and osteogenesis, although irradiation at an energy density of $16 \mathrm{~J} / \mathrm{cm}^{2}$ significantly suppressed the proliferation and osteogenesis of hBMSCs [192]. In addition, Nd:YAG laser irradiation at $9.8 \mathrm{~J} / \mathrm{cm}^{2}$ on MSCs obtained from horses did not show a difference in viability between irradiated and control MSCs. However, laser-irradiated MSCs exhibited slightly lower proliferation and significantly increased expression of IL-10 and VEGF compared to nonirradiated control MSCs [193]. Frequency-doubled Nd:YAG laser irradiation (532 nm) of human adipose tissue-derived stem cells (hADSCs) was performed at densities of $5-45 \mathrm{~J} / \mathrm{cm}^{2}$ for 30-300 s. Mitochondrial activity of hADSCs was evaluated by autofluorescence emission at wavelengths associated with nicotinamide adenine dinucleotide (NADH) and flavoproteins. Laser irradiation at $5-9.2 \mathrm{~J} / \mathrm{cm}^{2}$ significantly increased the proliferation of hADSCs, which was attributed to an increase in mitochondrial activity, although hADSCs irradiated at 28 and $45 \mathrm{~J} / \mathrm{cm}^{2}$ showed a significant decrease in proliferation and autofluorescence [194].

\section{3. $\mathrm{CO}_{2}$ Laser}

We found only one report that mentioned the effect of $\mathrm{CO}_{2}$ laser irradiation on MSCs in an in vitro study. $\mathrm{CO}_{2}$ laser irradiation ( $9 \mathrm{~W}$, exposure time $4 \mathrm{~ms} / \mathrm{shot}$ and a medium pattern of the spots) on hADSCs increased their proliferation when cultured under nutrient-deprived conditions $(0.5 \%$ FBS $)$ and reduced cell proliferation in a medium supplemented with $10 \% \mathrm{FBS} . \mathrm{CO}_{2}$ laser irradiation caused a transient increase in mitochondrial ROS and the capacity to restore $\Delta \psi \mathrm{m}$ after rotenone-induced depolarization, and increased the secretion of MMP-2 in conditioned media comprising MMP-9, VEGF, and adiponectin, which have the capacity to support the angiogenesis of endothelial progenitor cells. The study concluded that $\mathrm{CO}_{2}$ laser irradiation on ADSCs might activate the redox pathways that increase cell proliferation and enhance the secretion of angiogenic molecules [195].

\subsection{Summary}

The contents of this section are summarized in Table 9. Reports on the effects of laser irradiation on MSCs are limited. However, some studies have shown that laser irradiation, especially low-power irradiation, causes cell proliferation and favorable gene expression changes in MSCs. MSCs are already clinically applied for periodontal regeneration. MSC sheets transplanted to root surfaces can induce regeneration of periodontal tissue [196]. Although further research is required to clarify the effects of laser irradiation on MSCs, laser irradiation may enhance MSCs regenerative capabilities in periodontal tissues. 
Table 9. Summary of the effects of laser irradiation on mesenchymal stem cells.

\begin{tabular}{|c|c|c|c|c|c|}
\hline $\begin{array}{l}\text { Reference } \\
\text { No. }\end{array}$ & Laser & Cell & $\begin{array}{c}\text { Year } \\
\text { Author }\end{array}$ & $\begin{array}{l}\text { Irradiation } \\
\text { Protocol }\end{array}$ & Major Finding \\
\hline [182] & Diode & $\begin{array}{c}\text { Human bone } \\
\text { marrow-derived } \\
\text { mesenchymal stem } \\
\text { cells (hBM-MSCs) } \\
\text { human } \\
\text { adipose-derived } \\
\text { stem cells (hASCs) }\end{array}$ & $\begin{array}{c}2019 \\
\text { Zare et al. }\end{array}$ & $\begin{array}{c}630 \text { and } 810 \mathrm{~nm} \\
0.6,1.2 \\
\text { or } 2.4 \mathrm{~J} / \mathrm{cm}^{2} \\
10 \mathrm{~s}\end{array}$ & $\begin{array}{c}\text { Laser irradiation combined } 630 \text { and } 810 \mathrm{~nm} \\
\text { significantly stimulated cell viability, } \\
\text { and decreased apoptosis in hBM-MSCs } \\
\text { and hASCs. }\end{array}$ \\
\hline [183] & Diode & $\begin{array}{l}\text { Mesenchymal stem } \\
\text { cells (MSCs) isolated } \\
\text { from femurs and } \\
\text { tibias in rat }\end{array}$ & $\begin{array}{c}2012 \\
\text { Wu et al. }\end{array}$ & $\begin{array}{c}635 \mathrm{~nm} \\
0.5 \mathrm{~J} / \mathrm{cm}^{2} \\
75 \mathrm{~s}\end{array}$ & $\begin{array}{c}\text { Microarray analysis revealed } 119 \\
\text { differentially expressed genes after } \\
\text { laser irradiation. } \\
\text { mRNA expression of } A k t 1, C c n d 1 \text {, and } P i k 3 c a \\
\text { were upregulated and Ptpn6 and } S k t 17 b \\
\text { expression were downregulated. }\end{array}$ \\
\hline [184] & Diode & $\begin{array}{l}\text { Mesenchymal stem } \\
\text { cells (MSCs) isolated } \\
\text { from femurs and } \\
\text { tibias in rat }\end{array}$ & $\begin{array}{l}2008 \\
\text { Hou et al. }\end{array}$ & $\begin{array}{c}635 \mathrm{~nm} \\
0.5-5.0 \mathrm{~J} / \mathrm{cm}^{2} \\
\mathrm{CW} \\
75-750 \mathrm{~s}\end{array}$ & $\begin{array}{l}\text { Laser irradiation at } 0.5 \mathrm{~J} / \mathrm{cm}^{2} \text { stimulated } \\
\text { MSCs proliferation. } \\
\text { Laser irradiation at } 5.0 \mathrm{~J} / \mathrm{cm}^{2} \text { increased VEGF } \\
\text { and nerve growth factor secretion and } \\
\text { dramatically facilitated the differentiation. }\end{array}$ \\
\hline [33] & Diode & $\begin{array}{l}\text { Human } \\
\text { mesenchymal } \\
\text { stromal cells } \\
\text { (hMSCs) }\end{array}$ & $\begin{array}{c}2018 \\
\text { Tani et al. }\end{array}$ & $\begin{array}{c}635 \text {, or } 808 \mathrm{~nm} \\
0.378 \mathrm{~J} / \mathrm{cm}^{2} \\
\mathrm{CW} \\
30 \mathrm{~s}\end{array}$ & $\begin{array}{l}\text { Irradiation at } 635 \mathrm{~nm} \text { increased Runx2 and } \\
\text { Alpl mRNA expression, and expression of } \\
\text { osteopontin and Ki67. }\end{array}$ \\
\hline [185] & Diode & $\begin{array}{l}\text { Mesenchymal stem } \\
\text { cells (MSCs) isolated } \\
\text { from femurs and } \\
\text { tibias in male } \\
\text { C2F1 mice }\end{array}$ & $\begin{array}{c}2013 \\
\text { Giannelli et al. }\end{array}$ & $\begin{array}{c}635 \mathrm{~nm} \\
0.3 \mathrm{~J} / \mathrm{cm}^{2} \\
\mathrm{CW} \\
10,26 \mathrm{~s}\end{array}$ & $\begin{array}{l}\text { Cell proliferation was increased without } \\
\text { change of cell viability. } \\
\text { Increase in cell proliferation was associated } \\
\text { with the upregulation and activation of } \\
\text { Notch-1 pathway. }\end{array}$ \\
\hline [186] & Diode & $\begin{array}{l}\text { Human gingival } \\
\text { mesenchymal stem } \\
\text { cells (HGMSCs) }\end{array}$ & $\begin{array}{c}2020 \\
\text { Feng et al. }\end{array}$ & $\begin{array}{c}808 \mathrm{~nm} \\
0.5-4.0 \mathrm{~J} / \mathrm{cm}^{2} \\
\mathrm{CW}\end{array}$ & $\begin{array}{l}\text { Laser irradiation promoted cell migration but } \\
\text { not cell proliferation. } \\
\text { Laser irradiation at } 1.0 \mathrm{~J} / \mathrm{cm}^{2} \text { activated } \\
\text { mitochondrial ROS after } 2 \mathrm{~h} \text {. }\end{array}$ \\
\hline [187] & Diode & $\begin{array}{l}\text { Bone marrow } \\
\text { stromal cells (MSCs) } \\
\text { isolated from 3-old } \\
\text { female BALB-c mice }\end{array}$ & $\begin{array}{c}2018 \\
\text { Amaroli et al. }\end{array}$ & $\begin{array}{l}808 \mathrm{~nm} \\
64 \mathrm{~J} / \mathrm{cm}^{2} \\
\mathrm{CW} \\
60 \mathrm{~s}\end{array}$ & $\begin{array}{c}\text { Laser irradiation increased Runx2 and } \\
\text { Osterix and decreased Ppary } \\
\text { protein expression. } \\
\text { Positive areas of alkaline phosphatase and } \\
\text { Arizarin Red S staining were significantly } \\
\text { increased after irradiation. }\end{array}$ \\
\hline [188] & Diode & $\begin{array}{l}\text { Bone marrow stem } \\
\text { cells (MSCs) isolated } \\
\text { from young adult } \\
\text { C57Bl/6 mice }\end{array}$ & $\begin{array}{l}2009 \\
\text { Horvat-Karajz et al. }\end{array}$ & $\begin{array}{l}660 \mathrm{~nm} \\
1.9-11.7 \mathrm{~J} / \mathrm{cm}^{2} \\
\mathrm{CW} \\
25-75 \mathrm{~s}\end{array}$ & $\begin{array}{c}\text { Laser irradiation at } 1.9 \mathrm{~J} / \mathrm{cm}^{2} \text { enhanced cell } \\
\text { proliferation, although irradiation at } \\
11.7 \mathrm{~J} / \mathrm{cm}^{2} \text { suppressed cell proliferation. }\end{array}$ \\
\hline [189] & Diode & $\begin{array}{l}\text { Stem cells from } \\
\text { human exfoliated } \\
\text { deciduous teeth } \\
\text { (SHEDs) }\end{array}$ & $\begin{array}{l}2019 \\
\text { Ferreira et al. }\end{array}$ & $\begin{array}{c}660 \mathrm{~nm} \\
1-20 \mathrm{~J} / \mathrm{cm}^{2} \\
\mathrm{CW} \\
1-28 \mathrm{~s}\end{array}$ & $\begin{array}{c}\text { Laser irradiation at } 5 \mathrm{~J} / \mathrm{cm}^{2} \text { enhanced } \\
\text { cell proliferation. } \\
\text { mRNA expression of OCT4, NES, and CD90 } \\
\text { was increased, although that of CD105 was } \\
\text { decreased after irradiation at } 5 \mathrm{~J} / \mathrm{cm}^{2} \text {. }\end{array}$ \\
\hline [190] & Diode & $\begin{array}{l}\text { Human dental pulp } \\
\text { stem cells (hDPSCs) }\end{array}$ & $\begin{array}{l}2019 \\
\text { Garrido et al. }\end{array}$ & $\begin{array}{c}660 \mathrm{~nm} \\
3 \text { and } 5 \mathrm{~J} / \mathrm{cm}^{2} \\
\mathrm{CW} \\
4 \text { and } 7 \mathrm{~s}\end{array}$ & $\begin{array}{c}\text { Laser irradiation at } 3 \mathrm{~J} / \mathrm{cm}^{2} \text { increased } \\
\text { fibronectin expression. } \\
\text { hDPSCs irradiated at } 5 \mathrm{~J} / \mathrm{cm}^{2} \text { showed sign of } \\
\text { apoptosis and necrosis. }\end{array}$ \\
\hline [191] & Diode & $\begin{array}{l}\text { Human dental pulp } \\
\text { stem cells (hDPSCs) }\end{array}$ & $\begin{array}{c}2020 \\
\text { Yurtsever et al. }\end{array}$ & $\begin{array}{c}660 \mathrm{~nm} \\
0.6, \text { or } 1.6 \mathrm{~J} / \mathrm{cm}^{2} \\
240 \text { or } 600 \mathrm{~s}\end{array}$ & $\begin{array}{c}\text { Laser irradiation at } 1.6 \mathrm{~J} / \mathrm{cm}^{2} \text { increased } \\
\text { mRNA expression of brain-derived } \\
\text { neurotrophic factor }(B D N F) \text {, glial cell } \\
\text { line-derived neurotrophic factor }(G D N F), \\
\text { matrix-associated protein } 2(M A P 2), \text { nuclear } \\
\text { receptor-related } 1 \text { protein }(N U R R 1), \\
\text { and dopamine transporter }(D A T) \text { in hDPSCs. }\end{array}$ \\
\hline [192] & Nd:YAG & $\begin{array}{l}\text { Human bone } \\
\text { marrow } \\
\text { mesenchymal stem } \\
\text { cells (BMSCs) }\end{array}$ & $\begin{array}{c}2019 \\
\text { Wang et al. }\end{array}$ & $\begin{array}{c}1064 \mathrm{~nm} \\
2,4,8, \text { or } 16 \mathrm{~J} / \mathrm{cm}^{2} \\
20 \mathrm{~s}\end{array}$ & $\begin{array}{l}\text { Laser irradiation at } 2 \text { and } 4 \mathrm{~J} / \mathrm{cm}^{2} \text { promoted } \\
\text { proliferation and osteogenesis in BMSCs. } \\
\text { Laser irradiation at } 16 \mathrm{~J} / \mathrm{cm}^{2} \text { suppressed } \\
\text { proliferation and osteogenesis in BMSCs. } \\
\text { Laser-irradiated BMSCs did not show a }\end{array}$ \\
\hline [193] & Nd:YAG & $\begin{array}{l}\text { Horse bone marrow } \\
\text { mesenchymal stem } \\
\text { cells (BMSCs) }\end{array}$ & $\begin{array}{c}2018 \\
\text { Peat et al. }\end{array}$ & $\begin{array}{l}1064 \mathrm{~nm} \\
9.77 \mathrm{~J} / \mathrm{cm}^{2} \\
\text { Pulsed } \\
10 \mathrm{~Hz} \\
10 \mathrm{~s}\end{array}$ & $\begin{array}{c}\text { difference in viability. } \\
\text { Laser-irradiated BMSCs exhibited slightly } \\
\text { lower proliferation. } \\
\text { Interleukin }(I L) 10 \text { and } V E G F \text { mRNA } \\
\text { expression was increased after } \\
\text { laser irradiation. }\end{array}$ \\
\hline
\end{tabular}


Table 9. Cont.

\begin{tabular}{|c|c|c|c|c|c|}
\hline $\begin{array}{l}\text { Reference } \\
\text { No. }\end{array}$ & Laser & Cell & $\begin{array}{c}\text { Year } \\
\text { Author }\end{array}$ & $\begin{array}{c}\text { Irradiation } \\
\text { Protocol }\end{array}$ & Major Finding \\
\hline [194] & Nd:YAG & $\begin{array}{c}\text { Human } \\
\text { adipose-derived } \\
\text { stem cells (hADSCs) }\end{array}$ & $\begin{array}{c}2012 \\
\text { Anwer et al. }\end{array}$ & $\begin{array}{c}532 \mathrm{~nm} \\
5-45 \mathrm{~J} / \mathrm{cm}^{2} \\
\mathrm{CW} \\
30-300 \mathrm{~s}\end{array}$ & $\begin{array}{l}\text { Laser irradiation at } 5-9.2 \mathrm{~J} / \mathrm{cm}^{2} \text { increased cell } \\
\text { proliferation by increasing mitochondrial } \\
\text { activity in hADSCs. } \\
\text { Laser irradiation at } 28 \text { and } 45 \mathrm{~J} / \mathrm{cm}^{2} \text { decreased } \\
\text { cell proliferation in hADSCs. }\end{array}$ \\
\hline [195] & $\mathrm{CO}_{2}$ & $\begin{array}{c}\text { Human } \\
\text { adipose-derived } \\
\text { stem cells (hADSCs) }\end{array}$ & $\begin{array}{l}2017 \\
\text { Constantin et al. }\end{array}$ & $\begin{array}{l}10,600 \mathrm{~nm} \\
\text { 5, 9, or } 10 \mathrm{~W} \\
\text { Pulsed } \\
\text { 2-7 ms/shot }\end{array}$ & $\begin{array}{l}\text { Laser irradiation (output power } 9 \mathrm{~W} \text {, } \\
\text { exposure time } 4 \text { ms/shot) increased } \\
\text { proliferation, mitochondrial ROS, the } \\
\text { capacity to restore } \Delta \psi \mathrm{m} \text { after } \\
\text { rotenone-induced depolarization and the } \\
\text { secretion of matrix } \\
\text { metalloproteinase (MMP)-2. }\end{array}$ \\
\hline
\end{tabular}

\section{Conclusions}

This review summarizes the effects of laser irradiation on cells related to periodontal tissues (Figure 1) and clearly shows that laser irradiation can have many positive effects on various cell types in periodontal tissues. Numerous studies have reported that laser irradiation enhances cell proliferation, migration, viability, calcification, gene expression, and protein expression. Additionally, the favorable effects on cells vary depending on the fluences and type of lasers. Irradiation using diodes or Nd:YAG lasers is clinically feasible and can be applied in association with any periodontal procedure, since it reaches deep tissues due to its deeply penetrating wavelength. By contrast, Er:YAG and $\mathrm{CO}_{2}$ lasers, which are only superficially absorbed, are only effective on epithelial cells and connective tissue surfaces, during nonsurgical periodontal treatments, or exposed bone and connective tissues, during periodontal surgeries. Although the purposes of periodontal treatment include anti-inflammation, tissue repair, and tissue regeneration, a single laser irradiation under a single specific irradiation condition cannot achieve all desired positive effects. Furthermore, a certain irradiation condition might have negative effects on some cells in periodontal tissues, since appropriate irradiation conditions vary with cell type. When applying a laser to regenerate periodontal tissues in the clinic, it is necessary to consider which cells need to be targeted and activated and then select the suitable laser type and energy fluence to match the cell type. However, there is still insufficient basic research on the PBM of lasers from this review. Because the type of lasers, irradiation time, distance, and fluence are quite varied, it is difficult to critically determine the optimal criteria for laser usage. From this review, we realize the promising PBM effects of lasers in periodontal therapy, and we can gain insights regarding the appropriate fluences to be utilized in laser applications to osteoblasts, fibroblasts, and MSCs. We will continue to research lasers for periodontal phototherapy, including regeneration of periodontal tissues in the future. 


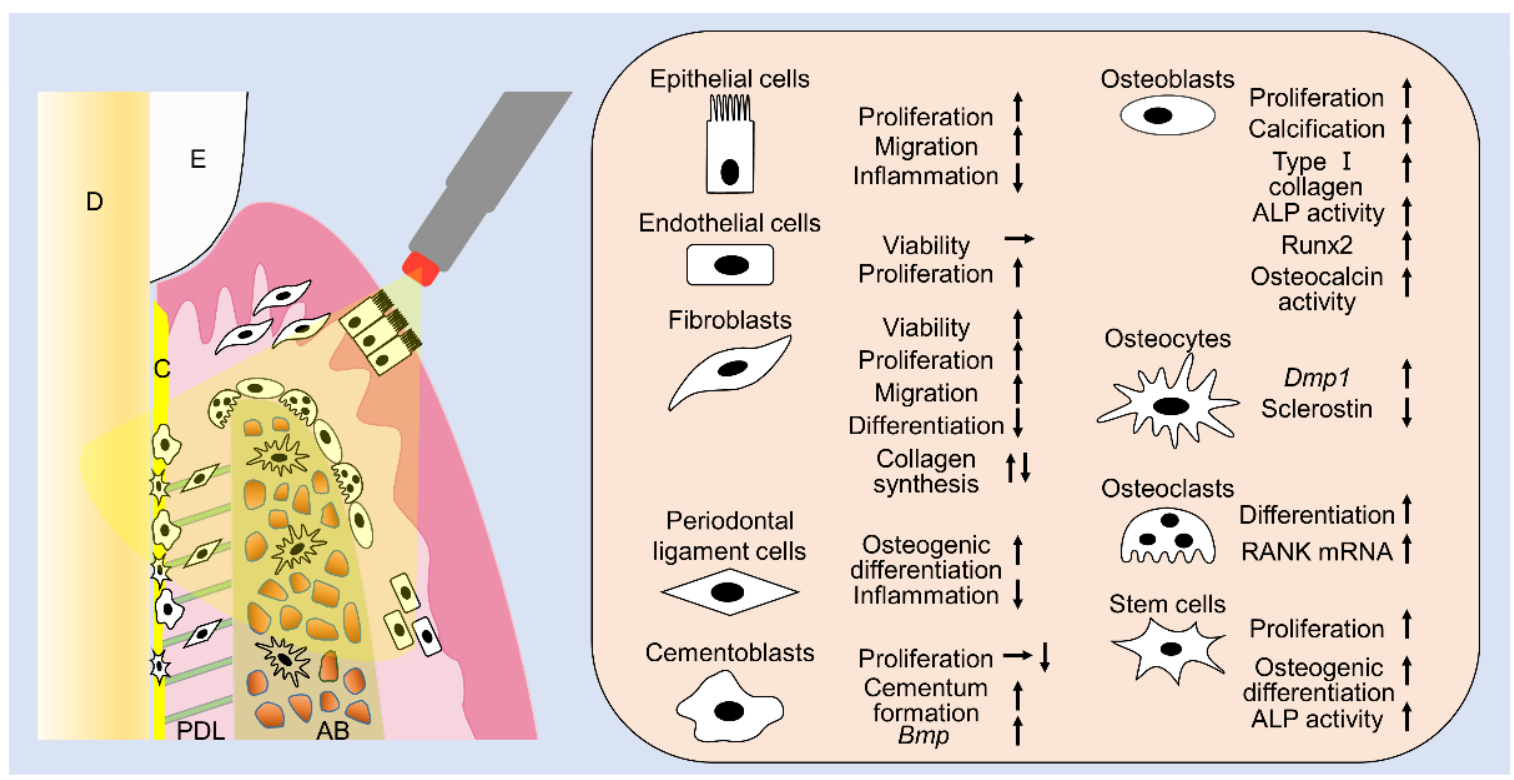

Figure 1. The summary of this review. Laser irradiation has various effects on cells related to periodontal tissues. E: enamel, D: dentin, PDL: periodontal ligament, AB: alveolar bone.

Author Contributions: Literature collection, Y.O., H.N., T.S., M.H., and S.K.; writing, Y.O., H.N., T.S., M.H., S.K., and A.A.; revision, S.K. and T.I. All authors have read and agreed to the published version of the manuscript.

Funding: This research was supported by JSPS KAKENHI, Grant Number JP20K21670, to T.I. and JP20K18501, to Y.O.

Conflicts of Interest: The authors declare no conflict of interest.

\section{References}

1. Lang, N.P.; Lindhe, J. Clinical Periodontology and Implant Dentistry; John Wiley \& Sons: Hoboken, NJ, USA, 2015; Volume 2.

2. Kinane, D.F.; Stathopoulou, P.G.; Papapanou, P.N. Periodontal diseases. Nat. Rev. Dis. Primers 2017, 3, 17038. [CrossRef] [PubMed]

3. Suvan, J.; Leira, Y.; Moreno Sancho, F.M.; Graziani, F.; Derks, J.; Tomasi, C. Subgingival instrumentation for treatment of periodontitis. A systematic review. J. Clin. Periodontol. 2020, 47 (Suppl. 22), 155-175. [CrossRef] [PubMed]

4. Aoki, A.; Mizutani, K.; Schwarz, F.; Sculean, A.; Yukna, R.A.; Takasaki, A.A.; Romanos, G.E.; Taniguchi, Y.; Sasaki, K.M.; Zeredo, J.L.; et al. Periodontal and peri-implant wound healing following laser therapy. Periodontoloy 2000 2015, 68, 217-269. [CrossRef] [PubMed]

5. Mizutani, K.; Aoki, A.; Coluzzi, D.; Yukna, R.; Wang, C.Y.; Pavlic, V.; Izumi, Y. Lasers in minimally invasive periodontal and peri-implant therapy. Periodontoloy 2000 2016, 71, 185-212. [CrossRef] [PubMed]

6. Gholami, L.; Asefi, S.; Hooshyarfard, A.; Sculean, A.; Romanos, G.E.; Aoki, A.; Fekrazad, R. Photobiomodulation in Periodontology and Implant Dentistry: Part 1. Photobiomodul. Photomed. Laser Surg. 2019, 37, 739-765. [CrossRef]

7. Ruh, A.C.; Frigo, L.; Cavalcanti, M.; Svidnicki, P.; Vicari, V.N.; Lopes-Martins, R.A.B.; Leal Junior, E.C.P.; De Isla, N.; Diomede, F.; Trubiani, O.; et al. Laser photobiomodulation in pressure ulcer healing of human diabetic patients: Gene expression analysis of inflammatory biochemical markers. Lasers Med. Sci. 2018, 33, 165-171. [CrossRef]

8. Cavalcanti, M.F.; Silva, U.H.; Leal-Junior, E.C.; Lopes-Martins, R.A.; Marcos, R.L.; Pallotta, R.C.; Diomede, F.; Trubiani, O.; De Isla, N.; Frigo, L. Comparative Study of the Physiotherapeutic and Drug Protocol and Low-Level Laser Irradiation in the Treatment of Pain Associated with Temporomandibular Dysfunction. Photomed. Laser Surg. 2016, 34, 652-656. [CrossRef] 
9. Heiskanen, V.; Hamblin, M.R. Photobiomodulation: Lasers vs. light emitting diodes? Photochem. Photobiol. Sci. 2018, 17, 1003-1017. [CrossRef]

10. Anders, J.J.; Lanzafame, R.J.; Arany, P.R. Low-level light/laser therapy versus photobiomodulation therapy. Photomed. Laser Surg. 2015, 33, 183-184. [CrossRef]

11. Hale, G.M.; Querry, M.R. Optical constants of water in the 200-nm to 200- $\mu$ m wavelength region. Appl. Opt. 1973, 12, 555-563. [CrossRef]

12. Niemz, M.H. Laser-Tissue Interaction. In Fundamentals and Applications; Springer: Berlin, Germany, 1996.

13. Aoki, A.; Sasaki, K.; Watanabe, H.; Ishikawa, I. Lasers in non-surgical periodontal therapy. Periodontology 2000 2004, 36, 59-97. [CrossRef] [PubMed]

14. Hadjidakis, D.J.; Androulakis, I.I. Bone remodeling. Ann. N. Y. Acad. Sci. 2006, 1092, $385-396$. [CrossRef] [PubMed]

15. Yamamoto, M.; Tamura, K.; Hiratsuka, K.; Abiko, Y. Stimulation of MCM3 gene expression in osteoblast by low level laser irradiation. Lasers Med. Sci. 2001, 16, 213-217. [CrossRef] [PubMed]

16. Hamajima, S.; Hiratsuka, K.; Kiyama-Kishikawa, M.; Tagawa, T.; Kawahara, M.; Ohta, M.; Sasahara, H.; Abiko, Y. Effect of low-level laser irradiation on osteoglycin gene expression in osteoblasts. Lasers Med. Sci. 2003, 18, 78-82. [CrossRef] [PubMed]

17. Renno, A.C.; McDonnell, P.A.; Parizotto, N.A.; Laakso, E.L. The effects of laser irradiation on osteoblast and osteosarcoma cell proliferation and differentiation in vitro. Photomed. Laser Surg. 2007, 25, 275-280. [CrossRef]

18. Fujimoto, K.; Kiyosaki, T.; Mitsui, N.; Mayahara, K.; Omasa, S.; Suzuki, N.; Shimizu, N. Low-intensity laser irradiation stimulates mineralization via increased BMPs in MC3T3-E1 cells. Lasers Surg. Med. 2010, 42, 519-526. [CrossRef]

19. Kanenari, M.; Zhao, J.; Abiko, Y. Enhancement of microtubule-associated protein-1 Alpha gene expression in osteoblasts by low level laser irradiation. Laser 2011, 20, 47-51. [CrossRef]

20. Migliario, M.; Pittarella, P.; Fanuli, M.; Rizzi, M.; Reno, F. Laser-induced osteoblast proliferation is mediated by ROS production. Lasers Med. Sci. 2014, 29, 1463-1467. [CrossRef]

21. Pagin, M.T.; de Oliveira, F.A.; Oliveira, R.C.; Sant'Ana, A.C.; de Rezende, M.L.; Greghi, S.L.; Damante, C.A. Laser and light-emitting diode effects on pre-osteoblast growth and differentiation. Lasers Med. Sci. 2014, 29, 55-59. [CrossRef]

22. Oliveira, F.A.; Matos, A.A.; Matsuda, S.S.; Buzalaf, M.A.; Bagnato, V.S.; Machado, M.A.; Damante, C.A.; Oliveira, R.C.; Peres-Buzalaf, C. Low level laser therapy modulates viability, alkaline phosphatase and matrix metalloproteinase-2 activities of osteoblasts. J. Photochem. Photobiol. B 2017, 169, 35-40. [CrossRef]

23. Son, J.H.; Park, B.S.; Kim, I.R.; Sung, I.Y.; Cho, Y.C.; Kim, J.S.; Kim, Y.D. A novel combination treatment to stimulate bone healing and regeneration under hypoxic conditions: Photobiomodulation and melatonin. Lasers Med. Sci. 2017, 32, 533-541. [CrossRef] [PubMed]

24. Li, Q.; Chen, Y.; Dong, S.; Liu, S.; Zhang, X.; Si, X.; Zhou, Y. Laser irradiation promotes the proliferation of mouse pre-osteoblast cell line MC3T3-E1 through hedgehog signaling pathway. Lasers Med. Sci. 2017, 32, 1489-1496. [CrossRef] [PubMed]

25. Kunimatsu, R.; Gunji, H.; Tsuka, Y.; Yoshimi, Y.; Awada, T.; Sumi, K.; Nakajima, K.; Kimura, A.; Hiraki, T.; Abe, T.; et al. Effects of high-frequency near-infrared diode laser irradiation on the proliferation and migration of mouse calvarial osteoblasts. Lasers Med. Sci. 2018, 33, 959-966. [CrossRef] [PubMed]

26. Mikami, R.; Mizutani, K.; Aoki, A.; Tamura, Y.; Aoki, K.; Izumi, Y. Low-level ultrahigh-frequency and ultrashort-pulse blue laser irradiation enhances osteoblast extracellular calcification by upregulating proliferation and differentiation via transient receptor potential vanilloid 1. Lasers Surg. Med. 2018, 50, 340-352. [CrossRef]

27. Coombe, A.R.; Ho, C.T.; Darendeliler, M.A.; Hunter, N.; Philips, J.R.; Chapple, C.C.; Yum, L.W. The effects of low level laser irradiation on osteoblastic cells. Clin. Orthod. Res. 2001, 4, 3-14. [CrossRef]

28. Bayram, H.; Kenar, H.; Tasar, F.; Hasirci, V. Effect of low level laser therapy and zoledronate on the viability and ALP activity of Saos-2 cells. Int. J. Oral. Maxillofac. Surg. 2013, 42, 140-146. [CrossRef]

29. Bloise, N.; Ceccarelli, G.; Minzioni, P.; Vercellino, M.; Benedetti, L.; De Angelis, M.G.; Imbriani, M.; Visai, L. Investigation of low-level laser therapy potentiality on proliferation and differentiation of human osteoblast-like cells in the absence/presence of osteogenic factors. J. Biomed. Opt. 2013, 18, 128006. [CrossRef]

30. Incerti Parenti, S.; Checchi, L.; Fini, M.; Tschon, M. Different doses of low-level laser irradiation modulate the in vitro response of osteoblast-like cells. J. Biomed. Opt. 2014, 19, 108002. [CrossRef] 
31. Tschon, M.; Incerti-Parenti, S.; Cepollaro, S.; Checchi, L.; Fini, M. Photobiomodulation with low-level diode laser promotes osteoblast migration in an in vitro micro wound model. J. Biomed. Opt. 2015, 20, 78002. [CrossRef]

32. Heymann, P.G.; Ziebart, T.; Kammerer, P.W.; Mandic, R.; Saydali, A.; Braun, A.; Neff, A.; Draenert, G.F. The enhancing effect of a laser photochemotherapy with cisplatin or zolendronic acid in primary human osteoblasts and osteosarcoma cells in vitro. J. Oral. Pathol. Med. 2016, 45, 803-809. [CrossRef]

33. Tani, A.; Chellini, F.; Giannelli, M.; Nosi, D.; Zecchi-Orlandini, S.; Sassoli, C. Red (635 nm), Near-Infrared $(808 \mathrm{~nm})$ and Violet-Blue $(405 \mathrm{~nm})$ Photobiomodulation Potentiality on Human Osteoblasts and Mesenchymal Stromal Cells: A Morphological and Molecular in vitro Study. Int. J. Mol. Sci. 2018, 19, 1946. [CrossRef] [PubMed]

34. Stein, E.; Koehn, J.; Sutter, W.; Wendtlandt, G.; Wanschitz, F.; Thurnher, D.; Baghestanian, M.; Turhani, D. Initial effects of low-level laser therapy on growth and differentiation of human osteoblast-like cells. Wien Klin Wochenschr 2008, 120, 112-117. [CrossRef] [PubMed]

35. Saracino, S.; Mozzati, M.; Martinasso, G.; Pol, R.; Canuto, R.A.; Muzio, G. Superpulsed laser irradiation increases osteoblast activity via modulation of bone morphogenetic factors. Lasers Surg. Med. 2009, 41, 298-304. [CrossRef] [PubMed]

36. Huang, T.H.; Lu, Y.C.; Kao, C.T. Low-level diode laser therapy reduces lipopolysaccharide (LPS)-induced bone cell inflammation. Lasers Med. Sci. 2012, 27, 621-627. [CrossRef] [PubMed]

37. Huertas, R.M.; Luna-Bertos, E.D.; Ramos-Torrecillas, J.; Leyva, F.M.; Ruiz, C.; Garcia-Martinez, O. Effect and clinical implications of the low-energy diode laser on bone cell proliferation. Biol. Res. Nurs. 2014, 16, 191-196. [CrossRef] [PubMed]

38. Incerti Parenti, S.; Panseri, S.; Gracco, A.; Sandri, M.; Tampieri, A.; Alessandri Bonetti, G. Effect of low-level laser irradiation on osteoblast-like cells cultured on porous hydroxyapatite scaffolds. Ann. Ist. Super Sanita 2013, 49, 255-260. [PubMed]

39. Medina-Huertas, R.; Manzano-Moreno, F.J.; De Luna-Bertos, E.; Ramos-Torrecillas, J.; Garcia-Martinez, O.; Ruiz, C. The effects of low-level diode laser irradiation on differentiation, antigenic profile, and phagocytic capacity of osteoblast-like cells (MG-63). Lasers Med. Sci. 2014, 29, 1479-1484. [CrossRef] [PubMed]

40. Manzano-Moreno, F.J.; Medina-Huertas, R.; Ramos-Torrecillas, J.; Garcia-Martinez, O.; Ruiz, C. The effect of low-level diode laser therapy on early differentiation of osteoblast via BMP-2/TGF-beta1 and its receptors. J. Craniomaxillofac. Surg. 2015, 43, 1926-1932. [CrossRef]

41. Pyo, S.J.; Song, W.W.; Kim, I.R.; Park, B.S.; Kim, C.H.; Shin, S.H.; Chung, I.K.; Kim, Y.D. Low-level laser therapy induces the expressions of BMP-2, osteocalcin, and TGF-beta1 in hypoxic-cultured human osteoblasts. Lasers Med. Sci. 2013, 28, 543-550. [CrossRef]

42. Jawad, M.M.; Husein, A.; Azlina, A.; Alam, M.K.; Hassan, R.; Shaari, R. Effect of 940 nm low-level laser therapy on osteogenesis in vitro. J. Biomed. Opt. 2013, 18, 128001. [CrossRef]

43. Walter, C.; Pabst, A.M.; Ziebart, T. Effects of a low-level diode laser on oral keratinocytes, oral fibroblasts, endothelial cells and osteoblasts incubated with bisphosphonates: An in vitro study. Biomed. Rep. 2015, 3, 14-18. [CrossRef] [PubMed]

44. Shin, S.H.; Kim, K.H.; Choi, N.R.; Kim, I.R.; Park, B.S.; Kim, Y.D.; Kim, U.K.; Kim, C.H. Effect of low-level laser therapy on bisphosphonate-treated osteoblasts. Maxillofac. Plast Reconstr. Surg. 2016, 38, 48. [CrossRef] [PubMed]

45. Bolukbasi Ates, G.; Ak Can, A.; Gulsoy, M. Investigation of photobiomodulation potentiality by 635 and 809 nm lasers on human osteoblasts. Lasers Med. Sci. 2017, 32, 591-599. [CrossRef] [PubMed]

46. Ates, G.B.; Ak, A.; Garipcan, B.; Gulsoy, M. Indocyanine green-mediated photobiomodulation on human osteoblast cells. Lasers Med. Sci. 2018, 33, 1591-1599. [CrossRef] [PubMed]

47. Jeong, S.Y.; Hong, J.U.; Song, J.M.; Kim, I.R.; Park, B.S.; Kim, C.H.; Shin, S.H. Combined effect of recombinant human bone morphogenetic protein-2 and low level laser irradiation on bisphosphonate-treated osteoblasts. J. Korean Assoc. Oral. Maxillofac. Surg. 2018, 44, 259-268. [CrossRef] [PubMed]

48. Fujihara, N.A.; Hiraki, K.R.; Marques, M.M. Irradiation at $780 \mathrm{~nm}$ increases proliferation rate of osteoblasts independently of dexamethasone presence. Lasers Surg. Med. 2006, 38, 332-336. [CrossRef] [PubMed]

49. Fukuhara, E.; Goto, T.; Matayoshi, T.; Kobayashi, S.; Takahashi, T. Optimal low-energy laser irradiation causes temporal G2/M arrest on rat calvarial osteoblasts. Calcif. Tissue Int. 2006, 79, 443-450. [CrossRef] 
50. Shimizu, N.; Mayahara, K.; Kiyosaki, T.; Yamaguchi, A.; Ozawa, Y.; Abiko, Y. Low-intensity laser irradiation stimulates bone nodule formation via insulin-like growth factor-I expression in rat calvarial cells. Lasers Surg. Med. 2007, 39, 551-559. [CrossRef]

51. Xu, M.; Deng, T.; Mo, F.; Deng, B.; Lam, W.; Deng, P.; Zhang, X.; Liu, S. Low-intensity pulsed laser irradiation affects RANKL and OPG mRNA expression in rat calvarial cells. Photomed. Laser Surg. 2009, 27, 309-315. [CrossRef]

52. Ozawa, Y.; Shimizu, N.; Kariya, G.; Abiko, Y. Low-energy laser irradiation stimulates bone nodule formation at early stages of cell culture in rat calvarial cells. Bone 1998, 22, 347-354. [CrossRef]

53. Ueda, Y.; Shimizu, N. Pulse irradiation of low-power laser stimulates bone nodule formation. J. Oral. Sci. 2001, 43, 55-60. [CrossRef] [PubMed]

54. Ueda, Y.; Shimizu, N. Effects of pulse frequency of low-level laser therapy (LLLT) on bone nodule formation in rat calvarial cells. J. Clin. Laser Med. Surg. 2003, 21, 271-277. [CrossRef] [PubMed]

55. Khadra, M.; Lyngstadaas, S.P.; Haanaes, H.R.; Mustafa, K. Effect of laser therapy on attachment, proliferation and differentiation of human osteoblast-like cells cultured on titanium implant material. Biomaterials 2005, 26, 3503-3509. [CrossRef] [PubMed]

56. Cardoso, M.V.; do Vale Placa, R.; Sant'Ana, A.C.P.; Greghi, S.L.A.; Zangrando, M.S.R.; de Rezende, M.L.R.; Oliveira, R.C.; Damante, C.A. Laser and LED photobiomodulation effects in osteogenic or regular medium on rat calvaria osteoblasts obtained by newly forming bone technique. Lasers Med. Sci. 2020. [CrossRef]

57. Petri, A.D.; Teixeira, L.N.; Crippa, G.E.; Beloti, M.M.; de Oliveira, P.T.; Rosa, A.L. Effects of low-level laser therapy on human osteoblastic cells grown on titanium. Braz. Dent J. 2010, 21, 491-498. [CrossRef]

58. Emes, Y.A.K.; Aybar, B. Low-level laser therapy vs. pulsed electromagnetic field on neonatal rat calvarial osteoblast-like cells. Lasers Med. Sci. 2013, 28, 901-909. [CrossRef]

59. Morsoleto, M.; Sella, V.; Machado, P.; Bomfim, F.D.; Fernandes, M.H.; Morgado, F.; Lopes Filho, G.J.; Plapler, H. Effect of low power laser in biomodulation of cultured osteoblastic cells of Wistar rats1. Acta Cir. Bras 2019, 34, e201900210. [CrossRef]

60. Pires Oliveira, D.A.; de Oliveira, R.F.; Zangaro, R.A.; Soares, C.P. Evaluation of low-level laser therapy of osteoblastic cells. Photomed Laser Surg. 2008, 26, 401-404. [CrossRef]

61. Dortbudak, O.; Haas, R.; Mallath-Pokorny, G. Biostimulation of bone marrow cells with a diode soft laser. Clin. Oral. Implant. Res. 2000, 11, 540-545. [CrossRef]

62. Grassi, F.R.; Ciccolella, F.; D'Apolito, G.; Papa, F.; Iuso, A.; Salzo, A.E.; Trentadue, R.; Nardi, G.M.; Scivetti, M.; De Matteo, M.; et al. Effect of low-level laser irradiation on osteoblast proliferation and bone formation. J. Biol. Regul. Homeost. Agents 2011, 25, 603-614.

63. Mergoni, G.; Vescovi, P.; Belletti, S.; Uggeri, J.; Nammour, S.; Gatti, R. Effects of 915 nm laser irradiation on human osteoblasts: A preliminary in vitro study. Lasers Med. Sci. 2018, 33, 1189-1195. [CrossRef] [PubMed]

64. Hirata, S.; Kitamura, C.; Fukushima, H.; Nakamichi, I.; Abiko, Y.; Terashita, M.; Jimi, E. Low-level laser irradiation enhances BMP-induced osteoblast differentiation by stimulating the BMP/Smad signaling pathway. J. Cell Biochem. 2010, 111, 1445-1452. [CrossRef] [PubMed]

65. Ikeda, T.; Nomura, S.; Yamaguchi, A.; Suda, T.; Yoshiki, S. In situ hybridization of bone matrix proteins in undecalcified adult rat bone sections. J. Histochem. Cytochem. 1992, 40, 1079-1088. [CrossRef] [PubMed]

66. Komori, T. Molecular Mechanism of Runx2-Dependent Bone Development. Mol. Cells 2020, 43, 168-175.

67. Nakashima, K.; Zhou, X.; Kunkel, G.; Zhang, Z.; Deng, J.M.; Behringer, R.R.; de Crombrugghe, B. The Novel Zinc Finger-Containing Transcription Factor Osterix Is Required for Osteoblast Differentiation and Bone Formation. Cell 2002, 108, 17-29. [CrossRef]

68. Miyazono, K.; Kamiya, Y.; Morikawa, M. Bone morphogenetic protein receptors and signal transduction. J. Biochem. 2010, 147, 35-51. [CrossRef]

69. Heldin, C.H.; Miyazono, K.; ten Dijke, P. TGF-beta signalling from cell membrane to nucleus through SMAD proteins. Nature 1997, 390, 465-471. [CrossRef]

70. Fujihara, S.; Yokozeki, M.; Oba, Y.; Higashibata, Y.; Nomura, S.; Moriyama, K. Function and regulation of osteopontin in response to mechanical stress. J. Bone Min. Res. 2006, 21, 956-964. [CrossRef]

71. Miyazono, K.; Kusanagi, K.; Inoue, H. Divergence and convergence of TGF-beta/BMP signaling. J. Cell Physiol. 2001, 187, 265-276. [CrossRef] 
72. Ryoo, H.M.; Hoffmann, H.M.; Beumer, T.; Frenkel, B.; Towler, D.A.; Stein, G.S.; Stein, J.L.; van Wijnen, A.J.; Lian, J.B. Stage-specific expression of Dlx5 during osteoblast differentiation: Involvement in regulation of osteocalcin gene expression. Mol. Endocrinol. 1997, 11, 1681-1694. [CrossRef]

73. Deckx, S.; Heymans, S.; Papageorgiou, A.P. The diverse functions of osteoglycin: A deceitful dwarf, or a master regulator of disease? Faseb J. Off. Publ. Fed. Am. Soc. Exp. Biol. 2016, 30, 2651-2661. [CrossRef] [PubMed]

74. Starup-Linde, J.; Viggers, R.; Handberg, A. Osteoglycin and Bone-a Systematic Review. Curr. Osteoporos. Rep. 2019, 17, 250-255. [CrossRef] [PubMed]

75. Arisu, H.D.; Turkoz, E.; Bala, O. Effects of Nd:Yag laser irradiation on osteoblast cell cultures. Lasers Med. Sci. 2006, 21, 175-180. [CrossRef] [PubMed]

76. Chellini, F.; Sassoli, C.; Nosi, D.; Deledda, C.; Tonelli, P.; Zecchi-Orlandini, S.; Formigli, L.; Giannelli, M. Low pulse energy Nd:YAG laser irradiation exerts a biostimulative effect on different cells of the oral microenvironment: "an in vitro study". Lasers Surg. Med. 2010, 42, 527-539. [CrossRef]

77. Kara, C.; Selamet, H.; Gokmenoglu, C.; Kara, N. Low level laser therapy induces increased viability and proliferation in isolated cancer cells. Cell Prolif. 2018, 51, e12417. [CrossRef]

78. Tsuka, Y.; Kunimatsu, R.; Gunji, H.; Nakajima, K.; Kimura, A.; Hiraki, T.; Nakatani, A.; Tanimoto, K. Effects of Nd:YAG low-level laser irradiation on cultured human osteoblasts migration and ATP production: In vitro study. Lasers Med. Sci. 2019, 34, 55-60. [CrossRef]

79. Tsuka, Y.; Kunimatsu, R.; Gunji, H.; Abe, T.; Medina, C.C.; Nakajima, K.; Kimura, A.; Hiraki, T.; Nakatani, A.; Tanimoto, K. Examination of the Effect of the Combined Use of Nd: YAG Laser Irradiation and Mechanical Force Loading on Bone Metabolism Using Cultured Human Osteoblasts. J. Lasers Med. Sci. 2020, 11, 138-143. [CrossRef]

80. Kim, I.S.; Cho, T.H.; Kim, K.; Weber, F.E.; Hwang, S.J. High power-pulsed Nd:YAG laser as a new stimulus to induce BMP-2 expression in MC3T3-E1 osteoblasts. Lasers Surg. Med. 2010, 42, 510-518. [CrossRef]

81. Middleton, J.; Arnott, N.; Walsh, S.; Beresford, J. Osteoblasts and osteoclasts in adult human osteophyte tissue express the mRNAs for insulin-like growth factors I and II and the type 1 IGF receptor. Bone 1995, 16, 287-293. [CrossRef]

82. Schwarz, F.; Rothamel, D.; Herten, M.; Bieling, K.; Scherbaum, W.; Becker, J. Effects of an Er:YAG laser on mitochondrial activity of human osteosarcoma-derived osteoblasts in vitro. Lasers Med. Sci. 2004, 19, 37-40. [CrossRef]

83. Aleksic, V.; Aoki, A.; Iwasaki, K.; Takasaki, A.A.; Wang, C.Y.; Abiko, Y.; Ishikawa, I.; Izumi, Y. Low-level Er:YAG laser irradiation enhances osteoblast proliferation through activation of MAPK/ERK. Lasers Med. Sci. 2010, 25, 559-569. [CrossRef] [PubMed]

84. Niimi, H.; Ohsugi, Y.; Katagiri, S.; Watanabe, K.; Hatasa, M.; Shimohira, T.; Tsuchiya, Y.; Maekawa, S.; Hirota, T.; Kadokura, H.; et al. Effects of Low-Level Er:YAG Laser Irradiation on Proliferation and Calcification of Primary Osteoblast-Like Cells Isolated From Rat Calvaria. Front. Cell Dev. Biol. 2020, 8, 459. [CrossRef] [PubMed]

85. Cargnello, M.; Roux, P.P. Activation and function of the MAPKs and their substrates, the MAPK-activated protein kinases. Microbiol. Mol. Biol. Rev. 2011, 75, 50-83. [CrossRef] [PubMed]

86. Kawaki, H.; Kubota, S.; Suzuki, A.; Suzuki, M.; Kohsaka, K.; Hoshi, K.; Fujii, T.; Lazar, N.; Ohgawara, T.; Maeda, T.; et al. Differential roles of CCN family proteins during osteoblast differentiation: Involvement of Smad and MAPK signaling pathways. Bone 2011, 49, 975-989. [CrossRef]

87. Lin, G.L.; Hankenson, K.D. Integration of BMP, Wnt, and notch signaling pathways in osteoblast differentiation. J. Cell Biochem. 2011, 112, 3491-3501. [CrossRef]

88. Sasaki, Y.; Wang, S.; Ogata, Y. Transcriptional regulation of bone sialoprotein gene by $\mathrm{CO}(2)$ laser irradiation. J. Oral. Sci. 2011, 53, 51-59. [CrossRef]

89. Dekoninck, S.; Blanpain, C. Stem cell dynamics, migration and plasticity during wound healing. Nat. Cell Biol. 2019, 21, 18-24. [CrossRef]

90. Bainbridge, P. Wound healing and the role of fibroblasts. J. Wound Care 2013, 22, 407-411.

91. Grinnell, F. Fibroblasts, myofibroblasts, and wound contraction. J. Cell Biol. 1994, 124, 401-404. [CrossRef]

92. Hamblin, M.R. Mechanisms and applications of the anti-inflammatory effects of photobiomodulation. Aims Biophys. 2017, 4, 337-361. [CrossRef]

93. Solmaz, H.; Dervisoglu, S.; Gulsoy, M.; Ulgen, Y. Laser biostimulation of wound healing: Bioimpedance measurements support histology. Lasers Med. Sci. 2016, 31, 1547-1554. [CrossRef] [PubMed] 
94. Sakurai, Y.; Yamaguchi, M.; Abiko, Y. Inhibitory effect of low-level laser irradiation on LPS-stimulated prostaglandin E2 production and cyclooxygenase-2 in human gingival fibroblasts. Eur. J. Oral. Sci. 2000, 108, 29-34. [CrossRef] [PubMed]

95. Takema, T.; Yamaguchi, M.; Abiko, Y. Reduction of Plasminogen Activator Activity Stimulated by Lipopolysaccharide from Periodontal Pathogen in Human Gingival Fibroblasts by Low-energy Laser Irradiation. Lasers Med. Sci. 2000, 15, 35-42. [CrossRef] [PubMed]

96. Nomura, K.; Yamaguchi, M.; Abiko, Y. Inhibition of interleukin-1beta production and gene expression in human gingival fibroblasts by low-energy laser irradiation. Lasers Med. Sci. 2001, 16, 218-223. [CrossRef]

97. Almeida-Lopes, L.; Rigau, J.; Zângaro, R.A.; Guidugli-Neto, J.; Jaeger, M.M. Comparison of the low level laser therapy effects on cultured human gingival fibroblasts proliferation using different irradiance and same fluence. Lasers Surg. Med. 2001, 29, 179-184. [CrossRef]

98. Basso, F.G.; Pansani, T.N.; Turrioni, A.P.; Bagnato, V.S.; Hebling, J.; de Souza Costa, C.A. In vitro wound healing improvement by low-level laser therapy application in cultured gingival fibroblasts. Int. J. Dent 2012, 2012, 719452. [CrossRef]

99. Frozanfar, A.; Ramezani, M.; Rahpeyma, A.; Khajehahmadi, S.; Arbab, H.R. The Effects of Low Level Laser Therapy on the Expression of Collagen Type I Gene and Proliferation of Human Gingival Fibroblasts (Hgf3-Pi 53): In vitro Study. Iran J. Basic Med. Sci. 2013, 16, 1071-1074.

100. Saygun, I.; Karacay, S.; Serdar, M.; Ural, A.U.; Sencimen, M.; Kurtis, B. Effects of laser irradiation on the release of basic fibroblast growth factor (bFGF), insulin like growth factor-1 (IGF-1), and receptor of IGF-1 (IGFBP3) from gingival fibroblasts. Lasers Med. Sci. 2008, 23, 211-215. [CrossRef]

101. Basso, F.G.; Pansani, T.N.; Soares, D.G.; Scheffel, D.L.; Bagnato, V.S.; de Souza Costa, C.A.; Hebling, J. Biomodulation of Inflammatory Cytokines Related to Oral Mucositis by Low-Level Laser Therapy. Photochem. Photobiol. 2015, 91, 952-956. [CrossRef]

102. Hakki, S.S.; Bozkurt, S.B. Effects of different setting of diode laser on the mRNA expression of growth factors and type I collagen of human gingival fibroblasts. Lasers Med. Sci. 2012, 27, 325-331. [CrossRef]

103. Damante, C.A.; De Micheli, G.; Miyagi, S.P.; Feist, I.S.; Marques, M.M. Effect of laser phototherapy on the release of fibroblast growth factors by human gingival fibroblasts. Lasers Med. Sci. 2009, 24, 885-891. [CrossRef] [PubMed]

104. Kreisler, M.; Daubländer, M.; Willershausen-Zönnchen, B.; d'Hoedt, B. Effect of diode laser irradiation on the survival rate of gingival fibroblast cell cultures. Lasers Surg. Med. 2001, 28, 445-450. [CrossRef] [PubMed]

105. Pereira, A.N.; Eduardo Cde, P.; Matson, E.; Marques, M.M. Effect of low-power laser irradiation on cell growth and procollagen synthesis of cultured fibroblasts. Lasers Surg. Med. 2002, 31, 263-267. [CrossRef] [PubMed]

106. Sassoli, C.; Chellini, F.; Squecco, R.; Tani, A.; Idrizaj, E.; Nosi, D.; Giannelli, M.; Zecchi-Orlandini, S. Low intensity $635 \mathrm{~nm}$ diode laser irradiation inhibits fibroblast-myofibroblast transition reducing TRPC1 channel expression/activity: New perspectives for tissue fibrosis treatment. Lasers Surg. Med. 2016, 48, 318-332. [CrossRef]

107. Kaibuchi, N.; Iwata, T.; Yamato, M.; Okano, T.; Ando, T. Multipotent mesenchymal stromal cell sheet therapy for bisphosphonate-related osteonecrosis of the jaw in a rat model. Acta Biomater. 2016, 42, 400-410. [CrossRef]

108. Marques, M.M.; Pereira, A.N.; Fujihara, N.A.; Nogueira, F.N.; Eduardo, C.P. Effect of low-power laser irradiation on protein synthesis and ultrastructure of human gingival fibroblasts. Lasers Surg. Med. 2004, 34, 260-265. [CrossRef]

109. Castro, D.J.; Abergel, R.P.; Meeker, C.; Dwyer, R.M.; Lesavoy, M.A.; Uitto, J. Effects of the Nd:YAG laser on DNA synthesis and collagen production in human skin fibroblast cultures. Ann. Plast Surg. 1983, 11, 214-222. [CrossRef]

110. Abergel, R.P.; Meeker, C.A.; Dwyer, R.M.; Lesavoy, M.A.; Uitto, J. Nonthermal effects of ND:YAG laser on biological functions of human skin fibroblasts in culture. Lasers Surg. Med. 1984, 3, 279-284. [CrossRef]

111. Cisneros, J.L.; Río, R.; Palou, J. The Q-switched neodymium (Nd):YAG laser with quadruple frequency. Clinical histological evaluation of facial resurfacing using different wavelengths. Derm. Surg. 1998, 24, 345-350. [CrossRef]

112. Jansen, P.L.; Rosch, R.; Jansen, M.; Binnebösel, M.; Junge, K.; Alfonso-Jaume, A.; Klinge, U.; Lovett, D.H.; Mertens, P.R. Regulation of MMP-2 gene transcription in dermal wounds. J. Investig. Derm. 2007, 127, 1762-1767. [CrossRef] [PubMed] 
113. De Filippis, A.; Perfetto, B.; Guerrera, L.P.; Oliviero, G.; Baroni, A. Q-switched 1064 nm Nd-Yag nanosecond laser effects on skin barrier function and on molecular rejuvenation markers in keratinocyte-fibroblasts interaction. Lasers Med. Sci. 2019, 34, 595-605. [CrossRef] [PubMed]

114. Ye, X.; Wang, L.; Dang, Y.; Liu, B.; Zhao, D. Investigation of the $1064 \mathrm{~nm}$ Q-switched Nd:YAG laser on collagen expression in an animal model. Photomed. Laser Surg. 2012, 30, 604-609. [CrossRef] [PubMed]

115. Dang, Y.; Ye, X.; Weng, Y.; Tong, Z.; Ren, Q. Effects of the 532-nm and 1064-nm Q-switched Nd: YAG lasers on collagen turnover of cultured human skin fibroblasts: A comparative study. Lasers Med. Sci. 2010, 25, 719-726. [CrossRef] [PubMed]

116. Watanabe, H.; Ishikawa, I.; Suzuki, M.; Hasegawa, K. Clinical assessments of the erbium:YAG laser for soft tissue surgery and scaling. J. Clin. Laser Med. Surg. 1996, 14, 67-75. [CrossRef]

117. Aoki, A.; Mizutani, K.; Takasaki, A.A.; Sasaki, K.M.; Nagai, S.; Schwarz, F.; Yoshida, I.; Eguro, T.; Zeredo, J.L.; Izumi, Y. Current status of clinical laser applications in periodontal therapy. Gen Dent 2008, 56, 674-687, quiz 688-9, 767.

118. Pourzarandian, A.; Watanabe, H.; Ruwanpura, S.M.; Aoki, A.; Ishikawa, I. Effect of low-level Er:YAG laser irradiation on cultured human gingival fibroblasts. J. Periodontol. 2005, 76, 187-193. [CrossRef]

119. Pourzarandian, A.; Watanabe, H.; Ruwanpura, S.M.; Aoki, A.; Noguchi, K.; Ishikawa, I. Er:YAG laser irradiation increases prostaglandin E production via the induction of cyclooxygenase- 2 mRNA in human gingival fibroblasts. J. Periodontal Res. 2005, 40, 182-186. [CrossRef]

120. Ogita, M.; Tsuchida, S.; Aoki, A.; Satoh, M.; Kado, S.; Sawabe, M.; Nanbara, H.; Kobayashi, H.; Takeuchi, Y.; Mizutani, K.; et al. Increased cell proliferation and differential protein expression induced by low-level Er:YAG laser irradiation in human gingival fibroblasts: Proteomic analysis. Lasers Med. Sci. 2015, 30, 1855-1866. [CrossRef]

121. Kong, S.; Aoki, A.; Iwasaki, K.; Mizutani, K.; Katagiri, S.; Suda, T.; Ichinose, S.; Ogita, M.; Pavlic, V.; Izumi, Y. Biological effects of Er:YAG laser irradiation on the proliferation of primary human gingival fibroblasts. J. Biophotonics 2018, 11, 201700157. [CrossRef]

122. Talebi-Ardakani, M.R.; Torshabi, M.; Karami, E.; Arbabi, E.; Rezaei Esfahrood, Z. In Vitro Study of Er:YAG and Er, Cr:YSGG Laser Irradiation on Human Gingival Fibroblast Cell Line. Acta Med. Iran 2016, 54, $251-255$.

123. Tsuka, Y.; Kunimatsu, R.; Gunji, H.; Abe, T.; Medina, C.C.; Hiraki, T.; Nakatani, A.; Sakata, S.; Rikitake, K.; Aisyah, P.N.; et al. Examination of the effect of combined use of Er:YAG laser irradiation and mechanical force loading on bone metabolism using primary human gingival fibroblasts. Lasers Med. Sci. 2020, 35, 2059-2064. [CrossRef] [PubMed]

124. Thomson, P.J.; Wylie, J. Interventional laser surgery: An effective surgical and diagnostic tool in oral precancer management. Int. J. Oral. Maxillofac. Surg. 2002, 31, 145-153. [CrossRef] [PubMed]

125. Iwasaka, K.; Hemmi, E.; Tomita, K.; Ishihara, S.; Katayama, T.; Sakagami, H. Effect of $\mathrm{CO}_{2}$ laser irradiation on hormesis induction in human pulp and periodontal ligament fibroblasts. In Vivo 2011, 25, 787-793. [PubMed]

126. Pant, V.; Dixit, J.; Agrawal, A.K.; Seth, P.K.; Pant, A.B. Behavior of human periodontal ligament cells on $\mathrm{CO}_{2}$ laser irradiated dentinal root surfaces: An in vitro study. J. Periodontal Res. 2004, 39, 373-379. [CrossRef]

127. Yamasaki, A.; Tamamura, K.; Sakurai, Y.; Okuyama, N.; Yusa, J.; Ito, H. Remodeling of the rat gingiva induced by $\mathrm{CO}_{2}$ laser coagulation mode. Lasers Surg. Med. 2008, 40, 695-703. [CrossRef]

128. Nowak, K.C.; McCormack, M.; Koch, R.J. The effect of superpulsed carbon dioxide laser energy on keloid and normal dermal fibroblast secretion of growth factors: A serum-free study. Plast Reconstr. Surg. 2000, 105, 2039-2048. [CrossRef]

129. Shingyochi, Y.; Kanazawa, S.; Tajima, S.; Tanaka, R.; Mizuno, H.; Tobita, M. A Low-Level Carbon Dioxide Laser Promotes Fibroblast Proliferation and Migration through Activation of Akt, ERK, and JNK. PLoS ONE 2017, 12, e0168937. [CrossRef]

130. Apfelberg, D.B.; Mittelman, H.; Chadi, B. Carcinogenic potential of in vitro carbon dioxide laser exposure of fibroblast. Obs. Gynecol. 1983, 61, 493-496.

131. Barczyk, M.; Bolstad, A.I.; Gullberg, D. Role of integrins in the periodontal ligament: Organizers and facilitators. Periodontoloy 2000 2013, 63, 29-47. [CrossRef]

132. Wu, J.Y.; Chen, C.H.; Yeh, L.Y.; Yeh, M.L.; Ting, C.C.; Wang, Y.H. Low-power laser irradiation promotes the proliferation and osteogenic differentiation of human periodontal ligament cells via cyclic adenosine monophosphate. Int. J. Oral. Sci. 2013, 5, 85-91. [CrossRef] 
133. Huang, T.H.; Chen, C.C.; Liu, S.L.; Lu, Y.C.; Kao, C.T. A low-level diode laser therapy reduces the lipopolysaccharide (LPS)-induced periodontal ligament cell inflammation. Laser Phys. Lett. 2014, 11, 075602. [CrossRef]

134. Mayahara, K.; Yamaguchi, A.; Sakaguchi, M.; Igarashi, Y.; Shimizu, N. Effect of Ga-Al-As laser irradiation on COX-2 and cPLA2-alpha expression in compressed human periodontal ligament cells. Lasers Surg. Med. 2010, 42, 489-493. [CrossRef] [PubMed]

135. Shimizu, N.; Yamaguchi, M.; Goseki, T.; Shibata, Y.; Takiguchi, H.; Iwasawa, T.; Abiko, Y. Inhibition of prostaglandin E2 and interleukin 1-beta production by low-power laser irradiation in stretched human periodontal ligament cells. J. Dent Res. 1995, 74, 1382-1388. [CrossRef]

136. Ozawa, Y.; Shimizu, N.; Abiko, Y. Low-energy diode laser irradiation reduced plasminogen activator activity in human periodontal ligament cells. Lasers Surg. Med. 1997, 21, 456-463. [CrossRef]

137. Huang, T.H.; Liu, S.L.; Chen, C.L.; Shie, M.Y.; Kao, C.T. Low-level laser effects on simulated orthodontic tension side periodontal ligament cells. Photomed. Laser Surg. 2013, 31, 72-77. [CrossRef] [PubMed]

138. Choi, E.J.; Yim, J.Y.; Koo, K.T.; Seol, Y.J.; Lee, Y.M.; Ku, Y.; Rhyu, I.C.; Chung, C.P.; Kim, T.I. Biological effects of a semiconductor diode laser on human periodontal ligament fibroblasts. J. Periodontal. Implant Sci. 2010, 40, 105-110. [CrossRef] [PubMed]

139. Dehdashtizadeh, A.; Esnaashari, N.; Farhad, S.Z.; Ejeian, F.; Amini, S. The effect of laser irradiation and doxycycline application on the production of matrix metalloproteinase- 8 and collagen I from cultured human periodontal ligament cells. Dent. Res. J. Isfahan 2020, 17, 213-218. [PubMed]

140. Kreisler, M.; Christoffers, A.B.; Willershausen, B.; d'Hoedt, B. Effect of low-level GaAlAs laser irradiation on the proliferation rate of human periodontal ligament fibroblasts: An in vitro study. J. Clin. Periodontol. 2003, 30, 353-358. [CrossRef]

141. Lin, T.; Yu, C.C.; Liu, C.M.; Hsieh, P.L.; Liao, Y.W.; Yu, C.H.; Chen, C.J. Er:YAG laser promotes proliferation and wound healing capacity of human periodontal ligament fibroblasts through Galectin-7 induction. J. Med. Assoc. 2020. [CrossRef]

142. Peplow, P.V.; Chung, T.Y.; Baxter, G.D. Laser photobiomodulation of wound healing: A review of experimental studies in mouse and rat animal models. Photomed. Laser Surg. 2010, 28, 291-325. [CrossRef]

143. Schwarz, F.; Aoki, A.; Sculean, A.; Becker, J. The impact of laser application on periodontal and peri-implant wound healing. Periodontology 2000 2009, 51, 79-108. [CrossRef] [PubMed]

144. Vannella, K.M.; Wynn, T.A. Mechanisms of Organ Injury and Repair by Macrophages. Annu. Rev. Physiol. 2017, 79, 593-617. [CrossRef] [PubMed]

145. Amaroli, A.; Ravera, S.; Baldini, F.; Benedicenti, S.; Panfoli, I.; Vergani, L. Photobiomodulation with 808-nm diode laser light promotes wound healing of human endothelial cells through increased reactive oxygen species production stimulating mitochondrial oxidative phosphorylation. Lasers Med. Sci. 2019, 34, 495-504. [CrossRef] [PubMed]

146. Protasiewicz, M.; Kuliczkowski, W.; Woznicka, A.K.; Szymkiewicz, P.; Derkacz, A.; Andrzej, M.; Dziegiel, P. Influence of low-power laser illumination on pro-inflammatory response in human endothelial cells stimulated with interleukin-1a. In Vivo 2013, 27, 313-319.

147. Schindl, A.; Merwald, H.; Schindl, L.; Kaun, C.; Wojta, J. Direct stimulatory effect of low-intensity $670 \mathrm{~nm}$ laser irradiation on human endothelial cell proliferation. Br. J. Derm. 2003, 148, 334-336. [CrossRef]

148. Góralczyk, K.; Szymańska, J.; Łukowicz, M.; Drela, E.; Kotzbach, R.; Dubiel, M.; Michalska, M.; Góralczyk, B.; Zając, A.; Rość, D. Effect of LLLT on endothelial cells culture. Lasers Med. Sci. 2015, 30, 273-278. [CrossRef]

149. Du, S.; Zhang, Q.; Zhang, S.; Wang, L.; Lian, J. Heat shock protein 70 expression induced by diode laser irradiation on choroid-retinal endothelial cells in vitro. Mol. Vis. 2012, 18, 2380-2387.

150. Masuda, Y.; Yokose, S.; Sakagami, H. Gene Expression Analysis of Cultured Rat-Endothelial Cells after Nd:YAG Laser Irradiation by Affymetrix GeneChip Array. In Vivo 2017, 31, 51-54. [CrossRef]

151. Giannelli, M.; Bani, D.; Tani, A.; Pini, A.; Margheri, M.; Zecchi-Orlandini, S.; Tonelli, P.; Formigli, L. In vitro evaluation of the effects of low-intensity Nd:YAG laser irradiation on the inflammatory reaction elicited by bacterial lipopolysaccharide adherent to titanium dental implants. J. Periodontol. 2009, 80,977-984. [CrossRef]

152. Saygin, N.E.; Giannobile, W.V.; Somerman, M.J. Molecular and cell biology of cementum. Periodontoloy 2000 2000, 24, 73-98. [CrossRef]

153. Bozkurt, S.B.; Hakki, E.E.; Kayis, S.A.; Dundar, N.; Hakki, S.S. Biostimulation with diode laser positively regulates cementoblast functions, in vitro. Lasers Med. Sci. 2017, 32, 911-919. [CrossRef] [PubMed] 
154. Kalluri, R.; Weinberg, R.A. The basics of epithelial-mesenchymal transition. J. Clin. Investig. 2009, 119, 1420-1428. [CrossRef] [PubMed]

155. Rathinam, V.A.K.; Chan, F.K. Inflammasome, Inflammation, and Tissue Homeostasis. Trends Mol. Med. 2018, 24, 304-318. [CrossRef] [PubMed]

156. de Farias Gabriel, A.; Wagner, V.P.; Correa, C.; Webber, L.P.; Pilar, E.F.S.; Curra, M.; Carrard, V.C.; Martins, M.A.T.; Martins, M.D. Photobiomodulation therapy modulates epigenetic events and NF-kappaB expression in oral epithelial wound healing. Lasers Med. Sci. 2019, 34, 1465-1472. [CrossRef]

157. Luomanen, M.; Rauhamaa-Makinen, R.; Meurman, J.H.; Kosloff, T.; Tiitta, O. Healing of rat mouth mucosa after irradiation with $\mathrm{CO}_{2}, \mathrm{Nd}: \mathrm{YAG}$, and $\mathrm{CO}_{2}-\mathrm{Nd}$ YAG combination lasers. Scand. J. Dent. Res. 1994, 102, 223-228. [CrossRef]

158. Sawabe, M.; Aoki, A.; Komaki, M.; Iwasaki, K.; Ogita, M.; Izumi, Y. Gingival tissue healing following Er:YAG laser ablation compared to electrosurgery in rats. Lasers Med. Sci. 2015, 30, 875-883. [CrossRef]

159. Posten, W.; Wrone, D.A.; Dover, J.S.; Arndt, K.A.; Silapunt, S.; Alam, M. Low-level laser therapy for wound healing: Mechanism and efficacy. Derm. Surg. 2005, 31, 334-340. [CrossRef]

160. Grossman, N.; Schneid, N.; Reuveni, H.; Halevy, S.; Lubart, R. $780 \mathrm{~nm}$ low power diode laser irradiation stimulates proliferation of keratinocyte cultures: Involvement of reactive oxygen species. Lasers Surg. Med. 1998, 22, 212-218. [CrossRef]

161. Basso, F.G.; Oliveira, C.F.; Kurachi, C.; Hebling, J.; Costa, C.A. Biostimulatory effect of low-level laser therapy on keratinocytes in vitro. Lasers Med. Sci. 2013, 28, 367-374. [CrossRef]

162. Donnarumma, G.; De Gregorio, V.; Fusco, A.; Farina, E.; Baroni, A.; Esposito, V.; Contaldo, M.; Petruzzi, M.; Pannone, G.; Serpico, R. Inhibition of HSV-1 replication by laser diode-irradiation: Possible mechanism of action. Int. J. Immunopathol. Pharm. 2010, 23, 1167-1176. [CrossRef]

163. Yang, H.Q.; Wang, Y.H.; Chen, J.X.; Zheng, L.Q.; Xie, S.S. [Low level laser irradiation in the visible spectra induces HeLa cells proliferation]. Spectrosc. Spectr. Anal. 2012, 32, 1024-1027.

164. Mognato, M.; Squizzato, F.; Facchin, F.; Zaghetto, L.; Corti, L. Cell growth modulation of human cells irradiated in vitro with low-level laser therapy. Photomed. Laser Surg. 2004, 22, 523-526. [CrossRef] [PubMed]

165. Szabó, A.; Varga, V.; Toimela, T.; Hiitelä, K.; Tähti, H.; Oja, S.S.; Süveges, I.; Salminen, L. Laser treatment of cultured retinal pigment epithelial cells-evaluation of the cellular damage in vitro. J. Ocul. Pharm. 2004, 20, 246-255. [CrossRef] [PubMed]

166. Barak, A.; Goldkorn, T.; Morse, L.S. Laser induces apoptosis and ceramide production in human retinal pigment epithelial cells. Investig. Ophthalmol. Vis. Sci. 2005, 46, 2587-2591. [CrossRef] [PubMed]

167. Hattenbach, L.O.; Beck, K.F.; Pfeilschifter, J.; Koch, F.; Ohrloff, C.; Schacke, W. Pigment-epithelium-derived factor is upregulated in photocoagulated human retinal pigment epithelial cells. Ophthalmic Res. 2005, 37, 341-346. [CrossRef]

168. Powell, K.; Low, P.; McDonnell, P.A.; Laakso, E.L.; Ralph, S.J. The effect of laser irradiation on proliferation of human breast carcinoma, melanoma, and immortalized mammary epithelial cells. Photomed. Laser Surg. 2010, 28, 115-123. [CrossRef]

169. Tang, E.; Khan, I.; Andreana, S.; Arany, P.R. Laser-activated transforming growth factor- $\beta 1$ induces human $\beta$-defensin 2: Implications for laser therapies for periodontitis and peri-implantitis. J. Periodontal. Res. 2017, 52, 360-367. [CrossRef]

170. Ejiri, K.; Aoki, A.; Yamaguchi, Y.; Ohshima, M.; Izumi, Y. High-frequency low-level diode laser irradiation promotes proliferation and migration of primary cultured human gingival epithelial cells. Lasers Med. Sci. 2014, 29, 1339-1347. [CrossRef]

171. Nagahara, A.; Mitani, A.; Fukuda, M.; Yamamoto, H.; Tahara, K.; Morita, I.; Ting, C.C.; Watanabe, T.; Fujimura, T.; Osawa, K.; et al. Antimicrobial photodynamic therapy using a diode laser with a potential new photosensitizer, indocyanine green-loaded nanospheres, may be effective for the clearance of Porphyromonas gingivalis. J. Periodontal. Res. 2013, 48, 591-599. [CrossRef]

172. Fujimura, T.; Mitani, A.; Fukuda, M.; Mogi, M.; Osawa, K.; Takahashi, S.; Aino, M.; Iwamura, Y.; Miyajima, S.; Yamamoto, H.; et al. Irradiation with a low-level diode laser induces the developmental endothelial locus-1 gene and reduces proinflammatory cytokines in epithelial cells. Lasers Med. Sci 2014, 29, 987-994. [CrossRef]

173. Yokose, S.K.H. Low-power carbon dioxide laser irradiation reduces sclerostin expression, but stimulates Dmp-1 expression in osteocyte-like cells of rats. J. Bio-Integ. 2013, 3, 8. [CrossRef] 
174. Ohsugi, Y.; Katagiri, S.; Hirota, T.; Niimi, H.; Hatasa, M.; Watanabe, K.; Shimohira, T.; Mizutani, K.; Kitazawa, M.; Matsuzawa, A.; et al. Laser irradiation decreases sclerostin expression in bone and osteogenic cells. Faseb. J. 2020. [CrossRef]

175. Suda, T.; Takahashi, N.; Udagawa, N.; Jimi, E.; Gillespie, M.T.; Martin, T.J. Modulation of osteoclast differentiation and function by the new members of the tumor necrosis factor receptor and ligand families. Endocr. Rev. 1999, 20, 345-357. [CrossRef]

176. Aihara, N.; Yamaguchi, M.; Kasai, K. Low-energy irradiation stimulates formation of osteoclast-like cells via RANK expression in vitro. Lasers Med. Sci. 2006, 21, 24-33. [CrossRef]

177. Atala, A.L.R. Handbook of Stem Cells; Academic Press: Cambridge, MA, USA, 2012; Volume 452.

178. Mvula, B.; Mathope, T.; Moore, T.; Abrahamse, H. The effect of low level laser irradiation on adult human adipose derived stem cells. Lasers Med. Sci. 2008, 23, 277-282. [CrossRef] [PubMed]

179. Seo, B.M.; Miura, M.; Gronthos, S.; Bartold, P.M.; Batouli, S.; Brahim, J.; Young, M.; Robey, P.G.; Wang, C.Y.; Shi, S. Investigation of multipotent postnatal stem cells from human periodontal ligament. Lancet 2004, 364, 149-155. [CrossRef]

180. Gronthos, S.; Mankani, M.; Brahim, J.; Robey, P.G.; Shi, S. Postnatal human dental pulp stem cells (DPSCs) in vitro and in vivo. Proc. Natl. Acad. Sci. USA 2000, 97, 13625-13630. [CrossRef] [PubMed]

181. Gurtner, G.C.; Callaghan, M.J.; Longaker, M.T. Progress and potential for regenerative medicine. Annu. Rev. Med. 2007, 58, 299-312. [CrossRef] [PubMed]

182. Zare, F.; Moradi, A.; Fallahnezhad, S.; Ghoreishi, S.K.; Amini, A.; Chien, S.; Bayat, M. Photobiomodulation with 630 plus $810 \mathrm{~nm}$ wavelengths induce more in vitro cell viability of human adipose stem cells than human bone marrow-derived stem cells. J. Photochem. Photobiol. BBiol. 2019, 201, 111658. [CrossRef]

183. Wu, Y.H.; Wang, J.; Gong, D.X.; Gu, H.Y.; Hu, S.S.; Zhang, H. Effects of low-level laser irradiation on mesenchymal stem cell proliferation: A microarray analysis. Lasers Med. Sci. 2012, 27, 509-519. [CrossRef]

184. Hou, J.F.; Zhang, H.; Yuan, X.; Li, J.; Wei, Y.J.; Hu, S.S. In vitro effects of low-level laser irradiation for bone marrow mesenchymal stem cells: Proliferation, growth factors secretion and myogenic differentiation. Lasers Surg. Med. 2008, 40, 726-733. [CrossRef] [PubMed]

185. Giannelli, M.; Chellini, F.; Sassoli, C.; Francini, F.; Pini, A.; Squecco, R.; Nosi, D.; Bani, D.; Zecchi-Orlandini, S.; Formigli, L. Photoactivation of bone marrow mesenchymal stromal cells with diode laser: Effects and mechanisms of action. J. Cell. Physiol. 2013, 228, 172-181. [CrossRef] [PubMed]

186. Feng, J.; Li, X.; Zhu, S.; Xie, Y.; Du, J.; Ge, H.; Bai, Y.; Liu, Y.; Guo, L. Photobiomodulation with 808-nm diode laser enhances gingival wound healing by promoting migration of human gingival mesenchymal stem cells via ROS/JNK/NF-kappaB/MMP-1 pathway. Lasers Med. Sci. 2020, 35, 1831-1839. [CrossRef] [PubMed]

187. Amaroli, A.; Agas, D.; Laus, F.; Cuteri, V.; Hanna, R.; Sabbieti, M.G.; Benedicenti, S. The Effects of Photobiomodulation of $808 \mathrm{~nm}$ Diode Laser Therapy at Higher Fluence on the in Vitro Osteogenic Differentiation of Bone Marrow Stromal Cells. Front. Physiol. 2018, 9, 123. [CrossRef]

188. Horvat-Karajz, K.; Balogh, Z.; Kovacs, V.; Drrernat, A.H.; Sreter, L.; Uher, F. In vitro effect of carboplatin, cytarabine, paclitaxel, vincristine, and low-power laser irradiation on murine mesenchymal stem cells. Lasers Surg. Med. 2009, 41, 463-469. [CrossRef]

189. Ferreira, L.S.; Diniz, I.M.A.; Maranduba, C.M.S.; Miyagi, S.P.H.; Rodrigues, M.; Moura-Netto, C.; Marques, M.M. Short-term evaluation of photobiomodulation therapy on the proliferation and undifferentiated status of dental pulp stem cells. Lasers Med. Sci. 2019, 34, 659-666. [CrossRef]

190. Garrido, P.R.; Pedroni, A.C.F.; Cury, D.P.; Moreira, M.S.; Rosin, F.; Sarra, G.; Marques, M.M. Effects of photobiomodulation therapy on the extracellular matrix of human dental pulp cell sheets. J. Photochem. Photobiol. BBiol. 2019, 194, 149-157. [CrossRef]

191. Yurtsever, M.C.; Kiremitci, A.; Gumusderelioglu, M. Dopaminergic induction of human dental pulp stem cells by photobiomodulation: Comparison of $660 \mathrm{~nm}$ laser light and polychromatic light in the nir. J. Photochem. Photobiol. BBiol. 2020, 204, 111742. [CrossRef]

192. Wang, L.; Wu, F.; Liu, C.; Song, Y.; Guo, J.; Yang, Y.; Qiu, Y. Low-level laser irradiation modulates the proliferation and the osteogenic differentiation of bone marrow mesenchymal stem cells under healthy and inflammatory condition. Lasers Med. Sci. 2019, 34, 169-178. [CrossRef]

193. Peat, F.J.; Colbath, A.C.; Bentsen, L.M.; Goodrich, L.R.; King, M.R. In Vitro Effects of High-Intensity Laser Photobiomodulation on Equine Bone Marrow-Derived Mesenchymal Stem Cell Viability and Cytokine Expression. Photomed. Laser Surg. 2018, 36, 83-91. [CrossRef] 
194. Anwer, A.G.; Gosnell, M.E.; Perinchery, S.M.; Inglis, D.W.; Goldys, E.M. Visible 532 nm laser irradiation of human adipose tissue-derived stem cells: Effect on proliferation rates, mitochondria membrane potential and autofluorescence. Lasers Surg. Med. 2012, 44, 769-778. [CrossRef] [PubMed]

195. Constantin, A.; Dumitrescu, M.; Mihai Corotchi, M.C.; Jianu, D.; Simionescu, M. $\mathrm{CO}_{2}$ laser increases the regenerative capacity of human adipose-derived stem cells by a mechanism involving the redox state and enhanced secretion of pro-angiogenic molecules. Lasers Med. Sci. 2017, 32, 117-127. [CrossRef] [PubMed]

196. Iwata, T.; Yamato, M.; Washio, K.; Yoshida, T.; Tsumanuma, Y.; Yamada, A.; Onizuka, S.; Izumi, Y.; Ando, T.; Okano, T.; et al. Periodontal regeneration with autologous periodontal ligament-derived cell sheets- A safety and efficacy study in ten patients. Regen 2018, 9, 38-44.

Publisher's Note: MDPI stays neutral with regard to jurisdictional claims in published maps and institutional affiliations.

(C) 2020 by the authors. Licensee MDPI, Basel, Switzerland. This article is an open access article distributed under the terms and conditions of the Creative Commons Attribution (CC BY) license (http://creativecommons.org/licenses/by/4.0/). 